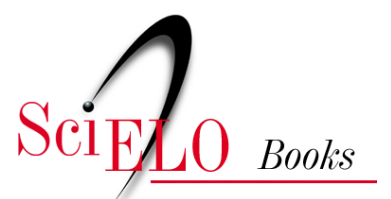

\title{
O homem e a serpente outras histórias para a loucura e a psiquiatria
}

\author{
Paulo Duarte de Carvalho Amarante
}

AMARANTE, P.D.C. O homem e a serpente: outras histórias para a loucura e a psiquiatria [online]. Rio de Janeiro: Editora FIOCRUZ, 1996, 142 p. ISBN 978-85-7541-327-2. https://doi.org/10.7476/9788575413272.

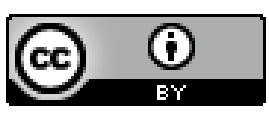

All the contents of this work, except where otherwise noted, is licensed under a Creative Commons Attribution 4.0 International license.

Todo o conteúdo deste trabalho, exceto quando houver ressalva, é publicado sob a licença Creative Commons Atribição 4.0. 


\section{O HOMEM E A SERPENTE}

Outras Histórias para a Loucura e a Psiquiatria 


\section{FUNDAÇÃO OSWALDO CRUZ}

Presidente

Paulo Gadelha

Vice-Presidente de Ensino, Informação e Comunicação

Maria do Carmo Leal

\section{EDITORA FIOCRUZ}

Diretora

Maria do Carmo Leal

Editor Executivo

João Carlos Canossa Mendes

Editores Científicos

Nisia Trindade Lima e Ricardo Ventura Santos

Conselho Editorial

Ana Lúcia Teles Rabello

Armando de Oliveira Schubach

Carlos E. A. Coimbra Jr.

Gerson Oliveira Penna

Gilberto Hochman

Joseli Lannes Vieira

Lígia Vieira da Silva

Maria Cecília de Souza Minayo 
Paulo Duarte de Carvalho Amarante

\section{O HOMEM E A SERPENTE}

Outras Histórias para a Loucura e a Psiquiatria

4" Reimpressão

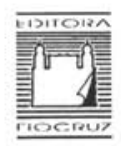


Copyright(C) 1996 do autor

Todos os direitos desta edição reservados à

Fundação OSWALdo CRUz / Editora

ISBN: $85-85676-89-2$

1a edição: 1996

1ำ reimpressão revista: 2000

2 a reimpressão: 2003

3a reimpressão: 2008

4⿳亠口了 reimpressão: 2010

Capa e ilustração: Ruben Fernandes

Projeto gráfico e editoração eletrônica: Mara Lemos

Revisão e preparaçāo de originais: Marcionílio Cavalcanti de Paiva

Colaboraram na $1^{\underline{a}}$ reimpressão

Projeto gráfico e editoração eletrônica: Angélica Mello

Revisão de provas: Claudia Cristiane Lessa Dias

Catalogação na fonte

Centro de Informação Científica e Tecnológica

Biblioteca Lincoln de Freitas Filho

Amarante, Paulo Duarte de Carvalho

O homem e a serpente: outras histórias para a loucura e a

psiquiatria. / Paulo Duarte de Carvalho Amarante. - Rio de Janeiro:

Editora Fiocruz, 1996.

$142 \mathrm{p}$.

1. Hospitais psiquiátricos. 2. Fechamento de instituições de saúde. 3 .

Psiquiatria comunitária - tendências. 4. Saúde mental. 5. Desinstitucionalização I. Título.

2010

EDITORA FIOCRUZ

Av. Brasil, 4036 - Térreo - sala 112 - Manguinhos

21040-361 - Rio de Janeiro - RJ

Tels: (21) 3882-9039 e 3882-9041

Telefax: (21) 3882-9006

e-mail: editora@fiocruz.br

http://www.fiocruz.br 
Dedico este trabalho aos meus pais, Duarte e Olga, a meus irmãos Fausto, Vergínia, Teresa e Preta, aus sobrinhos Paulão, Diogo, Tammara e Lívia, e sobretudo à Cris, ao Felippe e ao Bruno que, pelo amor e carinho com que me suportaram nesta aventura, ficando quase tão loucos quanto eu, me fizeram entender ainda mais o valor do caos e da desordem.

À memória do querido primo César Federici. 

Não the bastava ter descoberto a teoria verdadeira da loucura; não o contentava ter estabelecido em Itaguaí o reinado da razão. Plus ultra! Não ficou alegre, ficou preocupado, cogitativo; alguma cousa lhe dizia que a teoria nova tinha, em si mesma, outra e novíssima teoria.

Vejamos, pensava ele; vejamos se chego enfim à última verdade. (Machado de Assis, O Alienista) 



\section{Sumário}

PREFÁCIO - Franca Ongaro Basaglia 11

\section{APRESENTAÇÃO}

O movimento pela reforma psiquiátrica no Brasil ...................................... 13

A desinstitucionalização como desospitalização .......................................... 15

A desinstitucionalização como desassistência .............................................. 18

A desinstitucionalização como desconstrução ............................................ 20

\section{CAPÍTULO 1}

\section{COMPLEXIDADE E INVENÇÃO}

Outras histórias para a loucura e a psiquiatria ……....................................... 27

Psiquiatria moderna: objeto e processo cognitivo ................................. 32

\section{CAPÍTULO 2}

\section{O PARADIGMA PSIQUIÁTRICO}

Simplificar para conhecer (ou de como a humanidade ganhou uma casa de orates) ........................................................... 37

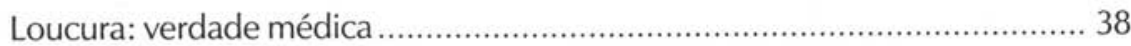

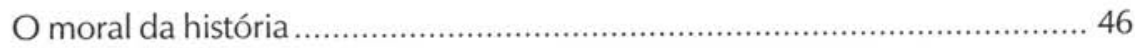

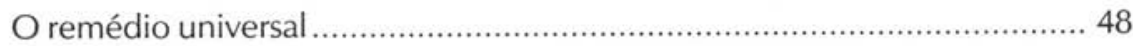

O desvio maléfico e a torrente de loucos ................................................... 53

Do alienismo à psiquiatria contemporânea: alienação, degeneração

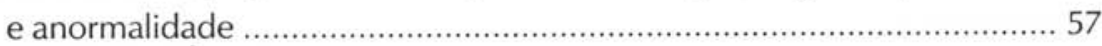

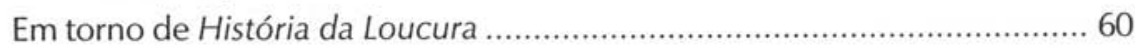

\section{CAPÍTULO 3}

\section{FRANCO BASAGLIA: NOVAS HISTÓRIAS PARA A DESINSTITUCIONALIZAÇÃO}

Uma aventura no manicômio: o homem e a serpente ................................ 65

A renúncia à vocação terapêutica: a instituição negada ............................... 68

Uma importante inversão: a doença mental entre parênteses ................... 77

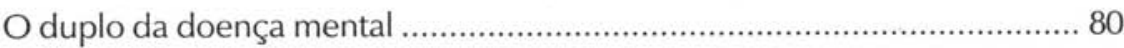


A desinstitucionalização como estratégia para a instituição inventada.......... 83

A cidade: o reencontro com a loucura ..................................................... 95

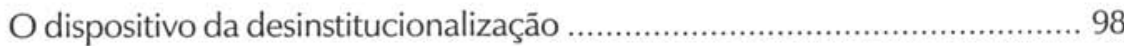

CAPÍTULO 4

\section{A TÍTULO DE PROSSEGUIMENTO}

Psiquiatrismo e formulação de interesses

Reforma psiquiátrica: a utopia antimanicomial e a ética

da desinstitucionalização

\section{ANEXO 1}

Conselhos moraes para a conduta da vida

\section{ANEXO 2}

Franco Basaglia: pequena biografia de um ideal de vida 


\section{Prefácio}

Na Itália, há quase 20 anos da emanação da lei da reforma psiquiátrica, finalmente o governo prevê o fechamento completo dos manicômios até o fim de 1996.

Durante esses anos as resistências foram fortes, e o clima político-social cada vez mais hostil. Mas muitas 'práticas', muitas experiências - mesmo se muito heterogêneas entre si-estavam e estão testemunhando que a mudança cultural e institucional é possível.

Isso traz à tona um dos nós problemáticos do pensamento e da ação de Franco Basaglia: a 'primazia da prática', da qual se pode ler o porquê da sobrevivência dessa nossa batalha, mesmo nos tempos nos quais se fecharam ainda mais os espaços de expressão, tanto do sujeito individual quanto daquele coletivo. Primazia de uma prática entendida não apenas como mero 'fazer', mas como produtora de uma outra realidade e de uma outra cultura, tendo que lidar, seja com o preconceito social para com o doente mental, seja com o preconceito científico para com a doença.

Não se tratou de uma simples mudança de teoria, substituível com uma nova ideologia de recâmbio, mas da demolição concreta de uma cultura, possível somente se, contemporaneamente, outras culturas pudessem ser construídas: outra sustentação, outro suporte, outro conceito de saúde e de doença, de normalidade e de loucura.

Possivel no sentido de que, se junto com o desmantelamento dos velhos hospitais, não se ficasse limitado a organizar simples serviços ambulatoriais; mas se criou, para os velhos e novos doentes, a possibilidade de viver de maneira diversa o próprio sofrimento, visto como o produto de um conjunto de fatores e não apenas como sinal de periculosidade social a reprimir.

A esse sofrimento, que se revela cada vez mais complexo e ao mesmo tempo mais simples, ocorre responder com estruturas e serviços que consintam formas de cura e de assistência que sejam conjuntamente espaços de vida, de estímulo, de confronto, de oportunidades, de relações interpessoais e coletivas diferentes, que vislumbrem uma mudança de cultura e de política mais social que sanitária.

O manicômio está ainda presente: todavia faltam serviços e estruturas adequadas; a qualidade de intervenção é muitas vezes decadente e insuficiente, muitos familiares denunciam o fato de ter que arcar, muitas vezes sem auxílio ou com pouco apoio, com o peso do parente doente. Mas ninguém quer mais o manicômio. Mesmo que 
novos desafios nos esperem ao enfrentar o 'fazer-se instituição' na cotidianidade de nossa vida, mesmo se o risco do transformismo, de uma mudança formal das etiquetas sobre as velhas instituições seja um perigo real, a cultura da exclusão total - do delegar às paredes, às chaves, aos portões, à violência gratuita e desumana passada pela terapia - está vencida. E não somente na Itália.

As experiências de luta contra o manicômio no Brasil, como em outros países do mundo, são um testemunho. Como é um testemunho este livro que, no âmbito de uma reconstrução dos momentos salientes da história da psiquiatria, segue a evolução da experiência italiana como ponto de referência às práticas de mudanças em cena no Brasil.

Franca Basaglia Veneza, abril de 1996 


\section{Apresentação}

\section{O Movimento pela Reforma Psiquiátrica no Brasil}

Este livro visa organizar e atualizar uma série de incursões que tenho realizado em ensaios, resenhas, pesquisas e livros, cujo escopo tem sido a reflexão sobre as bases teóricas e as práticas da reforma psiquiátrica no Brasil em sua relação com a trajetória de Franco Basaglia.

Nos últimos anos, o campo da saúde mental tem sido fortemente marcado pelo debate em torno do que se tem denominado de reforma psiquiátrica. Vale dizer que, desde o surgimento da psiquiatria como disciplina específica, se pensa e se fala em 'reforma da psiquiatria', embora sob outros títulos, sob outras concepções.' Contudo, é sobretudo após a Segunda Grande Guerra que tais iniciativas se intensificam, dando origem a projetos mais delimitados, no sentido de um conjunto de enunciados, propostas e arranjos de natureza técnica e administrativa sobre o campo disciplinar e de intervenção da psiquiatria que, assim, passam a ser explicitamente denominados de reformas psiquiátricas.

Nos últimos anos da década de 70, forma-se no Brasil o Movimento dos TrabaIhadores em Saúde Mental (MTSM), que passa a protagonizar os anseios e as iniciativas pela reforma da assistência psiquiátrica nacional. ${ }^{2}$ No seu início, o MTSM busca uma transformação genérica da assistência psiquiátrica, cujos indícios podem ser encontrados, seja nas denúncias ao modelo oficial - de caráter predominantemente privatizante e 'hospitalocêntrico' -, seja na elaboração de 'alternativas' inspiradas basicamente em propostas de desospitalização.

De forma distinta das propostas anteriores, predominantes na década de 60, que objetivavam transformações de caráter exclusivamente técnico, o projeto do MTSM assume um caráter marcado pela crítica ao saber psiquiátrico que, a partir de então,

1 Rigorosamente, o modelo de colônias de alienados pode ser considerado um projeto de reforma psiquiátrica, levado a cabo em meados do século XIX, especialmente na França, Alemanha, Itália e Inglaterra e no Brasil, em fins do século XIX até meados do século XX (AMArante, 1982). A literatura psiquiátrica é repleta de outros exemplos.

2 A esse respeito organizei um conjunto de documentos originais e projetos do MTSM, desde 1978

- data de sua constituição - até 1987 - data de sua transformação no Movimento por uma Sociedade sem Manicômios (Amarante, 1990b). 
vem delineando o surgimento da atual concepção de reforma psiquiátrica. Esta vem configurar um processo bastante inovador, original e prolífero, permeado por inúmeras iniciativas práticas de transformação, com o surgimento de novos atores e protagonistas e uma emergente produção teórica, na qual novas questões surgem no cenário do campo da saúde mental.

Com base nessa constatação, deu-se início a uma pesquisa que tinha como objetivo refletir sobre a trajetória do movimento, procurando responder a algumas questões, a exemplo de como, de que forma, em que contextos, sob a condução de que atores e sob que pressupostos surgem os projetos e os processos de transformação da assistência psiquiátrica no Brasil. $^{3}$

No entender de (Birman, 1992:71), o Movimento pela Reforma Psiquiátrica expressa "uma maior maturidade teórica a política", a qual pode ser entendida como delimitação mais clara do projeto das transformaçōes em psiquiatria, que transcendem à busca de soluções exclusivamente técnicas ou administrativas, para remontarem a questōes a um só tempo teóricas, políticas, culturais e sociais. Nesse novo cenário, o conceito de cidadania é, pois, palavra-chave fundamental, na medida em que percorre os níveis anteriores e que, em razão da natureza do estatuto de alienação mental, ao louco é subtraída a possibilidade de inscrição no mundo da cidadania, no espaço da cidade, no mundo dos direitos.

Essa maturidade teórica e política é conseqüência de um deslizamento,

de maneira decisiva, do debate técnico e político sobre as distorções, os abusos e a violência presentes na assistência psiquiátrica brasileira, para nos indagarmos sobre um problema mais fundamental, pois perpassa como uma invariante o universo caótico dos cuidados: a condição de cidadania dos doentes mentais. (Birman, 1992:71-72)

No entanto, os projetos de reforma não podem ser tomados em conjunto, isto é, não são homogêneos, no sentido dessa maior maturidade. Muito embora exista 'atualmente' uma hegemonia dessa tendência apontada por Birman, os conceitos e as

3 Trata-se da pesquisa Análise dos Determinantes e Estratégias das Políticas de Saúde Mental no Brasil: o projeto da reforma psiquiátrica (1970-1990) (AMArante, 1993), desenvolvida no Nupes/Daps/Ensp/ Fiocruz, no período de 1989 a 1993, e publicada sob o título Loucos pela Vida: a trajetória da reforma psiquiátrica no Brasil (AMARANTE, 1995; segunda edição em 1998), como parte de uma pesquisa maior sobre a reforma sanitária no Brasil (TeixeırA, 1989). 
práticas quanto à reforma psiquiátrica são muito diversos entre os atores que a exercitam. A luta pela cidadania dos doentes mentais, embora seja um aspecto extremamente importante, não é delimitador exclusivo dessas tendências.

No contexto atual de consolidação democrática no País, a luta pela cidadania é uma luta geral, compartilhada por amplos setores da sociedade civil, tomada a partir de várias questões - a cidadania das mulheres, crianças, negros, povos da floresta, dentre outras -, embora tenha características e especificidades quanto ao doente mental. De fato, pelas peculiaridades cientificamente estabelecidas quanto à categoria 'doença mental', o doente é despojado de seus direitos jurídicos, políticos e civis, tornando-se, dessa maneira, um não-cidadão.

À parte a sua enorme importância, contudo, a questão da cidadania não é objeto deste estudo, mesmo porque muitas produções recentes têm-se dedicado ao tema, como aquela anteriormente mencionada. O que efetivamente demarca uma real distinção entre os projetos de reforma, e por isso é o alvo maior deste livro, é a forma do lidar prático e teórico da desinstitucionalização, conceito este que sofre metamorfose substancial e que abre novas possibilidades para o campo da reforma psiquiátrica.

\section{A desinstitucionalização como desospitalização}

A noção de desinstitucionalização surge nos EUA em decorrência do Plano de Saúde Mental do Governo Kennedy, entendida basicamente como um conjunto de medidas de desospitalização. Lougon (1993:142) alinha seus princípios fundamentais, reproduzidos do Diretor do Instituto Nacional de Saúde Mental dos EUA:

1. a prevenção de internaçōes inadequadas em instituições psiquiátricas, procurando alternativas comunitárias para o seu tratamento;

2. retorno para a comunidade de todos os pacientes institucionalizados que tiveram preparo adequado para tal mudança;

3. o estabelecimento e a manutenção de sistemas de suporte comunitário para as pessoas não-institucionalizadas que estejam recebendo serviços de saúde mental na comunidade. ${ }^{4}$

$4 \quad$ O citado artigo é de Brown (1975). 
Essa formulação da desinstitucionalização, nascida dos projetos de psiquiatria preventiva e comunitária, opera uma crítica ao sistema psiquiátrico, por ser centrado na assistência hospitalar, mas não faz o mesmo com a natureza do saber que o autoriza. Em resumo, inspira-se no paradigma psiquiátrico tradicional, assumindo a validade de seus princípios, e partindo do pressuposto de que a reforma implica a correta aplicação do saber e das técnicas psiquiátricas, ou seu simples rearranjo e condução administrativa. A causa da falência do sistema psiquiátrico não estaria na psiquiatria, mas na má aplicação desta.

Na organização prática do sistema psiquiátrico, as reformas de base preventiva e comunitária consistem, por um lado, em medidas saneadoras e racionalizadoras, tais como na diminuição de leitos e de tempos médios de permanência hospitalar, no aumento do número de altas ou na criação de serviços intermediários. $\mathrm{E}$, por outro, na implantação de uma rede de serviços e ações de cunho sanitário, preventivo/promocional e comunitário que intercederiam no surgimento ou desenvolvimento das doenças. Dessa forma, o que se considera 'intermediário' tem dois sentidos: o primeiro, é no sentido de 'passagem' entre o hospital e a comunidade ou vice-versa (isto é, quando o paciente transita pelo serviço em processo de saída hospitalar, em processo de readaptação social, ou quando por tentativa de evitar a internação integral e imediata); o segundo, é no sentido de 'provisório', isto é, como modalidade assistencial que deveria existir até o momento em que o hospital tornar-se-ia obsoleto, dada a implantação da rede de serviços preventivos e comunitários.

Embora calcada em uma crítica conceitual ao modelo da organização psiquiátrica, a desinstitucionalização nessa tradição está voltada, sobretudo, para objetivos administrativos (redução dos custos da assistência para os cofres públicos), e menos para uma real transformação da natureza da assistência. No entanto, o hospital psiquiátrico, ou como preferimos denominá-lo, o manicômio, também não é colocado em questão. ${ }^{5}$ Entende-se apenas que o manicômio não deva ser de grande porte e que, com a implantação das medidas saneadoras e racionalizadoras, torna-se-ia, inexoravelmente, um recurso obsoleto. Na prática, esses planos não têm sido tão menos onerosos quanto se esperava, ao mesmo tempo em que a rede de serviços intermediários tem servido mais para aumentar a demanda hospitalar do que para desativar os manicômios.

5 A expressão manicômio, em substituição a hospital psiquiátrico, tem sido utilizada mais especificamente desde 1987, como uma estratégia do MTSM no sentido de reforçar o caráter asilar, segregante, violento, tutelar e médico-jurídico de todas as instituiçōes desta ordem. Conceitualmente, pois, para o MTSM, não há distinção entre hospital psiquiátrico, clínica psiquiátrica, asilo, manicômio ou hospício (AMARanTE, 1990b). 
Embora nascida como crítica à aplicação do modelo psiquiátrici), a desinstitucionalização, nessa versão, propicia uma ampliação do território psiquiátrico, ${ }^{\circ}$ isto é, alarga o conceito de doença para o de desvio, mal-estar social, desajustamento, anormalidade. Com isso, produz-se um efeito rebote, pois criam-se inúmeros novos serviços, especialidades e técnicas que, em uma palavra, aumentam o número de pessoas assistidas e as possibilidades de intervenção técnica, sem que os resultados terapèuticos sejam correspondentes. ${ }^{7}$ Assim, torna-se possível ainda verificar como esses têm-se tornado obstáculo à possibilidade de transformações mais substanciais. Ao contrário, o preventivismo tem sido importante referencial teórico para uma inédita estratégia de patologização e normalização do social, fornecendo novas tecnologias e referências para a inscrição do sofrimento psíquico e do mal-estar social no rol das patologias.

Para o preventivismo há uma inversão do modelo psiquiátrico, voltado sobretudo para a cura e a reabilitação, isto é, para a predominância das atividades assistenciais, enquanto as prioridades deveriam ser as de prevenção e promoção da saúde mental. O saber e as práticas psiquiátricas operadas nesse modelo seriam exatamente as mesmas da psiquiatria tradicional, sendo simplesmente adequadas aos novos propósitos. Em resumo, numa análise de maior profundidade, trata-se do mesmo projeto tradicional que aspira ora sua revivescência, ora sua 'atualização', no sentido do aggiornamento, tal como proposto por Castel (1978a).

Enquanto vigorosa referência epistemológica de alguns projetos de reforma psiquiátrica, o preventivismo aponta para transformações assistenciais e administrativas, sem deter-se no questionamento do arcabouço teórico com o qual a psiquiatria apreende o fenômeno da loucura ou, ainda, na forma como constrói sua vocação terapêutica. Ao contrário, reporta à psiquiatria um campo epistêmico que delineia o 'ideal da saúde mental', o que significa dizer que, ao vislumbrar para além do tratamento ou da cura das doenças mentais, aspectos por si sós absolutamente polêmicos, edifica o ideal da ausência das doenças mentais no meio social. ${ }^{8}$ Essa operação é teoricamente possível,

6 "Quanto à idéia de ampliar o território da loucura, achou-a o boticário extravagante..." (O Alienista, p.27-28). Esta crônica de Machado de Assis é uma das mais profundas a criativas obras críticas sobre a ciência e a psiquiatria, extremamente útil a adequada para o conceito de

desinstitucionalização que, aqui, procuro desenvolver. Uma belíssima leitura da crítica machadiana à ciência e à psiquiatria é realizada por Murıcr (1988).

7. A esse respeito, ver Costa (1980) e Castel (1987).

B Muito embora o campo prático-teórico da assistência psiquiátrica, bem como suas implicaçōes com os aspectos sociais, políticos, ideológicos, culturais, tem sido denominado genericamente 'saúde mental', no sentido de estabelecer suas relaçōes com os campos da saúde pública e saúde coletiva, é oportuno lembrar que o ideal da saúde mental é uma construção decorrente da psiquiatria preventiva, base da psiquiatria social contemporânea. A esse respeito, consultar Birman \& Costa (1994). 
na medida em que a psiquiatria preventiva fundamenta-se numa 'história natural das d'st'n as' Leavell \& Clark, 1976) na qual, entende-se, seja possível intervir em diferentes étâpas do processo de patologização, evitando assim sua conformação ou o seu desenvolvimento.

De fato, quando se fala em reforma psiquiátrica, não se está falando, necessariamente, na superação do paradigma fundante da psiquiatria, nem na negação de seu mandato social, mas em transformações mais ou menos superficiais, administrativas, organizativas e modernizantes do aparato prático-discursivo. Considera-se, muitas das vezes, que a questão não está na ordem do saber psiquiátrico mas, como vimos, na sua operacionalidade prática, e que bastaria reorganizar os recursos, administrá-los adequadamente, dispô-los corretamente, para se alcançar um bom resultado preventivo e terapêutico.

Assim, pois, se apresenta a psiquiatria preventiva, que não entra no campo específico do saber psiquiátrico sobre as doenças mentais, mas, tão-somente, propõe uma nova engenharia de recursos e serviços. Grosso modo, podem ser assim consideradas as propostas de reformas de cunho sanitarista, com suas estratégias de hierarquização, simplificação, participação comunitária, regionalização que, em última instância, utilizam-se também do substrato teórico do preventivismo.

Correndo o risco de ser inconveniente, deve-se insistir no aspecto de que, com tamanha pretensão, a psiquiatria preventiva torna-se referencial muito forte no campo psiquiátrico, influenciando, desde o seu surgimento, inúmeros projetos de reforma psiquiátrica, pois, em última instância, todos parecem ser favoráveis à prevenção ou à utopia de uma sociedade sem mal-estar ou doenças. As bases conceituais da psiquiatria preventiva informam, ainda, um significativo número de projetos de reforma no Brasil, o que vem justificar uma reflexão específica sobre seus princípios e estratégias.

\section{A desinstitucionalização como desassistência}

Uma outra tendência verificável nesse processo de reforma coloca-se em oposição à desinstitucionalização, por entendê-la como mera desospitalização ou, na radicalidade, como simples desassistência, isto é, como se as políticas de desinstitucionalização não significassem a substituição do modelo hospitalar por outras modalidades de assistência e cuidado. Entende-se, nesse sentido, que a 
desinstitucionalização significaria abandonar os doentes à própria sorte, seja pela premissa crítica, correta, de que seu objetivo pode ser o de reduzir ou erradicar a responsabilidade do Estado para com essas pessoas e familiares, seja por uma compreensão pouco correta do conteúdo teórico que está em jogo.

Evidentemente, a desinstitucionalização, como se pretende abordar, não pode, em absoluto, representar o 'desamparo' dos doentes ou o simples "envio para fora do hospital, sem ser implantada, antes, uma infra-estrutura na comunidade para tratar e cuidar dos mesmos e das suas famílias", como querem fazer entender Morgado \& Lima (1994:21-22).

Nessa mesma ordem, por descuido ou má-fé, colocam-se todos aqueles que se opõem à desinstitucionalização. Aqui podem ser encontrados determinados segmentos atavicamente conservadores que, efetivamente, resistem a toda e qualquer idéia que represente ampliação dos direitos e igualdade aos setores considerados minoritários, seja por credo, raça, cor, doença ou condição social. Podem ser achados, ainda, aqueles que têm interesses específicos na organização atual da psiquiatria e suas extensões, para os quais a simples menção do termo desinstitucionalização faz tremer esses mesmos interesses.

Essa tendência contradesinstitucionalizante assume maior significado após o surgimento do projeto de lei $n^{2} 3.657 / 89 .{ }^{9}$ Para além da questão do saber psiquiátrico, de sua cientificidade ou funcionalidade, é certo que se organizam interesses muito específicos de empresas e grupos que vivem na dependência do êxito desses mesmos interesses. Assim comportam-se, por exemplo, a indústria farmacêutica, a corporação psiquiátrica e, mais especificamente, em nosso contexto, os empresários de hospitais psiquiátricos. ${ }^{10}$ Estes, muitas das vezes, não sabem ou não pretendem saber o que significa a desinstitucionalização; contudo, opõem-se a ela pelo risco que pode representar aos seus interesses constituídos, e tão-somente sobre estes seus argumentos são construídos.

$9 \quad$ Projeto de lei de autoria do deputado Paulo Delgado, que propōe a progressiva extinção dos hospitais psiquiátricos e sua substituição por outras modalidades de assistência. O projeto não tem apenas esse resultado, isto é, a organizaçāo dos setores a ele contrários: na trajetória do movimento pela reforma psiquiátrica no Brasil, significa um marco político da maior importância, ao possibilitar ampliação, até então inédita, do debate público sobre a loucura, a doença mental, a psiquiatria e suas instituiçōes, inclusive com expressiva participação da grande imprensa. No entanto, desencadeia o surgimento de outros projetos análogos, dentre os quais alguns já aprovados.

10 Cumpre assinalar que, nos projetos de desinstitucionalização decorrentes das versōes anteriores, a indústria farmacêutica geralmente tende a oferecer apoio, uma vez que a expansão do território psiquiátrico pode significar aumento de situações consideradas patológicas e, conseqüentemente, aumento do consumo de medicamentos. 
Por tal motivo abordam a desinstitucionalização de forma propositalmente deturpada, procurando associá-la à desassistência e ao desamparo, mas num contexto diverso daquele imediatamente anterior. ${ }^{11}$

\section{A desinstitucionalização como desconstrução}

Uma outra tendência, que é sobre a qual Birman faz referência, e na qual também o Movimento pela Reforma Psiquiátrica brasileira busca inspiração, pode ser caracterizada pela predominância da crítica epistemológica ao saber médico constituinte da psiquiatria, onde inclusive a cidadania ultrapassa o sentido do valor universal para colocar em questão o próprio conceito de doença mental que determina limites aos direitos dos cidadãos.

Um aspecto comum, que poderia aproximar as várias experiências, contribuições e projetos dessa tendência de reforma psiquiátrica, é a identificação com a trajetória prático-teórica da tradição desenvolvida par Franco Basaglia, cuja principal referência está no conceito de desinstitucionalização que, a partir daqui, consolida um novo significado. ${ }^{12}$

Em fins dos anos 70, as reflexões de Basaglia estão bastante presentes em nosso meio, resultado, até mesmo, de algumas vindas suas ao Brasil, mantendo contatos diretos com o então recém-criado MTSM. ${ }^{13} \mathrm{O}$ interesse por Basaglia era decorrente de muitos aspectos, dentre os quais a repercussão internacional quanto à desativação do hospital de Gorizia, a sua decisiva participação na criação dos movimentos Psiquiatria Democrática e Rede Alternativas à Psiquiatria e, ainda, e um tanto posteriormente, a promulgação na Itália da Lei n²180, de 1978, que ficou conhecida como a Lei Basaglia. ${ }^{14}$

Mas em conseqüência do caráter fortemente político de suas idéias e propostas, por sua crítica vigorosa ao saber psiquiátrico, pelo questionamento da função social cumprida pelos técnicos e pela tecnociência, extremamente adequados ao perfil dos

\footnotetext{
1 Como exemplo dessa linha, confira a argumentação de RıBEıro (1993).

12 Quanto ao aspecto da desinstitucionalização como desconstrução, é necessário adiantar que, paralelamente à Basaglia, o movimento da antipsiquiatria também traz importantes contribuições nesse sentido.

13 A esse respeito, ver Roteut \& AMARANTE (1992).

14 Também a respeito da Lei $\mathrm{n}^{\circ} 180$ podem ser consultados Rotel. \& AMARANTE (1992) e, ainda, Rotelu (1992), Nić́cio (1989) e Barros (1994). O texto da lei, na íntegra, está traduzido em Delcado (1991).
} 
movimentos sociais nesse período da redemocratização, o MTSM é substancialmente marcado pela démarche percorrida por Basaglia.

Por uma série de aspectos que não são objeto deste estudo, o MTSM afasta-se consideravelmente das contribuições propiciadas por Basaglia, mas que retornam, com muito vigor, a partir dos últimos anos da década de $80 .^{15}$ Esse retorno pode ser facilmente verificado, seja pelo exame da natureza de um grande número de experiências que ora se desenvolvem, inclusive os projetos de lei anteriormente referidos, seja pela crescente produção teórica que trata dessas contribuições.

É importante ainda destacar que a partir daí o movimento brasileiro tende a abandonar sua especificidade, de movimento de 'trabalhadores em saúde mental', para procurar tornar-se um movimento 'social' pela reforma psiquiátrica. Exemplo dessa iniciativa é a estratégia 'por uma sociedade sem manicômios', que reflete a tendência para comprometer a sociedade, em geral, no domínio do processo de desinstitucionalização. De modo diverso dos lemas preventivistas - 'saúde para todos no ano 2000', ou do 'ideal da saúde mental' -, estabelece estratégias mediatas, tais como a luta pela extinção/superação das instituições da violência, que traduzem um processo prático de 'construção' de uma nova realidade em torno da loucura a da psiquiatria. Tais estratégias implicam o reconhecimento de que, se a realidade é essencialmente construída, pode ser substancialmente modificada.

Assim, se essa tendência do Movimento pela Reforma Psiquiátrica não perde por completo o approach crítico, 'em parte' isso pode ser atribuído à marcante influência que Franco Basaglia teve, em sua origem, e na reconstrução do conceito de desinstitucionalizaçăo. Se comparado com o Movimento pela Reforma Sanitária, o movimento no campo psiquiátrico parece poder ir bem mais longe, no sentido das transformações mais propriamente qualitativas no âmbito do modelo de saúde que se implementa. O Movimento pela Reforma Sanitária, originalmente maturado sob uma perspectiva crítica quanto à natureza do saber médico, em campos então denominados de medicina social e saúde coletiva, destes vai-se afastando de forma bastante visível.

15 Desenvolvo algumas das razōes desse afastamento em Amarante (1990a). Cumpre destacar que o ressurgimento do interesse às contribuições de Basaglia e da experiência triestina, por ele iniciada, não ocorre apenas no Brasil. Em muitos outros países tem ocorrido o mesmo, inclusive com reedição de seus trabalhos mais importantes (MOSHER \& BURTI, 1991; SHEPER-HUCHes \& LOVELL 1987). Porém, desde o reconhecimento do serviço de Trieste, pela Organizaçăo Mundial da Saúde (OMS), como centro de referência, o mesmo vem prestando consultoria em muitos países da Europa, Ásia e Américas. Cf. Rotelu \& Amarante (1992). Finalmente, o próprio desenvolvimento deste serviço, a partir da segunda metade da década de 80 , vem justificar o aumento de interesse sobre seu processo de desinstitucionalização (DE Leonardis, MAURI \& ROteLL, 1994). 
Como resultado desse afastamento, a reforma sanitária vai-se tornando um conjunto de medidas predominantemente administrativas, das instituições assistenciais do setor saúde, sem o questionamento do modelo médico de análise e terapêutica, ou das conseqüências imediatamente derivadas da natureza mesma desse modelo, tais como a 'escuta' e a abordagem exclusivamente técnicas do sintoma/mal-estar, a tendência ao especialismo radical, a produção de uma cultura medicalizante, o desmesurado intervencionismo diagnóstico e terapêutico, e a formulação de interesses do complexo médico-industrial aí envolvido. O especialismo, a cultura hospitalocêntrica da medicina moderna, a divisão do homem em órgãos, sistemas etc., não são desvios desse modelo, mas a sua própria essência. Em suma, a questão entre os movimentos pelas reformas psiquiátrica e sanitária está na relação com a qual um e outro mantém com o saber constituinte de seus campos específicos. Eis porque um dos objetivos deste livro é o de analisar em que medida as contribuiçōes de Basaglia vêm oferecer à psiquiatria uma ruptura prático-teórica, que, assim entendida, pode servir de substrato para o surgimento de novas histórias e questões epistemológicas para a reforma psiquiátrica.

Procura-se desenvolver a hipótese de que a produção de Basaglia pode ser entendida como importante marco de referimento de uma 'fase de transição' do paradigma psiquiátrico-moderno, a qual se situa em uma transição maior - a da ciência da modernidade. Para Santos, tal 'fase' se traduz no que é "a ambigüidade e a complexidade da situação do tempo presente, um tempo de transição, síncrone com muita coisa que está além ou aquém dele, mas descompassado em relação a tudo o que o habita" (Santos, 1987:6). ${ }^{16}$ Se essa é uma 'fase de transição', não se sabe ainda o que está por vir; e, como anunciava Basaglia (1985:10), ${ }^{17}$ "e não sabemos qual será o próximo passo", porque essa não é uma realidade estática, em equilíbrio, mas em construção, de invenção prático-teórica, em relação direta e objetiva com a realidade que a cada momento se apresenta e se transforma.

Esse movimento, ou essa incerteza no 'saber o futuro', que muitas vezes tem sido entendido como ponto frágil da experiência de Basaglia é, em resumo, uma importante atitude epistemológica no "lidar com as contradições do real", na qual o pro-

16 Para Santos, as ciências estão num período de transição que, utilizando-se da metáfora do vaso branco recortado sobre o fundo preto, é assim definido: "Qual das imagens é verdadeira? Ambas e nenhuma. É esta a ambigüidade e a complexidade da situação do tempo presente, um tempo de transição, síncrone com muita coisa que está além ou aquém dele, mas descompassado em relação a tudo o que o habita" (SANTOS, 1987:6).

17 Basaclia, Franco et al. (1985). 
jeto de desinstitucionalização volta-se para a superação do ideal de positividade absoluta da ciência moderna em sua racionalidade de causa-efeito, para voltar-se para a 'invenção da realidade' como processo histórico.

Relacionando as contribuiçōes de Basaglia com a produção recente, realizada por autores dessa mesma tradição, à luz ainda da produção sobre a complexidade do ponto de vista neoconstrutivista, procurarei demonstrar que o uso e a forma de utilização de determinados conceitos - que vêm sendo utilizados na área específica da reforma psiquiátrica brasileira, decisivos para as referências desse campo epistemológico emergente, dos quais o conceito de desinstitucionalização é a expressão maior - têm origem nas reflexões de Franco Basaglia. A releitura de suas reflexões, atualizada com base nas questões que se apresentam contemporaneamente no âmbito da história das ciências e da epistemologia da complexidade, é extremamente importante para o redimensionamento do processo atual das reformas psiquiátricas.

Basaglia, mais do que elabora, organiza um corpo teórico e um conjunto de estratégias para lidar com a psiquiatria. Referenciado a partir de amplo leque de abordagens provenientes não apenas dos projetos de reforma psiquiátrica, mas, e fundamentalmente, das chamadas "humanidades" (Santos, 1987:10), ${ }^{18}$ inicia, assim, uma trajetória absolutamente original de desinstitucionalização na psiquiatria. Vale a pena insistir no aspecto de que muitas das questōes que estarão aqui apresentadas, como originadas em Basaglia, são inspiradas em outros autores. ${ }^{19}$

A maior originalidade de Basaglia está na forma de lidar com tais questōes; em parte, no operar o seu transporte para o campo dos estudos sobre a loucura, ou seja, dilatando este campo, ou, em certo sentido, 'desterritorializando-o' dos limites psiquiátricos, mas, e fundamentalmente, em realizar tais operações no universo práticodiscursivo concreto da psiquiatria. De outro modo, Basaglia apreende tais contribuições e as incorpora efetivamente no seu processo prático-teórico de desinstitucionalização.

Como se viu, o surgimento da denominação reforma psiquiátrica, para alguns autores, reflete uma abrangência maior que aquela das décadas anteriores, expressa na ampla literatura recente sobre a instituição psiquiátrica. Mas essa expressão é contradi-

18 Para este autor, as chamadas humanidades ou estudos humanísticos incluem, dentre outros, os estudos históricos, filológicos, jurídicos, literários, filosóficos e teológicos.

19 Na construção de seu projeto, Basaglia apóia-se na obra de muitos autores, dentre os quais destacam-se: Sartre, Hegel, Husserl, Heiddeger, Merleau-Ponty, Binswanger, Gramsci, Althusser, Foucault, Goffman, Adorno, Marcuse, Fromm, Horkheimer, Habermas, Artaud, Parsons, Martin, Maxwell Jones, Tosquelles, Bonnafè, Fanon, Laing e Cooper. 
tória e problemática, uma vez que, per se, não define o quê e o quanto se está reformando. Rotelli (1990:19) reserva a expressão "psiquiatria reformada" para as iniciativas de reforma nas linhas da comunidade terapêutica, da psicoterapia institucional, da psiquiatria de setor ou da psiquiatria preventiva, quanto a caracterizar seus intentos de renovação da capacidade terapêutica da psiquiatria, "liberando-a de suas funções arcaicas de controle social, coação e segregação".

Com base nas contribuições de Basaglia acerca das instituições e dos processos de institucionalização, alguns de seus colaboradores redefinem o conceito de desinstitucionalização. Dentre estes, destacam-se: Rotelli, Dell'Acqua, Venturini, De Leonardis e Mauri, que não apenas ampliam o conceito, mas, sobretudo, introduzem a discussão quanto aos aspectos da crítica epistemológica aos saberes psiquiátricos.

De Leonardis (1987:248) propõe a noção de "psiquiatria da desinstitucionalização" para a 'reforma' na tradição basagliana, tendo em vista que esta designa "um percurso complexo de 'desconstrução a partir do interior da instituição psiquiátrica'", e por ser um processo, ao mesmo tempo prático e teórico, que insere transformações no campo do saber e das instituições.

Por tais motivos estarei referindo-me a essa corrente como tradição basagliana ou como a psiquiatria da desinstitucionalização, muito embora esta última concepção não deixe de ter algumas contradições, uma vez que a trajetória prático-teórica de Basaglia indica um caminho que vai além do campo meramente psiquiátrico.

No entanto, seria inadequado denominá-la simplesmente de psiquiatria italiana, como preferem muitos autores, já que não é adotada em toda a Itália, e nem mesmo hegemônica. Inadequada, ainda, seria a expressão psiquiatria democrática, também utilizada por muitos autores, em referência ao movimento fundado e liderado for Franco Basaglia, mas que não poderia ser plenamente identificado, no aspecto conceitual, com as proposições do seu principal articulador, pois trata-se, mais especificamente, de um movimento político, historicamente datado no contexto italiano.

Existiria, ainda, a possibilidade de denominá-la de psiquiatria territorial, conforme proposto por Mosher \& Burti (1991), que traduz com maior rigor as concepções de algumas das experiências surgidas a partir de Basaglia, mas não o conjunto de seu pensamento e prática.

A produção de Basaglia servirá como referência para a leitura da constituição e do nascimento da psiquiatria, bem como para dos projetos de reforma. Para tanto, torna-se necessário, primeiramente, demarcar a natureza e o arcabouço teórico da 
psiquiatria como disciplina, em uma abordagem que vai de Pinel a Kraepelin, identificando e aprofundando seus conceitos e estratégias para, posteriormente, discuti-los à luz da tradição basagliana.

Espera-se que este livro seja útil àqueles que lidam com os sujeitos dos sofrimentos, das loucuras, das doenças e que buscam melhores formas nesse lidar, no processo que vimos denominando de reforma psiquiátrica. Da mesma forma, deseja-se que o mesmo possa ainda contribuir para as discussões sobre a reconstrução do processo da reforma sanitária, para o qual torna-se premente recolocar a questão do paradigma médico-moderno centrado nessa mesma estratégia de desinstitucionalização. ${ }^{20}$

\section{Agradecimentos}

À direção da Escola Nacional de Saúde Pública (ENSP) e da Fundação Oswaldo Cruz (FıOCRuz); à Coordenação de Aperfeiçoamento de Pessoal de Nível Superior (CAPES), pela oportunidade de realizar a bolsa 'sanduíche' em Trieste, pois foi muito importante para o meu trabalho e para a minha vida; ao Centro de Estudos e Pesquisas de Trieste; ao Conselho Nacional de Desenvolvimento Científico e Tecnológico (CNPq) e à Organización Panamericana de la Salud (OPS), pelo apoio a nossas pesquisas e cursos no Núcleo de Estudos Político-Sociais em Saúde (Nupes) e no Laboratório de Estudos e Pesquisas em Saúde Mental (LAPS), que também em muito contribuíram para este livro; a todos os amigos da ENSP e da FIOCRUZ; aos alunos do Curso de Especialização em Saúde Mental; aos amigos e companheiros da SosINTRA, simbolizando todos os ‘oucos pela vida', que vêm construindo e inventando novas possibilidades de çidadania.

wo Em seu artigo, TESTA (1992) debate algumas idéias semelhantes, atentando para a necessidade de um processo de desinstitucionalização na medicina em geral, no mesmo sentido que ocorre para com a psiquiatria. 
Agradeço, ainda, aos seguintes amigos e professores pelo carinho para comigo e pela colaboração com o meu trabalho: Alberto Chicayban, Alessandra Rosa Santos, Alexandre Magno Teixeira, Anamaria Tambellini, Andréa da Luz Carvalho, Antônio Ivo de Carvalho, Antonio Slavich, Carlos Fernando Reis da Costa, Carlos Osanai, Cecília Coimbra, Cecília Minayo, Cláudia Damasceno, Cláudia Erhenfreund, Cristina Possas, David e Chiquinho da Gráfica, Deborah Uhr, Denise Dias Barros, Edmundo Gallo, Eduardo Stotz, Ernesto Aranha, Ernesto Venturini, Everardo Duarte Nunes, Fernanda Nicácio, Franca Ongaro Basaglia, Francisco Edmilson Carneiro, Francisco Inácio Bastos, Franco Rotelli, Geraldo Luchesi, Giancarlo Carena, Gianni Conti, Giuseppe Dell'Acqua, Jacob Portela, Janete Romeiro Rosa, Jeni Vaitsman, Laurinda Beato, Lenita Xavier, Lenaura Lobato, Ligia Giovanella, Luciene Burlandi, Luis Cavalieri, Luis Cláudio Guimarães da Silva, Madel Luz, Manuel Desviat, Marcionílio Cavalcanti de Paiva, Marco Antônio Porto, Maria do Carmo Leal, Maria Helena Mendonça, Maria Helena Sette Colazos, Marisa Cambraia, Martha Nunes Moreira, Nilson do Rosário Costa, Paolo Tranchina, Paulo Buss, Pedro Teixeira, Pilar Belmonte, Rafaelle Infante, Renato Veras, Ricardo Conde, Ruben Fernandes, Ruth Martins, Selma Lancman, Sergio Goes, Sergio Guerrieri, Silvia Gerschman, Sonia Fleury, Valéria do RADIS, Valéria Lagrange, Vera Portocarrero, Vilma Valéria Fonseca Brito, Waldir da Silva Souza, Walter Duarte e Wilmar do Vale Barbosa. De Romú, a saudade...

Em particular, a Joel Birman e a Franco Rotelli que, ao longo de suas vidas, têm contribuído para o surgimento de muitas outras histórias para a loucura e a psiquiatria, e para a dignidade da vida humana. 


\section{Capítulo 1}

\section{Complexidade e invenção}

\section{Outras histórias para a loucura e a psiquiatria}

O desenvolvimento da epistemologia e da filosofia no campo das ciências reporta à questão do 'conhecer conhecimento', e faz com que muitas histórias tenham que ser repensadas como, dentre essas, a da psiquiatria moderna e suas reformas.

Tal processo, no âmbito epistemológico, constitui um "trânsito" (Ortega y Gasset, 1989) ou uma "fase de transição" (Santos, 1987), enquanto questão que se coloca contemporaneamente em vários universos prático-discursivos, nas áreas da filosofia, da ética, da política a das tecnociências. Ceruti \& Bocchi (1985) denominam esse processo epistemológico de "desafio da complexidade", como um terreno amplo de questōes que dizem respeito às relações entre o conhecimento e o seu objeto, ou entre 'observação' e 'observado'.

Na concepção de Ortega y Gasset, a construção da racionalidade é inerente ao processo de hominização, no qual "toda a ciência de realidade, seja esta corporal ou espiritual, tem de ser uma construção e não um mero espelho dos fatos".

E mais adiante: "A esta arquitetura que o pensamento pōe sobre nosso contorno, interpretando-o, chamamos mundo ou universo. Este, pois, não nos é dado, não está aí, casualmente, mas é fabricado por nossas convicções" (Ortega y Gasset, 1989:31-34).

As relações entre sujeito e objeto epistêmico permitem-nos, portanto, falar de uma "invenção" da realidade (Watzlawick, 1984), o que, no entanto, não torna essa realidade menos real, nem menos importante.

Esse desafio, de recolocar a dimensão das relações entre conhecimento e objeto, que vem sendo definido como construtivismo, epistemologia da construtividade ou, simplesmente, complexidade, surge como conseqüência de uma série de questões emergentes no campo da produção dos saberes que, sobretudo a partir dos anos 70, 
têm como elemento comum a ênfase nos limites do paradigma científico moderno, ou, em outras palavras, coloca em questão a idéia de 'desconstrução' da verdade produzida pelas ciências. ${ }^{21}$

Esse processo, por um lado, implica o reconhecimento da limitação do método científico em conhecer o real, isto é, a constatação de que o saber científico é parcial e restrito per se. Por outro, de que o real é sempre e necessariamente complexo, que tem vários níveis concomitantes de existência, de possibilidades e de compreensão, que não se excluem nem se complementam, mas são, em si, a sua própria complexidade.

Mas é oportuno antecipar dois aspectos. O primeiro refere-se ao fato de que complexidade não é sinônimo de complicação. Stengers (1989:150-154) demonstra que o conjunto das coisas simples pode ser complicado, mas isso não diz respeito ao conceito de complexidade. ${ }^{22} \mathrm{O}$ segundo, é que não existe um paradigma da complexidade; esta é, antes de tudo, uma atitude, é uma "nova aliança" entre as ciências naturais e humanas (Prigogine \& Stengers, 1984), cuja utilidade transcende a postura positivista do conhecer, estabelecida pela construção cartesiana que domina as ciências e a sociedade.

Assim, a postura da complexidade do ponto de vista construtivista caminha no sentido da superação do paradigma clássico, inaugurado com o racionalismo, da dualidade cartesiana da causa-efeito, do conhecer o objeto em sua realidade, das soluçōes definitivas - na medida, também, em que o próprio problema é construído a partir da solução -, e traz à luz mais problemas que soluções (Stengers, 1990).

Para Santos (1987:9-10), "estamos no fim de um ciclo de hegemonia de uma certa ordem científica", que é o "modelo de racionalidade que preside a ciência moderna (...) a partir da revolução científica (...) desenvolvida basicamente no domínio das ciências naturais". Esse modelo, coerente com sua própria racionalidade, descredencia todas as demais formas de conhecimento que não utilizam seus próprios princípios e regras epistemológicas, isto é, estabelece duas distinções fundamentais, uma "entre conhecimento científico e conhecimento do senso comum, por um lado, e entre natureza e pessoa humana, por outro". Dessa forma, "a ciência moderna desconfia sistematicamente das evidências da nossa experiência imediata" (Santos, 1987:12).

21. BEzERRA (1994:181) atenta para o conceito de desconstruçāo, como proveniente do neoestruturalismo francês, e indica como referência quanto à noçăo e discussão crítica do conceito a obra de Frunk (1989).

2. "Utilizarei a noção de complexidade como questão que põe em jogo e explica os riscos que o conceito corre em relação ao observador: 'Será que é a mesma coisa, só que mais complicada, ou devemos pensar em termos de complexidade?' Vou tentar mostrar-Ihes que se coloca, então, a questăo da necessidade eventual de inventar novos tipos de problematizaçāo, que o operador não autorizava" (StENCERS, 1989:151). 
Assim é que, para Stengers (1989: 171-172), o primeiro uso da complexidade está no desafio de resgatar a singularidade da operação que o conceito oculta, sem que esse desmascaramento signifique "descobrir" a verdadeira realidade do objeto, mas sim reabrir a possibilidade de sua re-complexificação.

A pertinência dessa operação surge como iniciativa de resistência e superação de certo obscurantismo produzido pelo "especialismo" dos saberes e pela dominação da tecnociência para a apreensão do real:

não é, então, nem nova visão do mundo, nem novo tipo de teoria, mesmo se ela implica novas visões dos saberes e se refere a teorias. A questão da complexidade é prática: ela se coloca quando um novo encontro empírico (...) impõe um novo questionamento do poder atribuído a um conceito e atualiza uma dimensão da interrogação prática que tal conceito ocultava. (Stengers, 1989)

A desinstitucionalização na psiquiatria, na tradição basagliana, inscreve-se nesse 'período de transição', no qual inicia-se uma fase de afastamento do paradigma clássico, com sua desmontagem, e a conseqüente abertura de um novo contexto práticodiscursivo sobre a loucura e o sofrimento humano. Isso significa que, ao abrir um processo de re-complexificação da loucura, contribui com algumas estratégias cognitivas e práticas para o campo da teoria das ciências e do conhecimento.

Recorrendo mais uma vez a Santos (1987:7): "tal como noutros períodos de transição, difíceis de entender e de percorrer, é necessário voltar às coisas simples, à capacidade de formular perguntas simples".

Basaglia formula algumas dessas perguntas que, aparentemente, pareciam respondidas e absolutamente óbvias para a psiquiatria e para a sociedade, como, por exemplo, o que é a doença mental? e, o que é a psiquiatria?

Dando, pois, prosseguimento, o segundo uso da complexidade é pôr em cena e problematizar a posição daquele que coloca as questões nas ciências (Stengers, 1989: 162-171). Os mitos da neutralidade, do distanciamento crítico, da autonomia da tecnociência, são assim colocados em discussão no questionamento das relações entre ciência e poder, à medida que a impressão de que as ciências têm uma identidade é, em si mesma, um efeito de poder, assim como é um efeito de poder a aceitaçăo do fato de que as ciências sejam uma construção neutra e descomprometida da História (Stengers, 1989). 
Nesse mesmo sentido, para Bourdieu (apud Spink, 1992:20), trata-se da retórica da cientificidade, na qual tende-se a reproduzir a crença no valor de seus produtos e na autoridade de seus membros. A observação, afirma Maturana \& Varela (1990), depende do observador: e quem é esse observador psiquiatra que define e cataloga a loucura como alienação mental? Seria possível uma observação psiquiátrica que nada tivesse de relação com a cultura, com os princípios éticos e morais, com a normatividade?

Inscreve-se, nesse propósito, a iniciativa de Basaglia que, ao desenvolver sua crítica e ação política, põe no centro da discussão da questão psiquiátrica o papel e a função dos técnicos, seja do enfermeiro do manicômio, seja do pesquisador universitário, que devem ter como princípio a negação do ato terapêutico como ato de violência mistificada. A desinstitucionalização é um processo prático de desconstrução e, simultaneamente, um processo de invenção de novas realidades. E se hoje podemos assumir que a realidade é construída, podemos admitir ainda que pode ser desmontada para ser (permanentemente) reconstruída sobre novas bases.

A desconstrução, para Derrida (1990:76-77)

é um gesto a um só tempo estruturalista e antiestruturalista: desmonta-se uma edificação, um artefato, para fazer aparecer as estruturas, as nervuras ou o esqueleto (...). A desconstrução enquanto tal não se reduz nem a um método (redução ao simples) nem a uma análise; ela vai além da decisão crítica, da própria idéia crítica. É por isso que não é negativa, ainda que muitas vezes, apesar de tantas preocupações, a tenham interpretado assim. Para mim, ela acompanha sempre uma exigência afirmativa; diria até que ela não acontece jamais sem amor...

Procura-se demonstrar que a 'instituição negada' e a 'instituição inventada', tal como entendidas na tradição basagliana, são as faces desse mesmo processo construtivista, e não negativo ou negativista, como muitas vezes tem sido entendido, que implica envolvimento mais que puramente científico ou 'acadêmico', mas que é crítico, que é ação política, que é construção de uma nova realidade, sob a égide de outros pressupostos éticos e epistemológicos.

De Leonardis (1987:251) estabelece uma analogia entre esse processo de desconstrução-invenção com a idéia da formulação do conhecimento como "autocriação", baseada no princípio de "autopoiese", proposto por Maturana \& Varela (1980), que implica a realização de um processo prático-teórico, no interior da instituição, e novos valores críticos e práticos. 
Sob outro aspecto, que Stengers (1989) denomina de testemunha fidedigna, o processo de desinstitucionalização operado por Basaglia traz ao campo psiquiátrico a questão da modificação das experiências da loucura e do sofrimento humano, que são transformadas pelo efeito da institucionalização (e não apenas do asilamento, mas de toda a condição de ser apropriado pelo saber psiquiátrico). Esse efeito, a cronicidade, a demência, a irreversibilidade etc., testemunhas autênticas da verdade psiquiátrica, são explicadas pela psiquiatria como o 'curso natural' ou a 'evolução' da doença mental.

O processo de desinstitucionalização demonstra tornar-se possível construir e inventar novas perspectivas de vida e subjetividade para aqueles mesmos sujeitos, e não apenas 'evoluções' e 'prognósticos' da doença mental.

A complexidade, enfim, reporta ao problema ético das relações entre os homens e para com a natureza, porque coloca o problema do pensar e agir em termos de relações e não de objetos (Schramm \& Castiel, 1992). No contexto da desinstitucionalização, na medida em que esta coloca em discussão os conceitos de loucura, periculosidade, anormalidade, desvio e outros tantos, sobre os quais a psiquiatria construiu seu mandato terapêutico, legitimou e autorizou determinada ação institucional violenta e tutelar sobre os sujeitos assim classificados, e, na medida, ainda, em que renuncia a esse mesmo mandato, abre-se uma nova perspectiva de relação ética entre os homens e as instituições.

Porém, o problema da doença mental é paradigmático para a bioética médica...

não apenas porque revela a complexa interdependência entre a dimensão orgânica e a dimensão psíquica do ser humano, cuja 'separabilidade' é já de per se uma questão que pode ser considerada ética, tratando-se, no fundo, das relaçōes entre natureza e cultura, entre ambiente e sistema vivo, entre mente e corpo. A 'doença mental' é paradigmática, sobretudo, porque ilustra os desdobramentos paradoxais que pode assumir a medicalização da vida, ou seja, a reversibilidade simbólica que atinge a apropriação médico-psiquiátrica da doença mental. (Amarante \& Schramm, 1993:393)

Assim, este livro pretende levantar algumas reflexões, oriundas de diversos campos, tendências e correntes dos saberes científicos e da não-ciência, muitas das vezes distantes, muitas das vezes contraditórios, muitas das vezes incompatíveis, buscando não as suas divergências e hierarquias, mas o seu possível entrelaçamento, a sua necessária complexidade; não a subjugação de um saber sobre os demais, mas a subjunção desses saberes. Estou certo de que também não apresentarei nenhuma solução, mas 
apenas algumas 'outras histórias' para o estudo sobre a loucura e a psiquiatria, com o intuito de contribuir para o debate da reforma psiquiátrica. ${ }^{23}$ Pode-se, ao menos, esperar que o debate sobre a reforma psiquiátrica, ao incorporar alguns desses aspectos, possa seguir o mesmo caminho que Serres (1990b:179) aponta para a filosofia, qual seja, a de...

instruir-se sobre as ciências exatas antes de falar de organizações humanas, que representam um estágio de complexidade superior. Se este percurso for cortado ou negligenciado teremos, de um lado, pessoas que falarão do mundo com exatidão, mas que terão esquecido completamente a história e a cultura; e do outro, pessoas que farão ciências humanas, imperturbavelmente, em completa ignorância do mundo e de suas mudanças.

\section{Psiquiatria moderna: objeto e processo cognitivo}

A psiquiatria moderna nos tem ensinado que a doença mental existe desde sempre: uma descoberta aqui, outra acolá, vão-se somando e, com a acumulação das observações, chega-se a um estágio do conhecimento que possibilita fundar a medicina mental, primeira especialidade médica.

A ignorância com a qual os povos antigos tratavam os doentes, ora considerando-os possuídos pelos deuses ou demônios, ora atribuindo-lhes uma verdade transcendental da natureza humana, ora ainda excluindo-os da categoria do humano, é, para a psiquiatria, não mais que a constatação da sua pré-história, do seu estado teológico ou metafísico, na qual não existiam ainda os recursos necessários para o efetivo reconhecimento das doenças.

História da Loucura (Foucault, 1978) é um passo importante na desconstrução dessa mitologia científica, ao demonstrar que nem a doença mental nem a psiquiatria existiram desde sempre, mas que são objeto e saber datados historicamente. O trabaIho de Foucault é sucedido por outros de grande importância, como por exemplo os de

23 Faço menção ao capítulo Da complexidade - outras histórias para a ciência, em StEnGERS (1990:143-172). 
Rosen, ${ }^{24}$ Szasz, ${ }^{25}$ Basaglia, ${ }^{26}$ Castel,,${ }^{27}$ Birman, ${ }^{28}$ Machado, ${ }^{29}$ que aprofundam aspectos variados do processo de medicalização da loucura. ${ }^{30}$

Quanto a isso, falar em 'psiquiatria moderna' pode significar redundância, já que a psiquiatria é moderna por definição, isto é, nasce no cerne do projeto tecnocientífico da modernidade e que, antes desse nascimento, não seria rigorosamente correto falar em psiquiatria. Psiquiatria moderna, ou simplesmente psiquiatria, é esse conjunto de saberes e práticas sobre o objeto construído 'doença mental', cuja construção, a exemplo da reflexão filosófica, no seio da qual é parcialmente edificada, tem como pressuposto que o princípio da possibilidade do saber científico está na autonomia do observador (sujeito epistêmico) para com a observação (objeto epistêmico). ${ }^{31}$

No cerne do projeto da ciência, entende-se que o sujeito epistêmico, portador de uma subjetividade comandada pela razão, pode conhecer a realidade que se the apresenta. Se 'distanciado' do objeto, colocando-se num lugar neutro e imparcial, sem envolvimento subjetivo com o mesmo, o sujeito pode obter garantias de certeza e verdade. Em última instância, o método, adequadamente aplicado, possibilita e define a objetividade científica.

Por isso mesmo, levantar questões quanto à natureza das ciências na esfera da psiquiatria e das reformas psiquiátricas não é tarefa das mais fáceis. Para a psiquiatria, em consonância com a face de seu paradigma, as contribuições advindas de outras áreas são decorrentes da completa ausência de parâmetros científicos para julgar a positividade do saber psiquiátrico ou versar sobre a natureza da doença mental. Vale lembrar que não se está aqui referindo-se exclusivamente ao senso comum, mas também aos estudos humanísticos.

Ver ROSEN (1974).

Ver Szasz (1976, 1980a, b).

Ver BASAGlia et al. (1985).

Ver CASTEL (1978a).

Ver BIRMAN (1978).

Ver MACHADO et al. (1978).

* Cumpre adiantar que este livro não tem qualquer pretensão de percorrer nenhuma das trajetórias das obras anteriormente referidas, isto é, reescrever a história da loucura ou da psiquiatria, mas inspira-se e parte dos mesmos, para ensaiar e organizar algumas interrogaçōes e propor novas possibilidades.

31 Por esse motivo, quando referir-me aos períodos mais recentes da psiquiatria, estarei utilizando a adjetivação 'contemporânea' apenas com o objetivo de melhor precisar esta distinção, e psiquiatria moderna, apesar da redundância, quando julgar necessário chamar a atenção para seu pertencimento ao projeto da modernidade. 
No âmago da psiquiatria pergunta-se por que tais estudos não a reconhecem como ciência. Sonenreich, por exemplo, relata que, para escolher entre as várias propostas existentes no saber médico sobre as alterações mentais, procurou

orientação em epistemólogos, sociólogos, antropólogos, historiadores da medicina e na cultura em geral. E muitas vezes fiquei abalado, espantado. Li terríveis acusações contra a psiquiatria, a medicina, a ciência (...). Certas acusações eram irrespondíveis, esmagadoras... (Sonenreich, 1992:92)

E, mais adiante:

Os críticos da psiquiatria afirmam que ela pretende ser uma ciência absoluta, eterna, independente do tempo, da cultura. Dizem que a 'biologização' e a 'psicologização' se querem eternas, a-históricas, e não admitem terem surgido em certo momento da cronologia da humanidade... (...). (Ibid., p.95)

Ou ainda: "É difícil admitir que a doença mental seja uma invenção burguesa, quando ela está presente (aceita ou rejeitada) na cultura grega, na medieval, nas sociedades contemporâneas capitalistas ou sem classes" (Ibid., p.96).

Quais seriam essas terríveis acusações? As de Foucault, Rosen, Szasz, Basaglia, Castel, Birman, Machado...? Ou a de Feyerabend (1989:31) em defesa de uma epistemologia anarquista contra o racionalismo crítico, procurando desmontar a demarcação entre a ciência e o mito, quando afirma: "Certas pessoas consideram até a psiquiatria como uma ciência?"

Apesar de as resistências da psiquiatria, as ciências consideradas exatas passam também por esse processo de reflexão, o que tem sido fundamental para o seu próprio desenvolvimento. Nas palavras de Prigogine (1989:51-59), "a ciência expressa nossas interrogações frente a um mundo mais complexo e mais inesperado do que poderia imaginar a ciência clássica. Tivemos, pois, que abandonar a tranqüila quietude de já ter decifrado o mundo".

Mas, para a psiquiatria, isso não ocorre com facilidade; a tranqüila quietude não está abalada. Pelo contrário, assiste-se a freqüentes anúncios de sua absoluta positividade, por exemplo, de que as descobertas definitivas, das causas a terapêuticas da esquizofrenia e das doenças afetivas estão para acontecer a qualquer momento: é uma questăo de muito pouco tempo!

A psiquiatria tende a rechaçar as proposições dos saberes que lhe são externos, e não apenas aqueles que colocam em discussão os seus fundamentos. Comumente, classifica tais contribuições como totalmente desprovidas de conhecimento psiquiátrico 
e, portanto, desprovidas de verdade. Se se tratam de 'críticas' a ela dirigidas, oriundas do campo das ciências sociais e humanas, são entendidas como decorrentes da completa ausência de parâmetros científicos para julgar a positividade desse saber sobre a natureza da doença mental. Ou ainda, por extensão, se são não-saberes-psiquiátricos são simplesmente não-saberes, o que é outra característica da tradição moderna.

A ciência moderna olha para trás com os olhos da atualidade, interpretando sua história pregressa com base em conceitos sobre sua própria natureza e sobre a natureza de seu objeto de uma forma retroativa. Partindo-se do pressuposto de que o conceito, tal como se apresenta contemporaneamente, é suficientemente adequado para explicar e compreender o fenômeno antes mesmo da sua formulação, aplica-o ao passado porque o considera a-temporal. Assim sendo, a psiquiatria julga-se capaz de identificar casos de psicoses afetivas, histerias e esquizofrenias, nos relatos de loucuras da Grécia Antiga, e assim por diante. Dessa forma, tais doenças foram exatamente a mesma coisa que são atualmente; apenas o estado da arte psiquiátrica não era ainda possível para detectá-las e defini-las corretamente. A partir da fundação de uma medicina mental, a loucura torna-se, senão exclusiva, mas, certo que, dominantemente, verdade médica (Birman, 1978:2).

A negação dessa 'eternidade' da doença mental não implica ainda, absolutamente, a negação da "vivência" ${ }^{32}$ do sofrimento ou da loucura, e, mais ainda, não implica necessariamente a rejeição quanto à possibilidade de existirem expressões orgânicas e/ou psicológicas, e/ou culturais; muito pelo contrário.

Disse que não implicava a rejeição quanto à possibilidade de existirem tais expressões, porque parece absurdo 'afirmar' que as mesmas não possam existir - e estaría-se sendo muito pouco conștrutivista. Entretanto, tal existência não significa, em contrapartida, como pretende a psiquiatria, certas psicanálises e certas sociologias, que o fenômeno seja, em sua totalidade e em sua exclusividade, ou físico, ou psicológico ou social.

Eis porque um dos objetivos deste livro é contribuir para a continuidade da transposição dessa ordem de questões para o debate no campo da psiquiatria e da reforma psiquiátrica. É contribuir para que essas estejam no cerne das reflexões que colocam

3 O termo vivência é utilizado no sentido proposto por Ortega y Gasset, em um ensaio sobre Husserl, com o fim de traduzir o vocábulo Erlebnis, sem correspondente em idiomas neolatinos: "o certo é que a palavra 'vivência', no sentido de Erlebnis, significa experiência vivida subjetivamente, isto é, experiência interna, e não 'experiência de vida' em acepção vulgar, como vem sendo mais freqüentemente empregada em nosso meio" (apud Nobre de Meto (1970:169). 
em questão as tecnociências em sua busca da verdade, em sua busca da forma do conhecimento verdadeiro. É, enfim, contribuir para um reabrir de possibilidades de saberes que busquem pluridimensionalidades (Serres, 1990a) ou multidimensionalidades (Morin, 1985), ou ainda, para a construção da complexidade de um novo espírito científico (Bachelard, 1995), ou de uma nova aliança (Prigogine \& Stengers, 1984). 


\section{Capítulo 2}

\section{paradigma psiquiátrico}

\section{Simplificar para conhecer (ou de como a humanidade ganhou uma casa de orates)}

A psiquiatria nasce de uma reforma, isto é, nasce como produto das reformas operadas em instituições sociais na França revolucionária. E, nesse exato momento, passa a ser, ela mesma, motivo de críticas e objeto de outras reformas. De um lado, questiona-se sua ousadia teórica e prática; de outro, seu excessivo poder. Desde então, muitos são aqueles que se colocam contra a ameaçadora presença dos loucos nas ruas.

A medicina geral, por sua vez, não vê com simpatia a pretensão desta co-irmã a medicina mental -, em tomar parte do mesmo campo científico, tamanha a sua carência de bases concretas e positivas que justifiquem tal incorporação.

Artistas, filósofos, poetas, anarquistas denunciam o autoritarismo e o controle exercido por essa intervenção, que tolhe as liberdades e autonomias e cerceia a verdade e a essência do delírio. Garsonet, pouco depois, denuncia: "essa autoridade médico-legal exorbitante, esse despotismo ilimitado que ultrapassa o do plantador colonial sobre os negros". ${ }^{33}$

Os alienistas combatem entre si pela posse da verdade sobre a alienação, oscilando entre as explicações psicológicas ou somáticas. ${ }^{34}$ Nesse período acontece algo de extremamente novo, que se pode expressar numa só frase: a loucura é apropriada conceitualmente pelo discurso médico, tornando-se, a partir de agora, única e exclusivamente, doença mental.

Garsonet apud Castel (1978a:253).

Expressōes estas que já eram correntemente utilizadas na época: “... duas escolas rivais dividem e dividirão muito tempo ainda os médicos alienistas: a escola somatista e a escola psicológica" (FALRET apud BIRMAN, 1978:46). 


\section{Loucura: verdade médica}

Desde Platão a loucura tem sido objeto de reflexão da filosofia como campo de saber sobre a natureza humana, a alma, as paixōes, a ética e a moral. A filosofia trata, ainda, do próprio processo do conhecimento, processo este que passa a merecer maior atenção na Idade Clássica, com base nas novas descobertas da ciência. E, antes da ciência moderna, compete à filosofia 'falar' do real, da verdade, e da verdade do real. Os homens de saber são, acima de tudo, filósofos.

Como passamos a conhecer após História da Loucura (Foucault, 1978), no século XVII são criados grandes espaços de internamento, denominados Hospitais Gerais onde, por meio das cartas régias ou das prisões arbitrárias, é reclusa toda a sorte de marginalizados, pervertidos, miseráveis, delinqüentes e, dentre eles, os loucos.

O Hospital Geral, ou A Grande Internação, como denomina Foucault (ibid., p.45-78) utilizando-se de uma formulação da época, é, ao mesmo tempo, espaço de assistência pública, acolhimento, correção e reclusão.

Soberania quase absoluta, jurisdição sem apelações, direito de execução contra o qual nada pode prevalecer - o Hospital Geral é um estranho poder que o rei estabelece entre a polícia e a justiça, nos limites da lei: é a terceira ordem da repressão. Os alienados que Pinel encontrou em Bicêtre e na Salpêtrière pertenciam a esse universo. (ibid., p.50)

Os alienados, percebidos pelo senso comum como a parcela violenta e perigosa desse contingente, são geralmente mantidos acorrentados para que não se corra riscos com sua denodada periculosidade. Também no âmbito da filosofia, como demonstra Foucault citando Descartes, se percebe o louco como despossuído de razão, com “um cérebro tão perturbado e ofuscado pelos negros vapores da bílis" (apud Foucault, 1978: 45), que permite compará-la ao sonho e ao erro.

É também Foucault, em O Nascimento da Clínica, que demonstra como o Hospital Geral torna-se, posteriormente, uma importante instituição médica, ou seja, é de tal forma capturado pela medicina que torna-se a instituição médica por excelência, lugar privilegiado de produção e exercício do saber médico. Visto por outro ângulo, a medicina passa a ser uma prática e um saber cujo exercício torna-se eminentemente hospitalar. Para Machado (1982:63-64), "não se trata, malgrado o nome, de uma instituição médica, mas de uma estrutura 'semijurídica', entidade assistencial e administrativa que se situa entre a polícia e a justiça". 
A possibilidade de aglutinar os loucos em um mesmo espaço, para conhecer e tratar suas loucuras, permite o nascimento da psiquiatria. Assim é que, para Machado (ibid., p.63), com base em "uma relação com o louco que se dá ao nível das instituições (...), o hospício é considerado o a priori da percepção médica" ${ }^{35}$

O médico, filósofo, matemático e enciclopedista Philippe Pinel tem importante papel nessa transformação. Papel este que, ao contrário do que muitos já sabem, não é restrito ao campo da psiquiatria. Como um dos fundadores da clínica médica, ele assume, em 1793, a direção do Bicêtre, onde opera os primeiros momentos dessa modificação. Manda desacorrentar os alienados e inscreve suas alienações na nosografia médica. Esquadrinha o Hospital Geral e nele reserva um primeiro espaço rigorosamente médico para os alienados. ${ }^{36}$

Pinel participa do grupo conhecido como Os Ideólogos, de enorme importância para o pensamento francês no fim do século XVIII, em pleno período revolucionário. Esse grupo busca uma base verdadeiramente científica para o conhecimento dos fenômenos da realidade, tomando como referência principal o modelo da História Natural. Para Os Ideólogos, "o conhecimento era um processo cuja base era a observação empírica dos fenômenos que constituíam a realidade” (Bercherie, 1989:31).

Nessa tradição, a filosofia objetiva o conhecimento do homem diante do que Ihe é impresso pelas suas experiências, para com si próprio e para com o que lhe é exterior. Esse método analítico-filosófico situa-se na tradição de Locke e Condillac que, adotado pelos Ideólogos, é especialmente aplicado à medicina por Cabanis.

A 'teoria do conhecimento' de Locke é, de certa forma, uma resposta contrária à doutrina das idéias de Descartes. Para Locke, as idéias constituem-se a partir da experiência empírica, pois todo o conhecimento humano tem origem na 'sensação', com base na qual são formadas as idéias - das mais simples às mais abstratas e complexas. A 'sensação', embora não seja suficiente para capturar a essência absoluta da realidade, permite um substancial paralelismo que, embora aproximativo, é válido para o conhecimento do real, senão o único meio realmente capaz para tal objetivo.

35 “Percepção aqui é a maneira de considerar o louco intimamente ligada ao modo de agir sobre ele e que depende de outras regras, de outros critérios que não o discurso teórico, embora de modo algum seja ausência de discurso ou exclua saber" (MACHADO, 1981:62-63).

36 "A vereança de Itaguaí, entre outros pecados de que é argüida pelos cronistas, tinha o de não fazer caso dos dementes" (De como Itaguaí ganhou uma casa de orates), em O Alienista, p.17-18. 
A clínica nasce inspirada nessa tradição filosófica-nominalista, em que é fundamental a relação "do ato perceptivo com o elemento da linguagem". Para Condillac, citado por Pinel na Nosographie,

analisar nada mais é do que observar em uma ordem sucessiva as qualidades de um objeto, a fim de lhes dar no espírito a ordem simultânea em que elas existem... Ora, qual é esta ordem? A natureza a indica por si mesma; é aquela na qual ela apresenta os objetos. (Foucault, 1977:108)

É nesse contexto epistemológico que Pinel elabora o Traité MédicalPhilosophique sur L'aliénation Mentale, que aborda a primeira incursão especificamente médica sobre a loucura, e que segue a mesma metodologia histórico-natural de sua Nosographie Philosophique ou La Méthode de L'analyse Appliquée à la Médecine. Para a História Natural, conhecer é classificar, separar e agrupar os diferentes fenômenos em ordens aproximativas. Dessa forma, se a loucura é considerada um rompimento com a racionalidade, rompimento este que se expressa por meio de determinados sinais, precisos e constantes, pode ser então classificada e agrupada, de acordo com suas aproximações e distanciamentos, em classes, gêneros e espécies, enfim, numa nosografia.

Ainda em conseqüência dessa postura, a nosografia é 'filosófica' porque se trata de um método de 'análise', que está em oposição à metafísica enquanto "filosofia primeira", tal como proposta por Descartes. Para Pinel, essa metafísica 'cartesiana' é um exercício especulativo que pretende ir além dos ensinamentos da experiência em si.

Para Castel, essa orientação filosófica, contrariamente à metafísica,

recusa as especulações arrojadas sobre as causas obscuras dos fenômenos. (...) O homem é maleável pela experiência, visto que todos os seus conhecimentos the vêm do exterior; todas as idéias e os conhecimentos são um composto de sensações e podem ser reduzidos pela análise de seus elementos mais simples. É o obscurantismo metafísico que visa um 'além' dos fenômenos. A ciência contenta-se em encontrar seu ordenamento racional limitando-se ao que é dado na experiência. Ela distingue o essencial do acessório, o constante do acidental, porém, a partir do que aparece à observação atenta. (Castel, 1978 a:103)

Ao cientista compete apreender o fenômeno na sua essência, procurando evitar inserir nesse processo suas próprias interpretações pessoais, sua subjetividade, tarefa assumidamente impossível mas que, certamente, o aproxima do conhecimento do 
real. Ainda para Castel (idem): “a conseqüência prática dessa orientação na medicina mental é de dirigir a atenção para os sinais ou sintomas da loucura em detrimento da procura de sua sede no organismo".

Conhecer a loucura é observar, descrever e classificar o que se chama às vistas do alienista como sendo estranho ao padrão moral. Para Bercherie (1989:31), Pinel funda uma tradição - a da Clínica - como orientação consciente e sistemática. Os hábitos bizarros, as atitudes estranhas, os gestos e olhares são registrados e comparados com o que está perto, com o que é semelhante ou diferente. Colocado em um lugar da ciência que, acredita-se, não é contaminado pelas influências da cultura, da economia e da sociedade, o alienista, valendo-se de sua percepção social, determina o que é normal e o que é patológico. Esse é o método do conhecimento, o que opera a passagem da loucura para a alienação mental. ${ }^{37}$

No que tange ao pensamento político, Locke defende uma natureza absolutamente livre e independente dos homens, os quais não devem ser submetidos nem ao absolutismo divino nem ao dos regimes políticos. Pinel inscreve-se nessa mesma ordem, ao propor a liberdade dos loucos que, embora liberados das correntes, devem ser submetidos a um tratamento asilar, sob um regime de completo 'isolamento'. Este, no entanto, não significa a perda da liberdade, pois, muito pelo contrário, é o tratamento que pode restituir ao homem a liberdade subtraída pela alienação.

É esse conjunto de idéias que Pinel apreende, elabora e desenvolve no Traité, no qual a loucura, tornada alienação mental, nasce nesse duplo campo de saberes, ou no campo articulado 'entre' os saberes médico e filosófico. Mas, como é sabido, antes de Pinel já se falava, se tratava e se internava a alienação mental. Chiarugi, na Itália, e Tuke, na Inglaterra, por exemplo, haviam humanizado os hospícios e, da mesma forma, liberado os loucos; Haslan e Daquin já o haviam precedido no que diz respeito ao tratamento moral; a literatura aponta ainda muitos outros exemplos.

37. "Uma vez desonerado da administração, o alienista procedeu a uma vasta classificação dos seus enfermos. Dividiu-os primeiramente em duas classes principais: os furiosos e os mansos; daí passou às subclasses, monomanias, delírios, alucinações diversas. Isto feito, começou um estudo aturado e contínuo; analisava os hábitos de cada louco, as horas de acesso, as aversões, as simpatias, as palavras, os gestos, as tendências; inquiria a vida dos enfermos, profissão, costumes, circunstâncias da revelação mórbida, acidentes da infância e da mocidade, doenças de outra espécie, antecedentes na família, enfim, como não o faria o mais atilado corregedor. E cada dia notava uma observação nova, uma descoberta interessante, um fenômeno extraordinário. Ao mesmo tempo estudava o melhor regímen, as substâncias medicamentosas, os meios curativos e os meios paliativos, não só os que vinham dos seus amados árabes, como os que ele mesmo descobria, à força de sagacidade e paciência". O Alienista, p.23. 
Então, onde se situa a especificidade da contribuição de Pinel? Tratando-se de uma área de conhecimento que aspira tomar parte da medicina, abordando medicamente um certo tipo de doenças para as quais a medicina apenas tangencialmente se voltava, construindo uma síntese própria para classificar e tratar a alienação e organizar os meios de assistência, constitui-se, assim, numa 'medicina especial', que se configura como a primeira especialidade médica. A loucura, até então objeto da filosofia que, em resumo, tratava das questões da alma, das paixões e da moral, passa, com Pinel, a ser objeto também da medicina. Em outras palavras, um determinado aspecto da ética e da moral deixa de ser objeto exclusivo da filosofia (ou do senso comum, por sua evidente desqualificação), para pertencer também ao campo da medicina. Essa é a operação básica instruída por Pinel, a qual possibilita a inscrição da loucura, dos desvios da paixão e da moral no conceito de doença.

Pinel é, a um só tempo, um construtor teórico e prático. Reúne e dá corpo aos saberes médicos e filosóficos que vinham sendo produzidos sobre a loucura, ao mesmo tempo em que opera transformações práticas no lidar social e institucional com a mesma. Com ele, a loucura passa a receber definitivamente o estatuto teórico de alienação mental, o que imprimirá profundas alterações no modo como a sociedade passará a pensar e a lidar com a loucura daí por diante. Se, por um lado, a iniciativa de Pinel define um estatuto patológico para a loucura, o que permite com que esta seja apropriada pelo discurso e pelas instituições médicas, por outro, abre um campo de possibilidades terapêuticas, pois, até então, a loucura era considerada uma natureza externa ao humano, estranha à razão. Pinel levanta a possibilidade de cura da loucura, por meio do tratamento moral, ao entender que a alienação é produto de um distúrbio da paixão, no interior da própria razão, e não a sua alteridade.

Alienação significa o ato de estar fora de si próprio, de tornar-se um outro, de perder a consciência de si e das coisas. A palavra, tornada conceito, pretende dizer algo do fenômeno que procura conceituar. Seria apenas uma ironia da história?, pois, 'alienante' torna-se a expressão que melhor definirá a prática e o saber psiquiátrico? Qual outro campo de saber tem autorizado uma prática tão segregante, tão excludente e violenta? ${ }^{38}$

A 'percepção' (Foucault, 1978) não apenas médica, mas social, constata que, de fato, proliferam os casos de alienação mental no seio da sociedade, fenômeno que não

"Quem nos afirma que o alienado não é o alienista?", refletiu um vereador de Itaguaí em $O$ Alienista, p.40. 
encontra ainda suficiente explicação no sistema teórico dominante na medicina. ${ }^{39}$ É por intermédio do concurso da filosofia que tal aumento pode ser explicado como conseqüência do progresso desmesurado, ora pelo abandono das antigas crenças, ora pelas comoções políticas, ora pela perda dos padrões éticos, que imprimem degradações morais nos indivíduos.

Para Pinel, respondendo às críticas a insinuações dos anatomopatologistas quanto à ausência de base orgânica para a alienação mental,

seria um erro tomar a alienação mental para objeto de investigações, entregando-se à discussões vagas sobre a sede do entendimento e a natureza das suas diversas lesões (..) porque nada há de mais obscuro e impenetrável. (apud Teixeira Brandão, 1886:62-63)

Contudo, mesmo alguns seguidores de Pinel admitem que algumas moléstias mentais têm uma base orgânica, muito embora a maioria seria, esta sim, autenticamente alienação mental. Se a causa destas últimas não é anatomopatológica, a explicação deve ser buscada na cultura a no desenvolvimento do processo civilizatório. Em 1838, Esquirol enuncia que "a loucura é o produto da sociedade e das influências morais e intelectuais" (Castel, 1978a:111-112).

Somente uma referência que não seja exclusivamente médica, que estenda seu marco teórico à filosofia, ao saber complexo e transcendental, saber sobre a alma, as paixões, a moral e a cultura, poderia dar conta desse novo tipo de moléstias que se apresentam. Em parte explicada pela filosofia, a alienação mental pode ser entendida para além de seu substrato orgânico; em parte pela medicina, pode garantir a assistência e o tratamento que delas necessitam os por ela acometidos.

39 Essas análises dos alienistas contêm observaçōes muito importantes que deveriam merecer, em algum momento, estudo mais aprofundado, uma vez que fazem referência ao visível aumento de casos de alienação mental, cuja origem é relacionada a aspectos da estrutura social e do 'desenvolvimento civilizatório'. Apresento algumas hipóteses que não se excluem e năo pretendem ser definitivas. Por certo, poderia-se tratar do processo de medicalização do social, definido por Foucault (1979), quando a medicina passa a apropriar-se conceitualmente dos fenômenos sociais; poderia, também, significar um processo de extensão do conceito de loucura, desrazão ou desvio, passando a abarcar outras tantas situaçōes fronteiriças de 'desajustamento' social; poderia, ainda, estar acontecendo um aumento real dessas situações na medida em que as rápidas e tumultuadas mudanças sociais, culturais e econômicas fariam aumentar as exigências para com os indivíduos, e, portanto, aumentariam certas dificuldades no adaptar-se socialmente, o que reforçaria as teorias sobre o desvio e o estigma como categorias de acusação; poderia, finalmente, suceder que, com essas mesmas mudanças no quadro ético, ideológico e científico, a loucura, a desrazão, o desvio e o desregramento estivessem em franco processo de dessacralização, de desmistificação e de desritualizaçāo que, assim, não encontrassem mais as mesmas soluções ou enquadres oferecidos pela religiăo, pelos mitos, pelos ritos e pelas culturas, tornando-se, então, suscetiveis de explicação predominantemente médica. 
A medicina, contudo, calcada na anatomopatologia, é a ciência do fim do século: não existe legitimidade maior do que a de uma ciência que abre os corpos a aponta as lesões. Essa posição, crescente mesmo entre seus seguidores, não é suficiente para dobrar a postura de Pinel, que insiste em afirmar que a alienação mental não tem causas físicas. Tal irredutibilidade só vem prejudicar o projeto de inscrever essa nova ciência no terreno da medicina. Contudo, tomadas em conjunto, suas proposições são consideradas corretas mesmo pelos seus opositores: as alienações regridem com o tratamento moral, o que, na prática, confirma suas hipóteses. É o tratamento moral que apresenta resultados de fato, e não a farmacopéia e a parafernália de tratamentos físicos propostos pelos seus opositores.

Com o mandato social e o prestígio que Pinel adquire pelo conjunto de sua obra médico-filosófica e pelos resultados terapêuticos objetivos, a medicina mental vai-se constituindo e consolidando o seu lugar na ciência médica. ${ }^{40}$ É o mesmo mandato social que possibilita a transformação de Bicêtre em um hospital especial, o primeiro da história da medicina, e onde começam a formar-se os primeiros médicos especiais: os alienistas.

A loucura é entendida como 'alienação', como o estado de contradição da razão, portanto, como o estado de privação de liberdade, de perda do livre-arbítrio. Se alguém é alienado, isto é, se não se the pertence, não há razão, não há liberdade. ${ }^{41}$

Liberdade, pois, é palavra-chave, uma vez que está inscrita nos ideais da Revolução Francesa, nas obras de Pinel, ou no projeto político de Locke. Assim é que Leuret, referindo-se aos pioneiros da psiquiatria francesa, antes e depois de Pinel, considera que "há impulsos instintivos que privam algumas vezes o homem de sua liberdade, ou ainda que, como resultado de uma doença mental, o homem perde o livre-arbítrio" (Birman, 1978:9).

Hegel inspira-se nos eventos da Revolução Francesa para construir as linhas básicas de seu pensamento e, dentre outros, lê Pinel, cita-o, comenta-o e explicitamente apropria-se de algumas de suas idéias, inclusive daquelas relativas à alienação mental. ${ }^{4} 2$

* A expressão medicina mental era utilizada já naquela época. Ver, por exemplo, FalRet apud Birman (1978:64-65): “...não é a título de meio puramente moral ou puramente físico que um agente terapêutico deve ser aceito na medicina mental; é a título de agente eficaz e ativo, simultaneamente físico e moral...".

41 "Supondo o espírito humano uma vasta concha, o meu fim, Sr. Soares, é ver se posso extrair a pérola, que é a razão; por outros termos, demarquemos definitivamente os limites da razão e da loucura. A razão é o perfeito equilíbrio de todas as faculdades; fora daí insânia, insânia e só insânia." O Alienista, p.29.

4 A esse respeito, ver o capítulo Loucura e razão - Hegel e Pinel, ou a r.ızão gloriosa, em Pelbart, (1989:45-55). 
Hegel introduz no pensamento filosófico a categoria de alienação que, tomada com base em seu significado latino (alienare: ação de se tornar outrem), e após a leitura de Pinel, constitui-se no "fato de um ser, a cada etapa de seu devir, aparecer como outro distinto do que era antes".

Em outras palavras: "ação de se tornar outrem, seja se considerando como coisa, seja se tornando estrangeiro a si mesmo" (Japiassu \& Marcondes, 1991:16).

Ao tratar da Divisão da filosofia do direito, Hegel afirma:

Posso alienar minha propriedade... o que, de um lado, é meu, e, de outro, contém em si mesmo o momento da exterioridade. Em conseqüência, inalienável é minha razão, minha liberdade, minha personalidade e, absolutamente falando, o que contém em si, de modo essencial, toda a minha liberdade. ${ }^{43}$

E, ainda, referindo-se especificamente à alienação mental, Hegel considera-a "não a perda abstrata da razão (...) (mas) somente contradição na razão que ainda existe". ${ }^{44}$

Definição inspirada em Pinel que, contrariamente à opinião dominante, entrevê a possibilidade de tratamento para a alienação mental. E, se é possível tratar, se é possível reeducar (moralmente), é porque não há perda absoluta da razão ou da liberdade.

É tendo por base a discussão da alienação mental, tal como proposta por Pinel, que Hegel relativiza o conceito da sua radicalidade máxima - a alienação mental - para a alienação enquanto condição inerente ao homem na qual todo o sujeito é alienado da sua real condição social, da sua condição de sujeito.

A alienação, contrariamente ao pensamento até então dominante, não significa perda total da razão ou da liberdade. Estas, o homem jamais perde-as em sua totalidade e prova disso está em que, mesmo na condição de alienado, o que existe é contradição interna à razão.

Assim, não havendo perda absoluta da razão ou da liberdade, torna-se possível resgatar a totalidade do ser humano em reconstituir a moral. Para Hegel (apud Foucault, 1978:476),

o verdadeiro tratamento psíquico apega-se à concepção de que a loucura não é a perda abstrata da razão, nem do lado da inteligência, em do lado da vontade e de sua responsabilidade, mas um simples desarranjo do espí-

43 Hegel apud CoRbisier (1981:104).

4. De acordo com Foucautr (1978:476), a abordagem de Hegel sobre a alienação mental está inserida na nota do $§ 408$ de sua Enciclopédia das Ciências Filosóficas. 
rito, uma contradição na razão que ainda existe, assim como a doença física não é uma perda abstrata, isto é, completa, da saúde (de fato, isso seria a morte), mas uma contradição dentro desta. Esse tratamento humano, isto é, tão benevolente quanto razoável da loucura... pressupõe que o doente é razoável a encontra aí um sólido ponto para abordá-lo desse lado. ${ }^{45}$

A positivação da alienação percorre o caminho às avessas, sendo re-apropriado pela filosofia. ${ }^{46}$

\section{O moral da história}

Mas, se a filosofia, tal como a adota Pinel, objetiva o conhecimento do homem diante do que lhe é impresso pelas suas experiências, para com si próprio e com o que lhe é exterior, o que é exterior ao homem, senão o meio, o que é essencialmente moral? Desse modo, dentre as causas da loucura estão aquelas, certamente mais importantes na teoria de Pinel, de ordem moral. De acordo com Bercherie, tais causas são: as paixões intensas e muito contrariadas e prolongadas; os excessos de todos os tipos, as irregularidades dos costumes e dos hábitos de vida, e a "instituição" (no sentido de instituter [professor], ou seja, a educação) perniciosa, fosse por brandura ou dureza excessivas, que seria predisponente (Bercherie, 1989:39). ${ }^{47}$

Para Hegel, a loucura é a subversão da hierarquia interna na qual a consciência ordena o universo sensitivo, ideativo e volitivo. Enquanto no indivíduo 'são' a consciência coordena todas as atividades, todos os elementos constitutivos da razão, no alienado um desses elementos foge ao controle e à hierarquia e instala a contradição.

Mas que elementos são esses capazes de subverter a ordem e a hierarquia? Para Hegel, são as "determinações egoísticas do coração", a vaidade, o orgulho, outras paixōes e imaginações, esperanças, amor e ódio (Pelbart, 1989:47-48). Enfim, a loucura é tão maior quanto maior for a parcela de razão, pois a contradição é maior.

5 Idem.

* Como se sabe, Marx retoma o conceito de alienação de modo diverso, ou seja, no sentido de que a alienaçāo é originalmente econômica no momento em que o "operário vende a sua força de trabalho como mercadoria, tornando-se escravo", ou ainda "quando dizemos hoje que o trabalho é um instrumento de alienação na economia capitalista, estamos reconhecendo que o operário é despossuído do fruto de seu trabalho" (JAPIASSU \& MARCONDES, 1991:16).

4 Em nota complementar, Bercherie adenda ainda: "O que se visava aqui, essencialmente, eram as paixōes 'artificiais' (orgulho, ambição, gosto pelo luxo) do mundo 'moderno', bem como a decadência dos costumes nas cidades. A Ideologia retomou, em parte, temas pré-românticos de Rosseau, e aspirava a uma reforma dos costumes" (BERCHERIE, 1989:46). 
De acordo com Mello Moraes (1855:193), as paixões, para Pinel, são “modificações desconhecidas da sensibilidade física e moral, das quais somente podemos diferenciar e assinalar os caracteres distintivos por sinais exteriores"

Dessa maneira, existem: "as paixōes debilitantes ou opressivas, assim como o desgosto, o ódio, o temor, as saudades, os remorsos, o ciúme, a inveja, que são o gérmen de tantas desordens e males na vida social" (ibid., p.194).

No entanto, existem as paixões alegres (a própria alegria, o orgulho, o amor, o enlevo estático, ou admiração aplicada aos objetos de culto) (idem). As duas ordens de paixões podem ser perfeitamente normais, se em grau e intensidade adequados. Porém, se em proporções excessivas, exageradas, desmedidas, podem ocasionar a

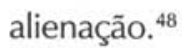

Dessa forma, sendo a alienação mental predominantemente um distúrbio das paixões, torna-se possível tratá-la reeducando a mente alienada. ${ }^{49} \mathrm{E}$, ao formular tal assertiva, Pinel contraria a concepção dominante de que todo os tipos de alienação são incuráveis; mais ainda, retoma a idéia de Hipócrates da possibilidade do método expectante, na qual "a doença, tal como nos aparece, é essencialmente uma reação salutar do organismo contra a ação de causas que perturbam seu equilíbrio, e de que sua conclusão natural é a cura" (Bercherie, 1989:35-40).

Seguindo essa mesma tradição hipocrática, o médico não deveria entregar-se a tentativas especulativas de encontro de tratamentos definitivos, específicos, no abrir corpos e no prescrever poções, mas limitar-se aos recursos terapêuticos de caráter auxiliar, paliativo, como forma de contribuir com o organismo em sua tarefa autoreorganizadora (ibid., p.41). Tendo como base tais princípios, condena com veemência os "empíricos e sua busca de um remédio 'específico'", o "ativismo terapêutico e o intervencionismo forçado e intempestivo", que ocasionam os estados deploráveis em que os alienados são enviados para o Bicêtre, "exangues e moribundos", de tal forma que, "quando eles escapavam, era freqüente ficarem dementes e incuráveis", em decorrência de tais posturas (ibid., p.40).

4 A esse respeito ver, por exemplo, o Anexo 1, de Mello Moraes (1855:159-162).

* "Mas a ciência tem o inefável dom de curar todas as mágoas (...) - A saúde da alma, bradou e e: é a ocupação mais digna do médico". O Alienista, p.18. 


\section{O remédio universal ${ }^{50}$}

O primeiro e mais fundamental princípio terapêutico do 'tratamento moral', o princípio do 'isolamento do mundo exterior', é uma construção pineliana que até os dias atuais não está totalmente superada. Se as causas da alienação mental estão presentes no meio social, é o isolamento que permite afastá-las, transportando o indivíduo enfermo para um meio no qual as mesmas não podem mais prejudicá-lo.

É o próprio Pinel quem explica e justifica tal processo:

Em geral é tão agradável, para um doente, estar no seio da família e aí receber os cuidados e as consolaçōes de uma amizade tenra e indulgente, que enuncio penosamente uma verdade triste, mas constatada pela experiência repetida, qual seja, a absoluta necessidade de confiar os alienados a mãos estrangeiras e de isolá-los de seus parentes. As idéias confusas e tumultuosas que os agitam são provocadas por tudo que os rodeia; sua irritabilidade continuamente provocada por objetos imaginários; gritos, ameaças, cenas de desordem ou atos extravagantes; o emprego judicioso de uma repressão enérgica, uma vigilância rigorosa sobre o pessoal de serviço cuja grosseria e imperícia também se deve temer, exigem um conjunto de medidas adaptadas ao caráter particular dessa doença, que só podem ser reunidas num estabelecimento que Ihes sejam consagrados. (apud Castel, 1978a:86-87)

Esquirol, posteriormente, apresenta cinco principais razões para justificar o isolamento:

1. garantir a segurança pessoal dos loucos e de suas famílias;

2. liberá-los das influências externas;

3. vencer suas resistências pessoais;

4. submetê-los a um regime médico;

5. impor-Ihes novos hábitos intelectuais e morais. (apud Foucault, 1979:126)

so Disse o alienista: “'O principal nesta minha obra da Casa Verde é estudar profundamente a loucura, os seus diversos graus, classificar-lhes os casos, descobrir enfim a causa do fenômeno e o remédio universal. Este é o mistério do meu coraçấo. Creio que com isto presto um bom serviço à humanidade'. 'Um excelente serviço, corrigiu o boticário'". O Alienista, p.21. 
O isolamento cientificamente fundamentado afasta o louco da fa uí a, ba c . da de, da sociedade: "a seqüestração é a primeira condição de qualçue te apètutica da loucura" e, "a partir desse princípio, o paradigma da internação ira ci m । al, por um século e meio, toda a medicina mental" (Castel, 1978a:86).

Pinel recupera a idéia de Tenon, de que:

é impossivel distribuir os loucos, cuja loucura se pretende tratar, como se distribui doentes comuns ou mulheres grávidas. Um hospital é, de certa forma, um instrumento que facilita a cura; porém existe uma grande diferença entre um hospital de febris feridos e um hospital de loucos curáveis; o primeiro oferece somente um meio de tratar com maiores ou menores vantagens, em função de ser mais ou menos bem distribuído, ao passo que o segundo tem, ele próprio, função de remédio. ${ }^{51}$

O asilo é o lugar do tratamento moral; é, também, por si próprio, o tratamento moral. Além do isolamento, o asilo permite que se opere o 'afastamento', isto é, a separação dos diferentes tipos de enfermidades em locais distintos, de forma a favorecer as aproximações, as características comuns a elas.

Afastadas, as enfermidades podem ser melhor conhecidas, distribuídas metodicamente, quer dizer, cientificamente, pois as aparências entre determinados tipos de enfermidades agrupadas em um espaço comum vêm comprovar o saber que as define como de um mesmo tipo. É a aplicação prática, no estudo das enfermidades, da História Natural, e em particular a obra de Buffon, que serve de "modelo e ideal para essa orientação" (Bercherie, 1989:32).

Os diferentes tipos de alucinações e delírios são, por essa racionalidade, comparados entre si por suas exterioridades, assim como o botânico naturalista compara tipos e formas de folhas, caules e frutos, e esse é um conhecimento empírico, que, em si, traz uma verdade embutida.

Nas palavras de Pinel,

uma distribuição metódica dos alienados no hospício, em diversos departamentos, possibilita a rápida apreensão das respectivas medidas que devem ser tomadas quanto à sua alimentação, limpeza, regime moral e físico. As necessidades entre eles são então calculadas e previstas, as diversas lesões do entendimento são apreendidas através de seus caracteres distintivos, os fatos observados são comparados e reunidos com outros fatos análogos, ou melhor, convertidos em sólidos resultados da experiência. (apud Castel, 1978a:84) 
O tratamento moral, ou a "polícia interior", no entendimento de Pinel, dá-se inicialmente com o próprio regime disciplinar do asilo, mas, também, com a instituição do trabalho, no caso, o trabalho terapêutico, este poderoso remédio contra o delírio, que resgata idéias falsas, e chama a consciência à realidade.

O isolamento é uma mediação necessária, pois a sociedade reclama uma solução para os insensatos, que oscila contraditoriamente entre a humanização, decorrente dos lemas libertários da Revolução Francesa, e as medidas de caráter mais drástico, destinadas aos vagabundos, traidores, aos resistentes à fabulosa obra social que se pretende operar. Pinel, pois, acena para a recuperabilidade do louco e o isola, apoiado em questões de ordem técnica. Como primeiro e mais simbólico passo, as correntes são retiradas - a fim de restituir a liberdade que a loucura seqüestrou -, entrando para a história como o "gesto de Pinel". ${ }^{52}$

Entretanto, a liberdade da qual fala Pinel não significa o direito a sair do asilo, mas o direito ao tratamento na instituição autorizada para tanto. Mas isso implica um visível paradoxo. Se o louco é libertado das correntes e dos porões, não o é do hospício: é a liberdade intramuros, ou, como mais tarde diria Juliano Moreira apoiando-se em Marandon, "a ilusão da liberdade". ${ }^{53}$ Por que se apregoa a liberdade para todos, enquanto o louco, ao contrário, deve permanecer enclausurado? Porque a internação não é clausura: o alienado está privado de liberdade justamente por estar sob o julgo da alienação mental, porquanto deve ser isolado, pois o isolamento visa o seu tratamento e, portanto, a sua completa liberdade..$^{54}$

Pinel dá início ao primeiro asilo destinado exclusivamente aos alienados, o que se estende posteriormente à Salpêtrière, e isso possibilita a observação sistemática da loucura pelo saber médico: nasce a clínica psiquiátrica.

s. Quanto a esse aspecto é bastante ilustrativa a situação reproduzida por Foucault quando da visita de Couthon, o revolucionário. Este visitava Bicêtre com o objetivo de verificar se dentre os loucos que Pinel pretendia libertar não existiam suspeitos infiltrados e, assim, tentava interrogá-los, ao que recebia apenas injúrias e respostas desordenadas. Dirigiu-se então a Pinel: "'Cidadão, será que você mesmo não é louco, por querer libertar semelhantes animais?'" Pinel respondeu com calma: "'Cidadão, tenho certeza de que esses alienados são tão intratáveis somente porque são privados de ar e liberdade'". Ao que respondeu-lhe Couthon: "' - Pois bem, faça como quiser, mas receio que você acabará sendo vítima de sua própria presunçăo'" (Foucault, 1978:460).

s3. Juliano Moreira está defendendo a criaçẫo de um "epilepticômio" no qual, de acordo com Marandon, "é indispensável dar ao epiléptico, para mantê-lo resignado, a ilusão da liberdade" (MOREırA, 1905:182).

54 "- Sem este asilo, continuou o alienista, pouco poderia fazer; ele dá-me, porém, muito maior campo aos meus estudos". "- Muito maior, acrescentou o outro." O Alienista, p.21. 
Consolidado o projeto alienista, Pinel retorna à medicina geral, sua verdadeira paixão. Mas em seu redor deixa constituído um grupo de alienistas, dentre os quais destaca-se Esquirol, cuja obra é muito importante, embora no entendimento de certos autores (Bercherie, 1989; Birman, 1978) não tenha muita originalidade, tendo em vista que apenas desenvolve a nosografia e os pressupostos metodológicos de Pinel. Mas seu mérito está no fato de dedicar-se exclusivamente ao alienismo e direcionar toda a sua obra para esse tema. Porquanto a importância de Pinel esteja na fundação do alienismo, seja por sua atuação prática, institucional, com a transformação de Bicêtre e Salpêtrière, seja por sua nosografia, a de Esquirol está no desenvolvimento dessa obra, tanto em termos teóricos quanto práticos.

Esquirol desenvolve as mesmas linhas de tratamento iniciadas por Pinel, ou seja, a adoção do método expectante hipocrático, a cautela e o bom senso quanto à aplicação dos tratamentos orgânicos, e a imposição do asilamento e do tratamento moral. Adota, ainda, o termo 'asilo' para diferenciar a instituição psiquiátrica daquela do Hospital Geral, já adotada em sentido pejorativo pelo senso comum, como a instituição da marginalidade (Desviat, 1990). A mudança, no entanto, não diminui o estigma, pois, da mesma forma, o asilo torna-se a face da violência contra os loucos e os marginalizados.

O desenvolvimento da anatomopatologia e da clínica médica constitui-se obstáculo para o alienismo, pois permanece sendo um problema a existência de uma doença exclusivamente moral. Para (Birman, 1978:31-32), o conceito de doença moral significa, de certa forma, uma contradição entre os termos, já que a hegemonia do saber médico determina que, para existir doença, deve existir lesão. ${ }^{55}$

Assumindo a liderança da tradição teórica de Pinel, Esquirol deve responder a essa questão, já que parte dos alienistas volta-se para a tendência da busca da lesão originária, não acatando, portanto, o princípio pineliano de que a alienação tem uma causalidade exclusivamente moral. É assim que, em 1805, Esquirol reafirma considerar “principalmente as paixões como os sintomas mais essenciais e como os mais poderosos agentes terapêuticos contra a loucura" (apud Birman, 1978:50).

Em resposta aos anatomopatologistas, afirma: "esperam que nós vamos indicar a sede da loucura, que vamos fazer conhecer a natureza e a sede da lesão orgânica, do qual a loucura é a revelação. Nós estamos ainda bem longe deste fim” (ibid., p.56).

\$s A respeito de todo o conjunto desse debate entre as escolas somatista e psicológica, ou entre o físico e o moral, ver Bırman (1978), em que a idéia central é o deslocamento da questão da loucura do campo filosófico (moral) para o campo médico, na qual me apoiei em boa parte deste capítulo. 
Num primeiro momento, a prática alienista vem corroborar as assertivas de Esquirol, pois é o tratamento moral, e não os tratamentos físicos, que produz resultados para a cura dos alienados. Tal constatação permite a Esquirol afirmar que "para curar a loucura não é mais necessário conhecer a sua natureza, do que é necessário conhecer a natureza da dor para empregar com sucesso os calmantes e os sedativos" (ibid., p.62).

O tratamento moral, pois, apresenta resultados práticos, e sua aplicação depende mais fundamentalmente de uma correta administração do asilo, instituição que, na tradição pineliana, é, por si, terapêutica. É o próprio Esquirol a afirmar que "uma casa de alienados é um instrumento de cura; nas mãos de um hábil médico ela é o agente terapêutico mais poderoso contra as doenças mentais" (apud Castel, 1978a:61).

Posteriormente, no confronto com o somatismo, o psicologismo recebe dois duros golpes. O primeiro dá-se com a descrição das lesões cerebrais da paralisia geral progressiva, por Bayle, em 1822. Tal descoberta vem referendar a hipótese de uma origem lesional da alienação mental, o que, para a anatomopatologia, torna-se uma regra possível de ser estendida a todos os tipos de alienação. Assim, mesmo Esquirol curva-se diante da constatação da importante descoberta, introduzindo determinados arranjos em seu sistema explicativo, embora insistindo na preponderância das causas morais, inclusive para a constituição das lesões. O segundo golpe advém do fracasso que o tratamento moral passa a ter em momento posterior, uma vez que, para sua execução seriam necessários dedicação e esforço permanente, contínuo, uma observação caso a caso, tal como a preconiza e a exercita Esquirol.

Apesar de um determinado contingente de curas registradas, ocorre que os asilos têm grande número de internados e, com uma relação de 400 a 500 alienados por médico, o tratamento moral perde em sua eficácia (Desviat, 1990). Mas se existe o fato de o tratamento moral perder importância, por sua vez a anatomopatologia e a medicina clínica também não encontram os meios adequados para o tratamento da alienação, o que significa que o primeiro, embora com limitaçōes, continua sendo amplamente adotado. 


\section{O desvio maléfico e a torrente de $\operatorname{loucos}^{56}$}

A 'doutrina das degenerações' de Morel impõe nova reviravolta no saber sobre a alienação mental. Com ele o debate entre o físico e o moral encontram um termo comum, uma relação de interdependência. Para Nobre de Melo (1945:10) está em Morel a origem da atual orientação clínico-etiológica em psiquiatria, tanto pela introdução dos conceitos de 'predisposição e endogeneidade', posteriormente desenvolvidos por Magnan com a noção de 'constituição', quanto pelo desenvolvimento de um método original para classificar as doenças mentais, baseado não apenas na nosografia, mas, também, no acompanhamento da evolução da sintomatologia, do curso e da terminação. ${ }^{57}$.

Coincidentemente, na sessão da Sociedade Médico-Psicológica de Paris em que se discute informações referentes à aldeia de Geel, ${ }^{58}$ Morel anuncia ter elaborado "todo um livro a fim de ampliar o estudo das causas especiais da alienação, acrescentando nele as causas de degenerescências intelectuais, físicas e morais da espécie humana" (apud Castel, 1978a:261).

Nos estudos das causas especiais da alienaçăo, Morel retorna à metafísica, para a qual se inspira em Buchez, supondo um tipo primitivo ideal de humanidade, com todas as perfeições divinas, propriamente como descrito no Gênesis. ${ }^{59}$

Para Morel, em virtude do pecado original, o homem primitivo é condenado a lutar contra as hostilidades da natureza, tendo que adaptar-se ao meio que não se submete a suas imposições. Como castigo divino, este ser metafísico vai-se 'desviando

56 'Torrente de loucos' é o título da parte II de O Alienista, p.20, em que o dr. Simão Bacamarte estuda profundamente a loucura no meio social: "De todas as vilas e arraiais vizinhos afluíam loucos à Casa Verde. Eram furiosos, eram mansos, eram monomaníacos, era toda a família dos deserdados do espírito. Ao cabo de quatro meses, a Casa Verde era uma povoação. Năo bastaram os primeiros cubículos; mandou-se anexar uma galeria de mais trinta e sete".

5) Para Kronfetd (cf. Nobre de Melo, 1945:10), Morel não é apenas o criador do conceito de demência precoce, "mas o verdadeiro iniciador da investigação em esquizofrenia".

ss Aldeia belga que, por séculos, hospeda alienados com o objetivo de tentar a cura milagrosa realizada pela Santa Daphyne - Protetora dos Insanos -, que tem uma história bastante curiosa e serviu, nos debates franceses, para o surgimento do projeto de colônia de alienados. A respeito de Geel, ver Amarante (1982) e Pipparelu (1980).

$\rightarrow$ Significativa parte da abordagem aqui apresentada foi encontrada em NOBRE DE MEto (1945:146-147) e BerCHerie (1989:107-121), este último apoiado em GenIL-PerRin (1913). Cumpre ressaltar que Foucault (1977:177-178) atenta para o fato de que o conceito de degeneração já é utilizado desde o aparecimento da anatomia patológica, tomando-se por base uma concepção de Buffon, que o aplicava "aos indivíduos ou séries de indivíduos que se afastam de seu tipo específico". Como exemplo de uma pérola de etnocentrismo cultural e científico, Buffon, um dos pais da História Natural, faz a seguinte descrição dos habitantes da Guiné: "Os negros de Guiné têm o espírito extremamente limitado, e não têm memória; não podem contar além de três" (apud Melıo Moraes, 1855:171). 
maleficamente' do tipo primitivo ideal, de tal forma que tais desvios imprimem-se em sua constituição genética, dando assim origem às 'raças'. Mas o castigo continua: aquele ser primitivo, cujo maior dom era sua força moral e a predominância desta sobre o físico, ao ter-se submetido ao desejo da carne, ao ter-se permitido impor o físico sobre o moral, recebe uma 'degeneração moral' como marca impressa do seu desvio primário. O físico vai-se assim impondo sobre o moral e novos desvios vão surgindo nessas novas 'raças', que vão ultrapassando os limites do humano, caracterizando o processo mórbido. As 'degenerações' teriam um potencial hereditário - muito provavelmente pelo castigo divino - consideravelmente maior do que aquele que, até então, as leis da ciência reservam para a hereditariedade normal. Passando de pai para filho, as degeneraçōes terminam por ocasionar verdadeiras linhagens de degenerados; fatalidade insofismável que a humanidade deve reconhecer.

De acordo com Nobre de Melo, os fatores etiológicos das degenerações propostos por Morel podem ser devidos às intoxicações, especialmente o álcool, às influências do meio social (indústrias, profissões insalubres, miséria etc), a enfermidades anteriores ou de temperamentos mórbidos, à relação com o mal moral, a enfermidades congênitas ou adquiridas na infância ou, ainda, às influências hereditárias (Nobre de Melo, 1945:147-148).

As degenerações, transmitidas a agravadas hereditariamente, terminam por extinguir-se, por si só, ao ultrapassarem os limites de humanidade, pois, para Morel, o indivíduo degenerado perde a possibilidade de procriar, "quer por impotência funcional ou em razão do não desenvolvimento dos órgãos genitais, quer pela ausência congênita de faculdades prolíficas" (apud Nobre de Melo, 1945:148).

Dessa maneira, as degenerações levam os indivíduos a entregarem-se com maior facilidade ao mal moral que, ao mesmo tempo uma causa a um efeito, imprime novos atributos degenerados e, assim por diante, conformam um círculo vicioso que termina no inexorável fim da linhagem.

A teoria das degenerescências reconduz a psiquiatria à filosofia, à metafísica, à teologia e à antropologia, passando por incursōes no campo biológico, sede material da degeneração espiritual. O debate entre o físico e o moral fica, dessa forma, aparentemente resolvido, já que são instâncias interdependentes e ambas expressam, cada uma a seu modo, a presença da loucura.

A medicina mental aproxima-se da anatomopatologia por utilizar um conceito empregado por esta para designar um processo natural de desgaste do organismo humano, visível por intermédio de alterações anatômicas ou funcionais. Entretanto, como 
prenunciava Esquirol, o debate entre somatistas e psicologistas não fica ainda resolvido, pois em sua grade conceitual permanecem fortes as causas morais e sociais, como por exemplo as causas da dependência ao álcool, as influências sociais ou a relação com o mal moral.

No entanto, permanece a questão do por que o 'desvio maléfico' não é estendido a toda a humanidade, já que toda ela deveria pagar pelo pecado original? Pelo contrário, sua teoria vem justificar a necessária supremacia de determinadas raças sobre outras, de um lado os europeus e, de outro, os colonizados, ou em suas palavras, as 'classes superiores' a as 'classes declinantes'.

Para Castel, Morel elabora sua teoria, valendo-se de observações no proletariado da região de Ruão a das populações agrícolas, quando diretor do asilo de Saint-Yon (Castel, 1978a:263), o que o leva a construir um sistema explicativo para dar conta da situação de miséria a de doenças dessas populações. Assim, a explicação da miséria e das doenças é entendida como causa-efeito-causa, em decorrência do mal da degeneração.

A doutrina das degenerações provoca uma reviravolta porque, primeiro, retoma a discussão do princípio da cura dos alienados por meio do tratamento moral individualizado, sob o qual se funda o alienismo. O insucesso do tratamento moral, como provam os asilos repletos, possibilita que seja colocada em dúvida a sua eficácia. Mas, embora enfraquecido, ainda é o meio terapêutico que melhores resultados apresenta e, se a alienação é fruto de uma degeneração impressa na constituição do sujeito, não há como efetivamente tratá-la da mesma forma que a uma outra moléstia qualquer.

Entretanto, se o achado anatomopatológico de Bayle afasta ou, ao menos diminui, a importância da determinação moral na causa das alienações, a mesma importância ressurge com Morel, mas, desta vez, com significado diverso. A influência do mal moral não se exerce apenas sobre o sujeito em si, mas no padrão genético do homem. Portanto, se existe lesão física, esta é efeito a não causa. A causa primeira e maior é a degenerescência: ela é que determina as lesões e predisposições que, completando o círculo vicioso, agravam a primeira.

Finalmente, com base em tais princípios da teoria da degenerescência, o tratamento moral passa a assumir um caráter mais amplo, já que é apenas um paliativo em sua aplicação individual. Surge, desse modo, a idéia de sua universalização enquanto 'profilaxia preservadora', que objetiva a modificação das condições físicas, intelectuais e morais dos indivíduos que, contudo, não estão isolados entre si: é o conjunto de indivíduos (o elemento simples) que compõe a sociedade (o elemento complexo). 
É inspirado pela idéia predominante de "vincular a alienação mental à medicina geral" que Morel propõe uma "aplicação mais fecunda e mais universal do tratamento moral", isto é, a "moralização das massas" (apud Castel, 1978a:261262). Retorna-se, assim, a algumas questões: como o meio social causa a alienação?; o que é o mal moral?; como este causa as degenerações? Tratando-se de uma fatalidade, a alienação mental, como degenerescência, não pode ser tratada. Cumpre apenas adotar o método expectante, não mais hipocrático, no sentido de que este implicaria a busca da auto-organização, da cura, mas no sentido do termo final, ou seja, a extinção da espécie degenerada. Ou ainda, cumpre adotar o tratamento moral, ao menos no sentido de corrigir os desvios da degeneração e evitar o aparecimento de novas ordens de degenerescências, auxiliando os degenerados a defenderem-se contra eles mesmos, senão tratando, ao menos minimizando as conseqüências, e, no máximo de sua radicalidade, no sentido de prevenir o surgimento de novos degenerados.

Em suma, o tratamento moral deve ultrapassar a sua fase primitiva, individualizada, árdua a de poucos resultados, para tornar-se uma 'profilaxia preservadora', em oposição ao que a sociedade vem praticando até aqui - a 'profilaxia defensiva' -, isto é, o asilamento dos indivíduos portadores de alienação mental, que poucos resultados práticos apresenta.

Com o conceito de endogeneidade, Morel traz para a sociedade a premência de que sejam interrompidas as linhagens degeneradas, donde a origem da eugenia em psiquiatria. No entanto, consolida a noção de prevenção da alienação no meio social e moral, o que desloca a atuação do alienismo do interior do asilo para o meio social e político.

O asilo torna-se um lugar não apenas de isolamento terapêutico, no sentido pineliano, mas, também, de prevenção do mal que o contágio dos alienados pode causar para a contaminação da sociedade.

Desde então o termo degenerado, rico em significados éticos e morais abastardamento, perda moral, degradação -, torna-se sinônimo de alienação mental, seja na linguagem alienista, seja na laica. 'Alienado degenerado' é uma combinação entre termos, que não representa uma redundância, mas uma potencialização de valores negativos. 


\section{Do alienismo à psiquiatria contemporânea: alienação, degeneração e anormalidade}

Posteriormente, já no último quartel do século XIX, Magnan decide ocupar-se da teoria das degenerescências sobre a qual, e por extensão, constrói o conceito de 'predisposição'. E é por intermédio dele que essa teoria chega à Alemanha na qual, inicialmente com Griesinger, Krafft-Ebing e Kahlbaum, alcança o período de seu maior prestígio. Se é verdade que esse prestígio encontra limites com o surgimento da noção de 'unidades nosológicas' de Kraepelin, que passa a se opor ao conceito de degeneração, é também verdade que a teoria de Morel está na base da condição de possibilidade epistêmica do sistema de Kraepelin.

Para Nobre de Melo (1945:9), o princípio nosológico-clínico é o “eixo em torno do qual se acha edificada a totalidade da atual sistemática psiquiátrica. Por isso, Kraepelin deve ser considerado, com plena justiça, o verdadeiro criador da psiquiatria moderna".

Muitos outros autores contemporâneos admitem igual importância da contribuição de Kraepelin na base da psiquiatria "moderna" (Kaplan \& Sadock, 1984).

O mérito de Kraepelin está, primeiro, em fundar uma sistemática nosológica (em substituição à nosografia dos alienistas anteriores); segundo, porque, embora com termos distintos, distingue as alienações endógenas das exógenas, inclusive com a adoção do conceito de 'demência precoce' (que Bleuler vai posteriormente denominar de esquizofrenia); terceiro, porque adota uma classificação que vai da sintomatologia ao curso e à terminação; e quarto, porque o conceito de degeneração, tal como o admite, aponta para o caminho definitivo das investigaçōes quanto à hereditariedade (ibid., p.149), da qual, até os dias atuais, se ocupa a psiquiatria.

O princípio nosológico-clínico opera um novo arranjo interno no conjunto de aspectos relativos a uma doença, no qual são combinadas perspectivas diversas, tais como a etiologia, as condições de aparecimento da doença, a tendência à predisposição, o curso da moléstia, a sintomatologia, a perspectiva prognóstica, a idade, o sexo, os hábitos etc. Tal princípio permite pensar a doença como um conjunto combinado de aspectos não fortuitos, não acidentais, mas próprios da natureza de cada uma das unidades nosológicas.

Kahlbaun opera a transição que vai de Morel até Kraepelin, ultrapassando o princípio nosológico do primeiro, com sua nosologia que, não obstante, comporta ainda fatores heterogêneos como curso, sintomas, causas e idade. De acordo com Nobre de Melo (1945:10), os quatro grandes grupos de enfermidades de Kahlbaun são os seguintes: 
Vesânias, nas quais inclui a catatonia, guiada sobretudo pelo tipo de curso; as vesordias, em que se contêm as psicoses de prevalente cunho emocional, intelectual ou instintivo, como a melancolia e a paranóia; as disfrenias, onde incluem-se todas as psicoses sintomáticas; e as parafrenias, que compreendem as psicoses relacionadas à idade, as quais comportam ainda uma sub-divisão, conforme ocorram na infância (neofrenia), na juventude (hebefrenia), ou na velhice (presbiofrenia).

Kraepelin parte de Kahlbaun para fundar seu princípio nosológico-clínico, composto pela noção de unidades nosológicas, com uma compreensão longitudinal, diferenciada em grupos, de acordo com a etiologia, a sintomatologia, o curso, a terminação e a anatomopatologia de cada enfermidade (ibid., p.8-10). Sua classificação inclui as alterações mentais nos traumatismos cerebrais (delírio, epilepsia e defeitos psíquicos de origem traumática), nas encefalopatias orgânicas (tumores, encefalites etc.), nas intoxicações (intoxicações exógenas, agudas e crônicas, e intoxicações endógenas), nas enfermidades infecciosas (tifo, varíola, pneumonia etc.); a sífilis (sífilis cerebral e paralisia geral progressiva); os processos arterioscleróticos e de regressão (arteriosclerose cerebral, demência senil etc.); a epilepsia genuína; as esquizofrenias (demência precoce, parafrenias); a psicose maníaco-depressiva; as psicopatias (personalidades psicopáticas); as peações psicógenas; a paranóia e, finalmente, as oligofrenias (debilidade mental, imbecilidade, idiotia) (ibid., p.50).

Como é possível constatar nessa classificação, a nosologia e, conseqüentemente, a etiologia são muito mais importantes do que a nosografia. Os seis grupos iniciais são caracterizados por critérios exclusivamente etiológicos. As etiologias distinguem-se pelas causas internas e externas, em que as primeiras podem ser por predisposição geral (idade, sexo, raça, clima, condições gerais de vida, profissão) e por predisposição pessoal (hereditariedade, degenerescências, tipos hereditários, sinais degenerativos; educação); e as segundas por sua natureza somática ou psíquica (Portocarrero, 1980:57).

Com a consolidação do conceito de personalidades psicopáticas, Kraepelin insere importante novidade no saber psiquiátrico, que diz respeito à noção de ‘anormalidade'. Surgido como categoria médica no fim do século XIX, o conceito de anormalidade vem possibilitar a apropriação pelo saber médico de tudo aquilo que é percebido como não-normal. "Todo indisciplinável, e não só o louco, passa a ser considerado do ponto de vista da doença" (ibid., p.19). 
Eainda:

Na nosografia de Kraepelin as classes nosológicas caracterizam a especificidade etiológica tanto dos diversos tipos de doença mental, quanto das várias formas de anormalidade, manifesta sobretudo pelas personalidades psicopáticas, criminosos, instáveis, mentirosos, querelantes, constituindo um importante campo de pesquisa e de argumentação para o saber psiquiátrico. Neste sentido podemos afirmar uma mudança ao nível do saber, marcada pela passagem da concepção de doença mental - que fundamenta a psiquiatria do século XIX - para a concepção de anormalidade como forma de psicopatologia que constitui a novidade do discurso psiquiátrico do século XX. (ibid., p.20)

Para Portocarrero (ibid., p.58), a classificação de Kraepelin estabelece entidades nosográficas nas quais misturam-se conceitos de ordem moral com os relativos às afecções orgânicas, que se explicitam e se entrelaçam na etiologia e sintomatologia da doença. O modelo de Kraepelin apresenta um plano de trabalho,

cujo método se esforça em ser médico, que se pretende diferente dos métodos das ciências naturais, até então utilizados na formação do discurso teórico da medicina mental. Porém, seu método médico consiste em observar o curso natural das perturbações mórbidas, tomar minuciosamente seus sintomas, de acordo com a ordem de aparição; observar o seu desenvolvimento espontâneo e sua terminação natural, para poder distinguir o essencial do acessório. É, portanto, o mesmo procedimento comparativo das ciências naturais aplicado à psiquiatria, ou seja, uma outra modalidade do mesmo método, embora afirme não aceitá-lo.

No mesmo sentido, para Oliveira (1994:2-3),

...em seus primórdios, a psiquiatria - como toda a medicina oitocentista praticamente restringe-se a um processo de cuidadosa observação, descrição e classificação (e subclassificação: em gêneros, famílias, espécies etc.) das chamadas 'entidades nosológicas', desta forma reificadas. (...) Com o que, os 200 anos de psiquiatria que então transcorrem se restringem, a rigor e em síntese, a 200 anos de intermináveis discussões nosográficas, nas quais sistemas classificatórios se contrapõem a outros sistemas classificatórios, e onde o que marca os grandes nomes da história desta disciplina - como Esquirol, Morel, Kraepelin etc. - é sempre a criação de um novo sistema nosográfico (para a cunhagem de novos termos, mudanças nas definições, reagrupamento das classes no interior do sistema etc.). 


\section{Em torno de História da Loucura}

Cumpre ressaltar que a interpretação de Foucault para com a História da Loucura, mais precisamente para com Descartes, não é aceita sem restrições. Para Derrida, por exemplo, como nos apresenta Bezerra (1992:119),

Foucault teria retirado de Descartes mais do que o texto das Meditações permitia. Segundo este autor, a loucura não recebe de fato nenhum tratamento específico na primeira Meditação, nem é submetida a nenhuma exclusão particular. Foucault é que teria interpretado o silêncio de Descartes sobre a loucura como o signo de uma exterioridade absoluta entre esta e a razão. Mais ainda: para Derrida, esse silêncio, ao contrário, prepararia a retomada da questão da loucura com a hipótese do Cênio Maligno. Segundo ele, Descartes procuraria demonstrar na segunda Meditação que o cogito sum permanece verdadeiro mesmo se estou enlouquecido pelo Gênio Maligno. 'Louco ou não, cogito'. 'Existe um valor e um sentido do cogito como existência, que escapam à alternativa de uma loucura e de uma razão determinadas'.

Não é o caso de se deter exclusivamente sobre essa discussão, mas cumpre atentar para a natureza da análise das 'práticas discursivas' e dos saberes construída por Foucault (1972) em A Arqueologia do Saber, no qual o valor dos enunciados não está apenas e necessariamente no enunciado, mas no que ele deixa de enunciar. Para Roberto Machado, a polêmica é sobretudo metodológica:

é que, para ele (Foucault), não se deve reduzir o discurso a texto cujos traços seriam lidos a partir de sua estrutura interna como se nada existisse fora dele. O discurso é uma prática, um acontecimento e quando é considerado como tal, isto é, quando não se busca seu sentido ou sua estrutura, lança o investigador para fora do discurso. A arqueologia relaciona diferentes discursos e, não se limitando a este nível, articula as 'formaçōes discursivas' com práticas econômicas, políticas e sociais. (Machado, 1982:62)

Ou, como lembra Pelbart (1989:64), História da Loucura "trata de uma 'arqueologia da percepção'" e não "da experiência vivida". O autor desenvolve ainda um segundo argumento, que diz respeito a recusa da hipótese repressiva implícita nas críticas ao livro, em razão de uma compreensão, para ele equivocada, de que existiria uma experiência originária, primitiva, uma essência permanente na loucura, que teria 
sido reprimida pela história. Tais interpretações são dadas por Michel Serres, que vê em História da Loucura a voz da loucura 'em si', as chaves da loucura, e por Derrida, no lado oposto, "que contesta a possibilidade de fazer a história desse silêncio" (Pelbart, 1989: 63-64).

Mas se em Descartes a loucura/desrazão está ou não colocada fora da razão, o certo é que a loucura é percebida como socialmente perigosa, despossuída de coerência, permeada pelo erro. E, de fato, pelo que se constata da Grande Internação, a solução social para a loucura é a reclusão.

De qualquer forma, a leitura que Foucault faz de Descartes não é totalmente isolada. Para Beyssade, em Descartes,

a dúvida sobre as coisas sensíveis, parcial quando não é motivada pelos erros de percepção, atinge sua plenitude quando é questionada a própria existência do objeto recebido: a loucura, aquela cujos efeitos vemos sobre o outro, e sobretudo o sonho, experiência que temos todas as noites, fazem sombra ao mundo cotidiano e às suas particularidades mais familiares. (Beyssade, 1974:95)

E mais adiante (ibid., p.96):

Uma ficção encerra a dúvida, a do Gênio Maligno, tão astuto e enganador quanto poderoso, espantalho forjado pela imaginação a fim de manter a decisão de duvidar, justificada daqui por diante por razōes muito fortes e maduramente consideradas, contra a usura do tempo e o retomo subreptício das antigas opiniōes.

E, finalmente, lembrando que Descartes insere na língua francesa a palavra 'consciência',

que na época tinha ares de latinismo, definindo como pensamento tudo o que é consciente, a vontade, a imaginação, até a sensação, caso se trate do pensamento de ver e não de uma modificação do olho ou do cérebro, assim como a idéia de entendimento. (ibid., p.97)

Quanto à Gauchet e Swain, dentre outros aspectos criticados na obra de Foucault, está o fato de que

ao invés de signo de exclusão, o asilo refletiria a utopia igualitária dos revolucionários e a noção disseminada entre eles de que a sociedade e o ambiente modelam o homem. Daí a necessidade de que 'as paredes fos- 
sem terapêuticas' (Esquirol) e onde a hierarquia, a arquitetura e a disciplina pudessem servir ao objetivo de resgatar para uma igualdade de fato aqueles que somente a possuíam como direito. (apud Bezerra, 1992:113-126)

Aqui coloca-se a questão entre 'práticas discursivas' e práticas políticas, com seus aspectos correlacionados à função e ao papel das ciências e saberes na normatização e na ordenação social, de 'instrumentos tecnocientíficos de poder', aspectos nucleares na obra de Foucault, que contribuíram notavelmente para o campo da epistemologia e da filosofia das ciências. Ainda hoje a psiquiatria contemporânea justifica muitas de suas práticas totalitárias sob a égide do tratamento e da cura das doenças, e é certo que muitos o fazem com convicção e não por perversidade ou mero oportunismo.

É correto dizer que o asilo reflete a utopia igualitária dos revolucionários quando passam a considerar a loucura curável; mas é também verdade que, durante o Antigo Regime, qualquer um poderia ser internado no Hospital Geral pelas lettres de cachet $\mathrm{e}$ que, após a Declaração dos Direitos do Homem e do Cidadão, o mesmo não pode mais ocorrer: a partir de agora, a internação dos loucos só se torna possível como ato terapêutico, e é a Pinel que cabe a tarefa de conceituar a natureza desse ato.

E, mesmo após o gesto de Pinel, a reclusão continua a ser a prática dominante, mesmo que justificada pela necessidade do tratamento, e mesmo que este seja justificado como ato humanitário e uma forma de resgatar a possibilidade de cura/resgate do livre-arbítrio.

No entanto, Pelbart (1989:57-74) sublinha a "ambigüidade" de Foucault para com os conceitos de loucura e desrazão (no sentido de que aparentemente são adotados como sinônimos). Para o autor, essa seria a causa da aparentemente inexplicável modificação do título original da obra Folie et Déraison - histoire de la folie à l'âge classique, que na segunda edição torna-se apenas Histoire de la Folie à l'âge Classique. Uma resposta, talvez, como também reconhece Pelbart, pode ser encontrada em Machado ao atentar para que

o termo desrazão é utilizado em pelo menos duas acepções diferentes: uma coisa é a desrazão clássica, diz ele, 'que é produto do Grande Enclausuramento, e portanto um objeto construído', outra coisa é a 'desrazão positiva que vai servir de princípio de julgamento da psiquiatria e da racionalidade clássica que Ihe preexiste e é por ela reprimida'. (Pelbart, 1989:62) 
De qualquer forma, para Pelbart, a questão não é solucionada, uma vez que essa é uma tese altamente polêmica:

Ela equivale a dizer que uma experiência fundamental da loucura, reprimida pela história, persiste por trás da história ou por debaixo dela. Como se, para além das manifestações da loucura enquanto produções históricas, sociais, teórico-científicas existisse, num outro nível, uma outra experiência, mais originária, que teria sido recoberta e reprimida por esta. (idem)

O que parece problemático, em primeiro lugar, é falar de loucura - mesmo que ainda não se fale em doença mental -, como se fosse uma entidade em si, o que, em última instância, seria acatar a tese de que loucura e doença mental são exatamente a mesma coisa. Ou, em outras palavras, seria concordar com o fato de que a apropriação da loucura pelo discurso médico seja um processo que simplesmente traduz a maior competência da medicina em decifrar aquilo que, por ordem de seu estágio primitivo anterior, não era possível ainda reconhecer. Falar que a loucura tenha existido enquanto experiências concretas de sujeitos, é possível de ser entendido. O que não o é, entretanto, e isto é absolutamente distinto, é falar da busca de uma essência própria da loucura que, antes de sua medicalização, era uma outra coisa.

Um outro aspecto refere-se à institucionalização daquilo que se convencionou, cultural ou cientificamente, como loucura. Ora, a experiência, não da loucura tomada abstratamente, mas do louco, não é modificada pela experiência da reclusão? Da mesma forma, não é também modificada pela forma pela qual as instituições, a cultura, a tecnociência e as pessoas lidam com os objetos e os sujeitos? Charcot não "produzia efetivamente" a crise de histeria que descrevia? (Foucault, 1979:123). Esta é uma importante observação que permitirá a Basaglia deter-se não sobre a loucura, mas sobre o sujeito de sua experiência. Porém, essa é uma questão a ser retomada mais adiante...

Para Machado (1979:xi), em História da Loucura,

quando se tratou de analisar historicamente as condições de possibilidade da psiquiatria, o próprio desenvolvimento da pesquisa apontou o saber sobre o louco - diretamente articulado com as práticas institucionais do internamento - como mais relevante do que o saber teórico sobre a loucura (...). Além disso, Histoire de le Folie também não se limita no nível do discurso para dar conta da formação histórica da psiquiatria. Ao contrário, chega mesmo a privilegiar o estudo dos espaços institucionais de controle do louco e dos saberes a eles intrinsecamente relacionados descobrindo, 
inclusive, desde a época clássica, uma heterogeneidade entre os discursos teóricos - sobretudo médicos - sobre a loucura e as relações que se estabelecem nesses lugares de reclusāo. Foi analisando os saberes teóricos, mas sobretudo as práticas de internamento e as instâncias sociais -família, Igreja, justiça, medicina - a elas relacionadas e, finalmente, generalizando a análise até as causas econômicas e sociais das modificações institucionais que Histoire de la Folie foi capaz de explicar as condições de possibilidades históricas da psiquiatria. (Machado, 1981:59)

Para Portocarrero (1990:61),

Foucault afirma, em História da Loucura, que a designação de loucura e que a conseqüente exclusão da sociedade não dependem de uma ciência médica, mas de uma 'percepção' do indivíduo como ser social, dispersa e produzida por diversas instituições como a polícia, a justiça e a família, a partir de critérios que dizem respeito à transgressão das normas.

Enfim, com História da Loucura Foucault inaugura a possibilidade de entendermos que o conhecimento da racionalidade do objeto científico, sobretudo quando se trata de um objeto cultural, e não da natureza, não pode ser julgado ou avaliado a partir da racionalidade da ciência. Eis porque a diferença entre loucura e razão é sobretudo ética, e não médica. ${ }^{60}$ seminário organizado por Elisabeth Roudinesco, em comemoração aos 30 anos da publicação do livro (Roudinesco et al., 1994). 


\section{Capítulo 3}

\section{Franco Basaglia: \\ novas histórias para a desinstitucionalização}

\section{Uma aventura no manicômio: $o$ homem e a serpente ${ }^{61}$}

Em 1961 Franco Basaglia assume a direção do Hospital Provincial Psiquiátrico de Gorizia, no extremo norte da Itália. Vindo de Padova, onde trabalhava na Universidade, em contexto completamente diferente e distante da verdadeira assistência pública, sofre um grave impacto ao deparar-se com a realidade de um manicômio, que é assim relatado por Dell'Acqua (1980:39):

A primeira vez que entrou neste hospital, e era sempre ele mesmo a contar isso, viu os internos fechados à chave dentro dos pavilhöes a nas celas de isolamento, e recordou-se de quando estava na prisão. Então, pensou que deveria usar todo o seu poder de diretor para melhorar as condições de vida destas pessoas.

A realidade dos manicômios não contaminava os assépticos gabinetes universitários ou as enfermarias da 'clínica psiquiátrica', nem penetrava nos cursos de psiquiatria. Absolutamente alheios à prática assistencial efetivamente exercitada na Itália, de caráter predominantemente manicomial, alheios até mesmo às transformações que vinham ocorrendo em outros países europeus, a exemplo da Inglaterra e da França, os setores universitários simplesmente desconheciam o interior dos manicômios.

Sirvo-me, aqui, da idéia do ensaio publicado em História, Ciências, Saúde - Manguinhos, 1(1):6177, no qual ressalto a importância do termo 'aventura', com freqüência utilizado para desqualificar a importância da experiência de Basaglia, mas que, inversamente, e de acordo com uma formulação do próprio, postula um significado de invenção e superação das verdades científicas (AMARANTE, 1994b). No mesmo sentido, Serres nos fala de uma "antropologia das ciências", que contribui para nossa aventura contemporânea, possibilitando um "terceiro-mundo ou uma terceira-ordem do pensamento", que "tratam de preparar as respostas especulativas e práticas à interrogação e à inquietação maiores de nosso tempo: não conquistar absolutamente os homens e o mundo, porém, juntos, salvaguardá-los" (SERRES, 1990b:2). 
Este primeiro contato impõe-lhe uma identificação com a situação dos internos, que é estabelecida a partir da sua própria experiência como objeto da violência quando 'partigiano', que o fez permanecer na prisão até o fim da guerra. Uma fábula vem, de pronto, à mente de Basaglia, a nela permanece como uma referência ao longo de toda a sua trajetória que, por tal importância, vale a pena reproduzi-la:

Uma fábula oriental conta a história de um homem em cuja boca, enquanto ele dormia, entrou uma serpente. A serpente chegou ao seu estômago, onde se alojou e onde passou a impor ao homem a sua vontade, privando-o assim da liberdade. O homem estava à mercê da serpente: já não se pertencia. Até que uma manhã o homem sente que a serpente havia partido e que era livre de novo. Então dá-se conta de que não sabe o que fazer da sua liberdade: 'No longo período de domínio absoluto da serpente, ele se habituara de tal maneira a submeter à vontade dela a sua vontade, aos desejos dela os seus desejos e aos impulsos dela os seus impulsos, que havia perdido a capacidade de desejar, de tender para qualquer coisa e de agir autonomamente.' 'Em vez de liberdade ele encontrara o vazio', porque 'junto com a serpente saíra a sua nova essência, adquirida no cativeiro', e não the restava mais do que reconquistar pouco a pouco o antigo conteúdo humano de sua vida. ${ }^{62}$

Basaglia estabelece uma analogia entre essa fábula e a condição dos doentes mentais no manicômio, na qual o inimigo - a serpente - que os destrói e os submete, representa o saber psiquiátrico. É certo que a fábula toca-o também por sua antiga condição de prisioneiro, que o ensinou a lutar e a valorizar a vida e a liberdade. $E$ complementa:

Mas nosso encontro com o doente mental também nos mostrou que, nesta sociedade, somos todos escravos da serpente, e que se não tentarmos destruí-la ou vomitá-la, nunca veremos o tempo da reconquista do conteúdo humano de nossa vida. ${ }^{63}$

Q A instituição negada, p.132. A fábula é relatada por Jurij Davydov, 1966. Il lavoro e la libertà, Torino: Einaudi. In: Corpo e Istituzione (considerazioni antropologiche e psicopatologiche in tema di psichiatria istituzionale), escrito em 1967 (BASAGLIA, Franco, 1981:428-441), a fábula é recontada na página 435. DE LEONARDIS (1990:16), chama a atenção para a analogia e as diferenças de outra parábola, "similar, mas com êxito muito diverso, o 'enigma' da serpente e do pastor de Zaratustra". " - O pastor, porém, mordeu, como lhe aconselhava meu grito; mordeu uma boa mordida! Bem longe cuspiu a cabeça da serpente - e levantou-se de um salto". "Não mais pastor, não mais homem - um transfigurado, um iluminado, que 'ria'! Nunca ainda sobre a terra riu um homem, como ele ria" (NietzSCHE, 1978:245). 
Abalado com a situação do manicômio, Basaglia procura conhecer melhor as experiências de reformas psiquiátricas, notadamente as de comunidades terapêuticas e de psicoterapia institucional, com o objetivo de aplicá-las em Gorizia. Contudo, a dura e refratária realidade institucional, somada ao 'insucesso' daquelas iniciativas, muito cedo contribuem para que se inicie uma reflexão mais profunda sobre a real possibilidade das reformas iminentemente asilares. Para Rotelli (1994), é ainda graças a um certo atraso em iniciar reformas psiquiátricas em território italiano que se torna possível refletir sobre a viabilidade das experiências anteriores e, assim, poder extrair frutos de suas falências. Dessa maneira, para Basaglia

estas experiências, que sob uma base de paridade de direitos assistenciais de todos os cidadãos, partem de uma primeira liberalização dos hospitais psiquiátricos até a constituição de hospitais abertos, têm demonstrado, no passar de poucos anos, resultados tais que estimularam o início de nossa 'aventura em psiquiatria'. (Basaglia, 1981:261) ${ }^{64}$

Essa aventura tem muitos atores, cenários e conceitos. ${ }^{65}$ Nesse sentido, deve-se fazer uma advertência: de forma artificial, tão-somente para atender ao objetivo de sistematizar os principais conceitos, procurou-se delinear algumas das linhas básicas das contribuições trazidas por Franco Basaglia. Procura-se trabalhar o conceito pela sua importância, tanto propriamente teórica quanto pela ordem de aparecimento cronológico, o que não chega a significar grande problema, já que a própria evolução dessa trajetória está intimamente ligada aos conceitos que emergem em relação à sua operacionalidade prática. A adoção de tal critério não deve levar ao entendimento de que os conceitos e temas estejam, em sua origem, apresentados dessa mesma forma, nem que possam ser rigorosamente extraídos do contexto em que foram elaborados. Portanto, os conceitos se entrecruzam, relacionam-se entre si em um mesmo corpo teórico e, mais que isso, estão relacionados a questões concretas da prática que Basaglia está, em cada momento, experimentando e sobre ela refletindo. O conceito mais geral, que pode servir de base e linha condutora para o conjunto do texto, é o de desinstitucionalização que, desde o início, imprime as bases teórico-metodológicas do projeto de transformações.

64 La 'comunità terapeutica' come base di un servizio psichiatrico - realtà a prospettive, escrito em 1965 (BASAGLIA, Franco, 1981). A maioria dos textos de Basaglia, citados neste capítulo, está publicada nos dois volumes de Basaglia Scritti, organizados por BASAGlia, Franca O. (1981, 1982). Com o objetivo de facilitar a identificação de cada um deles, a partir daqui, os mesmos serão referidos em nota de rodapé.

6s Para um estudo sob o aspecto tanto histórico quanto conceitual da trajetória de Basaglia e das experiências de Gorizia e Trieste, ver Nićcio (1989) e BarRos (1994). 


\section{A renúncia à vocação terapêutica: a instituição negada}

Nos primeiros momentos do projeto de transformação no Hospital de Gorizia, Basaglia busca referências práticas e teóricas em Tosquelles (psicoterapia institucional) e Maxwell Jones (comunidade terapêutica) (Slavich, 1989). De fato, nesse primeiro momento, o que Basaglia pretende, em suas próprias palavras, é a "transformação do manicômio em um hospital de cura", ${ }^{66}$ a ser viabilizada, basicamente, pela introdução de transformações no âmbito intra-hospitalar que tornassem possível o envolvimento de todos, "pacientes, médicos e pessoal", "numa mesma crise e, nela, encontrar a sua base humana comum". ${ }^{67}$ No entanto, egresso do meio acadêmico, Basaglia conserva dele uma tradição que, à época, e na Itália, representava um pensamento de vanguarda: a fenomenologia existencial. Para Franca,

o pensamento fenomenológico existencial, surgido como resposta à desumanização na qual havia entrado a Europa durante a Segunda Guerra Mundial, colocava em discussão o problema do homem, não mais como entidade abstrata, definivel segundo um sistema de categorias fechadas, mas como sujeito-objeto de um sofrimento social (...) A fenomenologia existencial poderia ser, enfim, um primeiro instrumento de desmascaramento do terreno ideológico sobre o qual a ciência se funda, reivindicando a autonomia e a compreensão do dado, através do conhecimento das diversas modalidades do seu existir. (Basaglia, Franca O., 1981:xx-xxi)

Um contato nessas bases, com a fenomenologia, poderia findar-se em sua utilidade para a psicopatologia, mas não no que dizia respeito à démarche epistemológica que então se iniciava em Basaglia.

Ao mesmo tempo em que os primeiros anos dessa tentativa são suficientes para demonstrar o caráter absolutamente superficial de tal ordem de medidas, isto é, de medidas reformadoras do asilo, Basaglia toma contato com a produção de Foucault e Goffman, que vem somar-se à sua formação fenomenológico-existencialista. Desde então, História da Loucura e Asyluns ${ }^{68}$ tornam-se referências marcantes e decisivas para sua inflexão em um projeto de desconstrução do saber e das instituições psiquiátricas.

66 La distruzione dell'ospedale psichiatrico come luogo di istituzionalizzazione - mortificazione e libertà dello 'spazio chius' - considerazioni sul sistema 'open door', escrito em 1964 (BASAGLiA, Franco, 1981:255).

( Ibid., p.258.

68 Asyluns foi publicado no Brasil sob o título de Manicômios, Prisōes e Conventos. 
Essas são duas referências de forte presença nos primeiros escritos, que abrem a perspectiva crítica quanto à função da instituição psiquiátrica e contribuem para redimensionar o projeto de transformação.

As reflexões voltam-se para o projeto institucional da psiquiatria reconhecendo, com base em Foucault, que:

a liberdade da qual falava Pinel estava conclusa em um espaço fechado, entregue às mãos do legislador e do médico, que deviam dosá-la e tutelála. (...) O psiquiatra parece, de fato, e apenas hoje, descobrir que o primeiro passo em busca da cura do doente é o retorno à liberdade da qual ele mesmo o havia privado. ${ }^{69}$

A partir daí, acentua-se o percurso de reflexão sobre a psiquiatria como instrumento de saber e poder, de controle e segregação, que havia sido iniciado com sua aproximação à fenomenologia-existencial.

Nesse primeiro ensaio, com o qual Basaglia inicia sua fase de crítica institucional, é significativa a referência ao manifesto dos surrealistas franceses aos diretores dos manicômios, utilizada como epígrafe do texto:

De manhã, na hora da visita, quando sem qualquer léxico, tentarem comunicar-se com estes homens, recordem e reconheçam que, no seu confronto, vocês têm uma só superioridade: a força. ${ }^{70}$

Para Franca Basaglia, a estratégia da "negação da psiquiatria enquanto ideologia" nasce desse "encontro com a prática psiquiátrica" (isto é, com a realidade diretamente conseqüente às definições, aos instrumentos e às finalidades da psiquiatria como ciência) (Basaglia, Franca O., 1981:xxii).

Nega-se a psiquiatria como ideologia...

na medida em que percebe-se que esta tende a fornecer justificativas teóricas e respostas práticas a uma realidade que a própria ciência contribui para produzir, nas formas mais adequadas à conservação do sistema em que está inserida. (Basaglia, Franca O., 1981:xxii)

$\oplus$ La distruzione dell'ospedale psichiatrico come luogo di istituzionalizzazione - mortificazione e libertà dello 'spazio chius' - considerazioni sul sistema 'open door' (BASAGLIA, Franco, 1981:249).

t La distruzione dell'ospedale psichiatrico come luogo di istituzionalizzazione - mortificazione e libertà dello 'spazio chius' - considerazioni sul sistema 'open door' (BASAGLIA, Franco, 1981). O texto em questão foi escrito por Antonin Artaud. 
Em Un problema di psichiatria istituzionale - l'esclusione come categoria sociopsichiatrica, ${ }^{71}$ toma corpo a crítica à cientificidade da psiquiatria:

A psiquiatria depara-se hoje a confrontar-se com uma realidade que está colocada em discussão desde quando - superado o impasse da dualidade cartesiana - o homem se revela objeto em um mundo objetual, mas contemporaneamente sujeito de todas as suas possibilidades. (..) A psiquiatria clássica de fato está limitada à definição das síndromes nas quais o doente, extraído da sua realidade e retirado do contexto social em que vive, vem etiquetado, 'constrangido' a aderir a uma doença abstrata, simbólica e, enquanto tal, ideológica. ${ }^{72}$

É importante observar que o 'doente' ou a 'doença' não estão sendo negadas como existência. O que está sendo colocado em negação é o conceito de doença mental como construção teórica.

Apoiando-se nas Reflexões sobre a Questão Judia, de Sartre, Basaglia compreende que o exercício da exclusão dos enfermos mentais é uma escolha deliberada, que não pode ser considerada pessoal, mas um investimento global do ser-no-mundo, "a escolha de um mundo maniqueísta onde a parte do mal é sempre reputada como sendo do outro, no caso, do excluído; onde apenas neste excluir afirmo minha força e me diferencio". ${ }^{73}$

Basaglia entende que esta escolha inscreve-se na dialética servo-senhor, tal como desenvolvida por Hegel na 'fenomenologia do espírito', que torna-se-lhe útil para refletir sobre a objetivação que o senhor-psiquiatra faz do servo-interno, utilizando como critério e instrumento desta objetivação, o saber psiquiátrico. Visto de outra forma, a condição de excluído, à qual é delegado o doente mental, impõe-lhe uma série de outras conseqüências que não podem ser identificadas como decorrentes de sua condição de enfermo. E se é a psiquiatria que exerce este mandato, é esta que deve ser questionada e não o enfermo.

Motivado pelo ensaio O que é a Literatura?, também de Sartre, Basaglia publica Che cos'è la psichiatria? ${ }^{74}$ Assim, inspirado em Sartre, para quem "as ideologias são liberdade enquanto se fazem, opressão quando são feitas", Basaglia extrai a idéia de

Escrito em 1966, em colaboração com BASAGLIA, Franca O. (1981:309-328).

lbid., p.309.

Ibid, p.311.

Che cos'è la psichiatria?, publicada em 1967, é a primeira coletânea organizada por BASAGUA, Franco (1981:384-393). 
que a prática de fixar-se sobre esquemas preestabelecidos, que nascem como recusa de uma realidade dada, deve encontrar nesta mesma realidade o sentido do renovar-se contínuo, para não transmutar-se em opressão de si mesmo. ${ }^{75} \mathrm{Na}$ prática isso significa afastar-se da "utopia da reaprendizagem, guiada pelos princípios do tratamento moral"76 exercitados pela comunidade terapêutica a pela psicoterapia institucional, que partem do pressuposto da liberdade concedida para um projeto de construção da liberdade. ${ }^{77}$

A pergunta 'o que é a psiquiatria?', propositadamente 'provocativa', nasce do estado de mal-estar real no qual se encontra a psiquiatria que, no confronto com o seu objeto, não pôde mais que definir a diversidade e a incompreensibilidade em simples e concreta estigmatização social. A discussão do método científico torna-se o escopo desta obra que, tendo como base a pesquisa psiquiátrica, no contexto ainda das reflexões de Sartre em Crítica à Razão Dialética, atenta para o fato de que a "distância do pesquisador do terreno da própria pesquisa é particularmente significativa no caso da psiquiatria", o que determina ao psiquiatra afastar-se do doente, de seu sofrimento e de sua condição real de institucionalizado. Ao fim desse processo, o psiquiatra termina por interpretar ideologicamente a doença sem considerar as circunstâncias institucionais ou, como propõe Goffman (1974), "as contingências de carreira".

Refletindo as circunstâncias do período final da experiência de Gorizia, Che $\cos ^{\prime}$ è la psichiatria? traz algumas advertências quanto às limitações da comunidade terapêutica e modelos análogos. É entendido que tais modelos, embora possam constituir um passo necessário para a transformação do hospital psiquiátrico, não podem ser considerados uma meta final; não podem ser tomados como uma resposta/solução técnica ao problema da doença mental. A mesma advertência é feita em relação ao que Basaglia começa a denominar, a partir daqui, de a "nova psiquiatria". ${ }^{78}$ Esta passa a ser definida como um conjunto de técnicas de modernização do saber psiquiátrico,

Ibid., p.384.

Basaclaa, Franco \& Galloo (1991:28).

A esse respeito, ver MAURI (1983).

Apesar de o conteúdo crítico dessa expressão 'nova psiquiatria', dela me tenho utilizado (AMARANTE, 1994a) com o objetivo de estabelecer uma analogia com a instituição inventada (ROTELL, 1989) - o que será abordado mais adiante - ou com a psiquiatria da desinstitucionalização (DE LEONARDIs, 1987), na medida em que considero correto insistir no pressuposto de uma nova psiquiatria calcada nesta corrente da desinstitucionalização, da mesma forma que esta última expressão é utilizada com novo sentido por Rotelli, Venturini, Dell'Acqua, De Leonardis, dentre outros. 
que, fundadas basicamente na abordagem psicoterapêutica a nas 'relações sociais' da psiquiatria, adotam os mesmos esquemas positivistas que renovam o ideal da vocação terapêutica, a camuflar suas verdadeiras funçōes sociais.

O desenvolvimento do trabalho em Gorizia volta-se, então, para a estratégia de refutar as transformaçōes asilares, o 'reformismo psiquiátrico', a busca de novas e modernizantes soluções para a manutenção da instituição asilar, ou a procura de soluções 'exclusivamente técnicas' para lidar com a doença mental. Em A Instituição Negada, Basaglia afirma que a ação de transformação em Gorizia

só pode prosseguir no sentido de uma dimensão negativa que é, em si, destruição e ao mesmo tempo superação. Destruição e superação que vão além do sistema coercitivo-carcerário das instituições psiquiátricas e do sistema ideológico da psiquiatria enquanto ciência para entrar no terreno da violência e da exclusão do sistema sociopolítico, negando-se a se deixar instrumentalizar por aquilo que quer negar. ${ }^{79}$

A 'negação da psiquiatria enquanto ideologia' vai muito além de uma mera recusa político-ideológica de aceitação do construto da doença mental. Para Basaglia:

A negação de um sistema é a resultante de uma desestruturação, de um questionamento do campo de ação sobre o qual se age. É este o caso da crise do sistema psiquiátrico enquanto sistema científico e enquanto sistema institucional, ao mesmo tempo que vem sendo desestruturado e questionado desde que nos conscientizamos do significado desse campo específico, particular, no qual se opera. Isso significa que, em contato com a realidade institucional - e em clara contradição com as teorias tecnocientíficas -, evidenciaram-se elementos que remetem a mecanismos estranhos à doença e à sua cura. Diante de tal constatação era impossível evitar a crise das teorias científicas sobre o conceito de doença, assim como das instituições sobre as quais elas fundam suas ações terapêuticas. ${ }^{80}$

Dessa forma, a negação tem muitas dimensões e ângulos:

Negação da instituição manicomial; da psiquiatria enquanto ciência; do doente mental como resultado de uma doença incompreensível, do papel de poder puro do psiquiatra em relação ao paciente; do seu mandato

79 A instituição negada, p.131. Publicada originalmente em 1968, é a segunda coletânea organizada por Franco Basaglia et al. com reflexões decorrentes da experiência de Gorizia. 
social, exclusivamente de custódia; do papel regressivo do doente, colocado junto à cultura da doença; a negação e a denúncia da violência à qual o doente é sujeito dentro e fora da instituição (...). ${ }^{81}$

A realidade do manicômio é extremamente dramática para permitir a ilusão de que a solução esteja restrita, tão-somente, a uma resposta técnica. Não parecem haver soluções de cunho exclusivamente científico para pessoas relegadas à violência institucional psiquiátrica, pois, ao que torna-se flagrante, não estão confinadas nesse espaço para serem efetivamente curadas, como pretendia Pinel. O manicômio é exatamente o espaço que a sociedade reserva para os loucos, e isso não quer dizer, em absoluto, que é ela que produz a doença. Mas que esta não deseja, ou não sabe, conviver com eles. A opção está em se continuar buscando uma explicação e, portanto, uma cura para o doente mental objetivado como materialidade opaca, "prisioneiro do território psiquiátrico", ou "em recusar este mandato social dialetizando, no plano prático, tal negação: negar o ato terapêutico..." ${ }^{82}$

É desse modo que, em dado momento, o trabalho em Gorizia concentra-se em três grandes linhas de intervenção que, na prática, estão cotidianamente presentes nas assembléias, nas discussões com os técnicos, nos contatos com os familiares e a sociedade: a origem e o pertencimento de classe dos internos do hospital; a pretensão de neutralidade e de produção de verdade das ciências; a função social de tutela e controle social da psiquiatria, do manicômio e do técnico na constituição da hegemonia (Slavich, 1989).

A constatação, extraída desse contexto, é que, nem a psiquiatria nem o manicômio, ou ainda, os técnicos, podem ser pensados de forma neutra, enquanto pertencentes a um aparato científico que funciona bem ou mal, dependendo do estado de desenvolvimento científico, ou da qualidade da administração ou dos recursos que thes são disponíveis.

Crimini de pace, ${ }^{83}$ que Basaglia denomina de "obra de corrosão das 'verdades científicas'”, propõe uma leitura crítica do percurso goriziano. Em seu entendimento, a primeira condição de possibilidade para o desenvolvimento da experiência de Gorizia

ঞ Consideraçōes sobre uma experiência comunitária, escrito em 1968, em colaboração com os operadores de Gorizia. In: Amarante (1994c).

ibid., p.103.

в Crimini di pace (Basaclia, Franco \& Basaglia, Franca O., 1982:237-338). Publicado originalmente em 1975. 
refere-se ao questionamento dos técnicos, que deveriam rejeitar, desde então, a delegação de poder implícita nos seus saberes, em conseqüência de uma série de transformações econômicas e sociais que passam a ocorrer na Itália.

Desenvolve-se, assim, uma reflexão sobre os intelectuais e os técnicos do saber prático na organização da cultura e da hegemonia, numa abordagem que inspira-se, fundamentalmente, em Gramsci e Sartre. A discussão se inicia com a definição de intelectuais orgânicos, proposta por Gramsci (1968), como os funcionários e os serviçais do consenso, em que se situa a questão da contribuição dos técnicos da psiquiatria na construção desse mesmo consenso. Funcionários do consenso, ou técnicos do saber prático, na concepção de Sartre, ${ }^{84}$ são os executores materiais das ideologias e dos "crimes da paz", isto é, da violência que se exerce sobre as pessoas com o pretexto de, legal e cientificamente, recuperá-los. São esses mesmos operadores que devem refletir sobre suas funções e papéis, sobretudo sobre suas reais possibilidades de transformação.

Para Franca, um dos aspectos centrais do trabalho em Gorizia é a problemática

da individuação da função política implícita na intervenção técnica que, bem longe de conservar a neutralidade habitualmente atribuída à ciência, contribui teórica e praticamente para a manutenção do sistema sócio-econômico do qual é expressão. (Basaglia, Franca O., 1981:xxxix)

Dessa forma, apresenta-se para Basaglia uma opção que define a importância da experiência de Gorizia no âmbito das transformaçōes no campo social:

Ou aceitamos ser os concessionários do poder e da violência (caso em que toda e qualquer ação de renovação mantida nos limites da norma será aceita entusiasticamente como a solução do problema), ou nos negamos a tal ambigüidade tentando (nos limites do possível, pois estamos bem conscientes de que fazemos parte, nós mesmos, desse poder e dessa violência) enfrentar o problema de modo radical, exigindo que seja englobado em uma discussão de conjunto que não poderia satisfazer-se com soluçōes parciais, mistificadoras. ${ }^{85}$

O processo de negação desenvolvido em Gorizia é, ao mesmo tempo, um processo de renúncia do mandato 'terapêutico' do técnico, de recusa da delegação de controle social exercida pela instituição, e de questionamento do saber psiquiátrico. 
Mas, como se viu, para Basaglia a dimensão negativa é também superação e invenção de novos contratos:

Fizemos nossa escolha, que nos obriga a ficar ancorados ao doente, como resultado de uma realidade que não se pode deixar de questionar. Por isso limitamo-nos a contínuas verificações e superações que, de maneira muito superficial, são interpretadas como signos de ceticismo ou de incoerência relativamente à nossa ação. ${ }^{86}$

E, se essa operação de negaçăo-superação-invenção é um processo dialético, é, por extensão, um processo que traz mais questões que respostas. Para a psiquiatria moderna tal premissa se apresenta como algo absolutamente irresponsável, aventureiro, sem base científica, pois lhe parece incompreensível uma instituição psiquiátrica sem um projeto terapêutico, nos moldes do que se define como ciência. É o que reconhece Basaglia:

Talvez fosse mais simples restringir-nos ao próprio terreno de ação e de estudo, conservando a distância - indispensável à análise científica - entre aquele que questiona e o objeto do questionamento. O trabalho científico, enquanto se mantém no interior dos valores normativos, é sério e digno de respeito desde que se previna e se muna contra o venir da realidade que nega e contradiz. Mas se um trabalho se funda na realidade e em suas contradiçōes, sem pretender construir um modelo que confirme e codifique as próprias hipóteses, traz em si a marca do diletantismo veleidoso relativamente a tudo aquilo que ainda não está incluído na norma, e leva ao paradoxo de uma situação dialética, sempre em movimento. ${ }^{87}$

Para transformar essa realidade, é necessário sair do território exclusivamente psiquiátrico e construir na sociedade as condições para que ela, como espaço real da vida humana, participe da solução. Esta, se algo tem de particularmente psiquiátrica, e se é que existe como algo definitivo, deve ser possibilitada por um conjunto de transformações que digam respeito a todos os homens. A doença não é a condição única, nem a condição objetiva do ser humano que está doente, ao mesmo tempo em que o aspecto em que se encontra o doente é produzido pela sociedade que o rejeita e pela psiquiatria que o gere.

s Ibid., p.132.

s Ibid., p.9-10. 
Por isso, diz Basaglia na apresentação de $A$ Instituição Negada,

o nosso discurso antiinstitucional, antipsiquiátrico (isto é, antiespecialístico), não pode restringir-se ao terreno específico de nosso campo de ação. $O$ questionamento do sistema institucional transcende a esfera psiquiátrica e atinge as estruturas sociais que o sustentam, levando-nos a uma crítica da neutralidade científica - que atua como sustentáculo dos valores dominantes -, para depois tornar-se crítica e ação política. ${ }^{88}$

A ciência tornou o doente um objeto de estudo, da mesma forma que a instituição tornou-o objeto da estrutura manicomial. O que justifica então suas permanências, senão as funções sociais que desempenham? Não foi a ciência que propiciou "a 'invenção' do doente à semelhança dos parâmetros que o definiram?" ${ }^{\prime \prime 9} E$, por que, então, não negar toda essa realidade?

Para Basaglia, mudar a psiquiatria é mudar a instituição e suas práticas; mudar a instituição e suas práticas é mudar o saber psiquiátrico. Embora a ação prático-teórica seja voltada num primeiro momento para o problema do manicômio, o projeto de transformação iniciado por Basaglia não se restringe ao hospital psiquiátrico. O manicômio fornece a condição de possibilidade epistêmica da psiquiatria, o que faz com que este seja um lugar prático e simbólico de eleição para o processo efetivo de desinstitucionalização.

Os passos iniciais da desinstitucionalização consistem, pois, no desconstruir o paradigma problema-solução, no envolver e mobilizar nesse processo os atores sociais envolvidos, inclusive os internos - já não mais sob o critério de 'desalienação' -, o que permite descobrir que esse não é um problema puramente 'tecnocientífico', mas também normativo, social e ético.

E depois?, pergunta-se Basaglia. "Não sabemos qual poderá ser o próximo passo", ao que responde ele próprio: "A realidade não pode ser definida a priori: no momento mesmo em que é definida, desaparece enquanto conceito abstrato"..$^{90}$

Ibid., p.9.

Ibid., p.126.

Idem. 
No entanto, é possível percorrê-la, construindo cada passo de uma certa trilha: "um andarilho vai pela noite/ A passos largos;/ Só curvo vale e longo desdém./ São seus encargos./ A noite é linda./ Mas ele avança e não se detém./ Aonde vai seu caminho ainda?/ Nem sabe bem (...)".91

\section{Uma importante inversão: a doença mental entre parênteses}

A doença mental, objeto construído pela psiquiatria, tem sido a justificativa que sustenta a exclusão daqueles que são considerados enfermos. A realidade manicomial, contudo, vem demonstrar que o que se exercita sobre a doença objetivada é mais um ato de violência que um ato de cura ou libertação. Mas o que é a doença mental? Esse conjunto de trejeitos, excentricidades, idéias absurdas e obscenas que o psiquiatra observa, cataloga, relaciona e interpreta? E, sobretudo, quem é esse homem, doente, autor de todas essas expressões?

Para Basaglia,

esta objetivação do homem em síndromes, operada pela psiquiatria positivista, tem tido conseqüências extremamente irreversíveis no doente que - originariamente objetivado e restrito nos limites da doença - foi confirmado como categoria fora do humano por uma ciência que devia distanciar-se e excluir aquilo que não estava em grau de compreender.

Todavia, se é verdade que uma análise científica - qualquer que seja o problema do qual se ocupa - representa a pesquisa do fundamento de um fenômeno, uma vez que ele esteja isolado das superestruturas e das ideologias das quais é habitualmente velado, desejando-se afrontar cientificamente o problema do doente mental se deverá, a princípio, colocar 'entre parênteses' a doença e o modo no qual foi classificada, para poder considerar o doente no seu desenvolver-se em modalidades humanas que propriamente enquanto tal - devemos procurar avizinhar-nos..$^{92}$

91 Nietzsche (1978:404). Interessante a semelhança com o poema de Antônio Machado: "Andarilho, o caminho é feito de seus passos, nada mais;/ andarilho, não há um caminho, você faz o caminho ao caminhar./ Ao caminhar você faz o caminho/ $\mathrm{E}$ ao olhar para trás, você verá um caminho sem retorno./ Andarilho, não há nenhum caminho,/ apenas trilhas na onda do mar". Apud VARELA (1990:45-60). E ainda, a relação entre a floresta e o andarilho que se perde da trilha, descrita por LEÃo (1991:8): “Estar perdido não é uma realidade da floresta. É apenas uma imposição da funcionalidade".

\$ Un problema di psichiatria istituzionale (dalla vira istituzionale alla vita di comunità) (BASAGLIA, Franco, 1981: 328-339). Escrito em 1966 em colaboração com Franca Basaglia, p.309-310. 
O princípio de colocar a doença mental entre parênteses diz respeito à individuação da pessoa doente, isto é, a um ocupar-se, não da doença mental como conceito psiquiátrico - que tem sido questionado tanto no aspecto mais propriamente científico, quanto na sua função ideológica--, e sim, pelo contrário, a um ocupar-se de tudo aquilo que se construiu em torno da doença. A épochè da doença mental surge da necessidade, precedente a qualquer classificação, de poder voltar as vistas para o doente. ${ }^{93}$ Essa operação epistemológica reporta a uma inversão dialética da questão psiquiátrica, na qual "o doente foi isolado e colocado entre parênteses pela psiquiatria para que se pudesse ocupar de definições abstratas de uma doença, da codificação das formas, da classificação dos sintomas..." ${ }^{\prime 94}$

A inversão está, pois, no princípio de colocar, não o doente entre parênteses, mas a doença mental, isto é, o saber psiquiátrico que sobre ela se produziu. Para Franca, é dessa forma que no trabalho efetivo em Gorizia impõe-se

uma ação prática de desmantelamento das incrustações institucionais que cobriam a doença; era, assim, necessário tentar colocar entre parênteses a doença como definição e codificação dos comportamentos incompreensiveis, para buscar extrair as superestruturas dadas pela vida institucional, para poder individuar quais partes haveriam contribuído para a doença, e quais as instituições, no processo de destruição do doente. (Basaglia, Franca O., 1981:xxii)

O colocar entre parênteses o 'fenômeno' é uma importante demarcação epistemológica. Ainda para Franca, é o 'lugar' do pensamento existencial. É, pois, a partir de uma atitude 'intensamente husserliana' (a noção de épochè provém de Husserl) que Basaglia opera a primeira 'negação'. Esse princípio consiste na idéia de que o 'fenômeno' não existe em si, mas é construído pelo observador, é um constructo da ciência, e só existe enquanto inter-relação com o observador. Se o observador, sujeito do conhecimento, constrói o 'fenômeno', este é parte do primeiro, é parte de sua cultura e de sua subjetividade. Sciacca considera que a redução fenomenológica, ou suspensão, este 'pôr entre parênteses', o fenômeno,

9 A esse respeito, ver Corpo e instituzione, p.439. 
significa dar outra vez à consciência a sua liberdade, isto é, o conhecimento que não existe, só o sentido psicológico ou dialético ou científico da realidade, mas, como fundamento de todos estes sentidos, o sentido ontológico dela. (Sciacca, 1968:260)

Binswanger, de acordo com Basaglia,

havia já pontualizado o perigo de ir de encontro a um método de abordagem científica que 'distanciado-se de nós mesmos, comporta uma concepção teórica, da observação, do exame, do desmembramento do homem real com o objetivo de construir cientificamente uma imagem'. ${ }^{95}$

Ora, se a doença mental é uma construção da psiquiatria, deve-se argüir quanto às condições e operações dessa construção. Em suma, qual o valor real da psicopatologia ao tratar do tema doença mental? Ou, ainda, argüir em que a psicopatologia efetivamente contribui para dizer do sujeito em sua experiência da loucura?

Com o princípio do colocar entre parênteses a doença mental, Basaglia inaugura um procedimento epistemológico quanto ao saber psiquiátrico, que desenvolvese posteriormente de forma mais abrangente sobre o papel e a função das ciências e dos técnicos.

Apenas dessa forma, "a psiquiatria como ciência assumirá uma dimensão humana", isto é, "passará a fronteira entre a ideologia e a ciência", cessará de referir-se a um esquema de funções para ocupar-se do homem real, e se poderá falar de

'um verdadeiro e próprio conhecimento compreensivo que reconduzirá o homem no mundo social'. Então, a antropofenomenologia tornar-se-á, ela própria - quanto à sua dialética interna - base desta nova ciência. Mas uma passagem semelhante (da ideologia à ciência) poderá vir somente em 'condições que nós próprios possamos nos liberar, inscrevendo nos nossos conceitos o resultado irreversível desta passagem'. ${ }^{96}$

A operação 'colocar entre parênteses' é, muitas vezes, entendida como negação da existência da doença, o que em momento algum é cogitado. Significa, tãosomente, que a psiquiatria construiu conceitos de sintomas e doenças sobre fenôme-

क Che cos'è la psichiatria?, p.388.

* L'ideologia del corpo come espressività nevrotica - le nevrose neurasteniche, escrito em 1966 (1981:347). As duas primeiras citaçōes são de Sartre, em Crítica da Razāo Dialética, e a última de Althusser, em Pour Marx. 
nos que, em última instância, lhes são absolutamente incompreensíveis e que, portanto, cumprem papel meramente ideológico. Assim, a necessidade de colocar a doença entre parênteses significa a negação, isto sim, da aceitação da elaboração teórica da psiquiatria em dar conta do fenômeno da loucura e da experiência do sofrimento; significa realizar uma operação prático-teórica de afastar as incrustações, as superestruturas, produzidas tanto no interior da instituição manicomial, em decorrência da condição do estar institucionalizado, quanto no mundo externo, em conseqüência da rotulação social que é fortemente autorizada pelo saber psiquiátrico. Em outras palavras, o colocar entre parênteses 'não significa a negação da doença mental', mas uma recusa à aceitação da positividade do saber psiquiátrico em explicar e compreender a loucura/ sofrimento psíquico.

A doença entre parênteses é, ao mesmo tempo, a denúncia e a ruptura epistemológica que permite a observação do 'duplo' da doença mental, isto é, do que não é próprio da condição de estar doente, mas de ser e estar institucionalizado (e não apenas hospitalizado), que reabre a possibilidade de um outro conhecimento sobre essa mesma condição.

Um homem dos vinhedos falou, em agonia, junto ao ouvido de Marcela. Antes de morrer, revelou a ela o segredo:

- A uva - sussurrou - é feita de vinho.

(...) Se a uva é feita de vinho, talvez a gente seja as palavras que contam o que a gente é. ${ }^{77}$

\section{O duplo da doença mental}

O princípio imperativo prático-teórico de colocar entre parênteses a doença mental permite que seja visualizado um processo que passa a ser denominado de o 'duplo da doença mental'. O duplo é algo que se sobrepōe à doença, que surge como conseqüência do processo de institucionalização, que homogeneiza, objetiva e 'serializa' (no sentido proposto por Sartre) a todos aqueles que entram na instituição. Nesta, é constituído um conjunto de formas de lidar, olhar, sentir o internado, com base naquilo que se supõe ser o louco e sua loucura. Assim, 'por duplo da doença mental' é entendido tudo aquilo 
que se constrói em termos institucionais em torno do internado: é a face institucional da doença mental, construída tomando-se por base a negação da subjetividade do louco, da negação das identidades, a partir da objetivação extrema da pessoa como objeto do saber. São formas institucionais de lidar com o objeto, e não mais com o sujeito, sobre o qual edificam-se uma série de 'pré-conceitos' 'científicos', fundados em noções tais como a de periculosidade, irrecuperabilidade, incompreensibilidade da doença mental.

O processo de desconstrução do conceito de doença mental, na prática, consiste em procurar identificar todo o percurso de montagem do 'duplo' da face institucional da doença, que encobre, junto com o próprio sofrimento, o sujeito, a pessoa. Para Basaglia, enfrentar esse 'duplo', desmontar as incrustações, revelar o sujeito que sob ela se mascara e se coisifica, deve ser o primeiro e o mais fundamental ato terapêutico.

No hospício, todas as pessoas tornam-se iguais, são objetivadas; não impırtam suas histórias, culturas, sofrimentos. Mas essa objetivação é vista posteriormente, pda psiquiatria, como sendo os sinais ulteriores da doença: diferentes são apenas seus sináis e sintomas psicopatológicos. A inércia, a estereotipia, as formas de alheamento ta realidade, assim como tudo aquilo que tem relação com as perdas, a perda de contratualidade, a perda de uma colocação socialmente reconhecida e, enfim, todo o fenômeno de de-socialização que parte da doença passam a ser entendidos como sinais e sintomas do curso de uma doença que tem desenvolvimento natural, de um percurso que é dado pela própria natureza da entidade psicopatológica, e não, nem ao menos parcialmente, das conseqüências diretas da institucionalização.

O doente, assim recluso em um espaço no qual é submetido a um teclado de variadas espécies de violências, passa a incorporar em seu comportamento, por força dessas mesmas violências, tudo aquilo que a instituição deseja que se torne: violento, antissocial, melancólico, enfim, alienado (e é bastante adequado aqui o duplo sentido da palavra alienação). Se o sujeito, portador ou não de um sofrimento mental, é peremptoriamente submetido a tal situação, ao cabo de algum tempo torna-se difícil distinguir o que lhe é próprio, o que é próprio do seu sofrimento, do que lhe é impresso pela condição de institucionalizado.

Mas tais incrustações não ocorrem somente no internado, ou no processo de internação, pois a institucionalização, enquanto produtora de um saber e de uma verdade sobre o louco e a loucura, tem no asilo apenas o seu lugar de exercício, de escola, de testemunha e confirmação do fim inexorável da loucura. O louco manicomializado não é o símbolo da alteridade do louco libertado, é apenas a sua radicalização, seu futuro incontestável. 
A construção que a psiquiatria elabora sobre o louco se reproduz pela sociedade e tende a ser assimilada como verdade inquestionável pelas famílias, pelas escolas, pelas artes, pelas culturas, pelas ruas. A conduta das pessoas para com os loucos passa a ser aquela mesma que a psiquiatria produz e adota. Aos que disso duvidarem, aos que refutarem que loucura é sinônimo de demência, agressividade, insensatez, periculosidade, irresponsabilidade, indecência, imoralidade, basta andar até o manicômio e conferir se não é mesmo assim. Eis porque a idéia do duplo não fica restrita exclusivamente ao institucionalizado no hospital psiquiátrico, mas estende-se ao conjunto das instituições psiquiátricas, psicológicas, psicoterápicas, culturais, sociais, que contribuem para a construção, em torno da pessoa, de uma face que não é aquela dos sujeitos.

Em La malattia e il suo doppio e La maggioranza deviante, ${ }^{98}$ a idéia do 'duplo' é melhor desenvolvida enquanto crítica não apenas à definição de doença mental, mas também ao processo de ideologização pelo qual os problemas são desfigurados e são transformados em outros problemas, de tal forma que se possa dar respostas artificiais, sem alterar a sua verdadeira natureza ou a ordem das coisas. Para tanto, Basaglia passa a tratar da questão das 'minorias' que são discriminadas e, portanto, inscritas em categorias sociopsiquiátricas. Assim é que o negro, o pobre, o doente físico e o imigrante, para ficar em alguns exemplos, são considerados diferentes e diversos, mas inscritos em categorias inferiores. Sobre tais categorias de diferentes e diversos constroem-se conceitos e formas socioculturais de lidar que, em última instância, determinam duplos sobre essas situações de vida, identidades e biografias: ${ }^{99}$

É este 'duplo' que deve ser possivel compreender, e a pesquisa no terreno prático de um dos momentos deste processo sempre em atividade, que é da individuação da passagem da experiência humana a um comportamento comum sempre mais desumano, poderia dar-se o sinal disso que seria o homem em uma realidade onde o 'duplo' conservasse o caráter da contradição, visível através de uma dialética humana. ${ }^{100}$ O primeiro foi escrito em 1970 (1982:126-146) e o segundo em 1971 (1982:155-184), ambos em co-autoria com Franca Basaglia.

A esse respeito é importante o conceito de estigma, extraído de Goffman (1975): "O termo estigma, portanto, será usado em referência a um atributo profundamente depreciativo, mas o que é preciso, na realidade, é uma linguagem de relaçōes e não de atributos. Um atributo que estigmatiza alguém pode confirmar a normalidade de outrem, portanto, ele nāo é, em si mesmo, nem honroso nem desonroso" (Goffman, 1975:13). 
A idéia do 'duplo' torna-se ponto de partida obrigatório, e ponto de partida ao qual deve-se retornar sistematicamente, pois sempre se constituirá novo ponto de partida. $\mathrm{O}$ conceito do 'duplo' não apenas denuncia a função alienante, violenta, iatrogênica da psiquiatria mas, e fundamentalmente, coloca em questão sua função terapêutica.

Nunca, quando é a própria vida que nos foge, se falou tanto em civilização e cultura. E existe um estranho paralelismo entre esse esboroamento generalizado da vida, que está na base da desmoralização atual, e a preocupação com a cultura, que nunca coincidiu com a vida e que é feita para dirigir a vida. ${ }^{101}$

\section{A desinstitucionalização como estratégia para a instituição inventada}

A noção de desinstitucionalização é uma das mais importantes referências, e não apenas no Brasil, do atual projeto de reforma psiquiátrica. É com Basaglia que a mesma deixa de ser entendida em sua versão abolicionista, isto é, como ausência absoluta de mecanismos institucionais de controle e violência para com a loucura, ou como simples desospitalização, tal como originalmente proposta pelos norte-americanos, para integrar-se num contexto maior, que remonta à idéia de desconstrução.

A desinstitucionalização, em Basaglia, é construída fundamentando-se em duas outras noçōes, quais sejam, institucionalização e poder institucionalizante, que são derivadas tendo como bases os conceitos de neurose institucional, de Burton, e de instituição total, de Goffman. São conceitos que, trazendo à luz a profundidade do processo de institucionalização, apontam, conseqüentemente, para a real dimensão desinstitucionalizante. Institutional neurosis abre, para Basaglia, a perspectiva de uma nova dimensão de "vazio emocional" do enfermo, uma vez que este ultrapassa o muro da intemação ${ }^{102}$ e demarca os efeitos da institucionalização sobre o institucionalizado, que se configuram como de caráter mais nocivo que terapêutico. Em outras palavras, a institucionalização passa a ser percebida como novo problema, como algo a impor novos sofrimentos e alienação, e não como solução terapêutica para a enfermidade mental.

\footnotetext{
101 Artaud (1988) apud BASAGlia, Franco \& BASAGliA, Franca O., em La maggioranza deviante (1982:177-178).

102 La distruzione dell'ospedale psichiatrico, p.250.
} 
A influência de Goffman é marcante e remonta aos primeiros anos da fase de Gorizia, tornando-se uma referência constante na grande maioria dos escritos de Basaglia. Já em La distruzione dell'ospedale psichiatrico, texto que marca a abertura do interesse acerca da instituição psiquiátrica, Basaglia afirma:

se poderia dizer, todavia, que toda organização de características. coletivísticas (grandes complexos industriais por exemplo), embora não apresentem o clima institucionalizante dos espaços fechados (manicômios, cárceres, campos de concentração, institutos religiosos, escolas), violam, em certo sentido, o projeto individual. ${ }^{103}$

Também aqui o conceito de 'mortificação do eu', presente já no subtítulo do artigo, que designa um processo de desfiguração, profanação e violação do sujeito institucionalizado, denota a importância de Asyluns para o projeto de desinstitucionalização. Em suma, é em decorrência do saber psiquiátrico construído sobre a loucura, entendida como ausência de projeto, que a psiquiatria permite-se submeter os internos ao processo de mortificação e de 'carreira moral'. ${ }^{104}$

Para Basaglia, a 'institucionalização' é:

o complexo de 'danos' derivados de uma longa permanência coagida no hospital psiquiátrico, quando a instituição se baseia sobre princípios de autoritarismo e coerção. Tais princípios, donde surgem as regras sob as quais o doente deve submeter-se incondicionalmente, são expressão e determinam nele uma progressiva perda de interesse que, através de um processo de regressão e de restrição do Eu, o induz a um vazio emocional. ${ }^{105}$

Como 'poder institucionalizante' é entendido o conjunto de forças, mecanismos e aparatos institucionais que ocorrem quando

Ibid., p.250-251.

"O novato chega ao estabelecimento com uma concepção de si mesmo que se tornou possível por algumas disposiçōes sociais estáveis no seu mundo doméstico. Ao entrar, é imediatamente despido do apoio dado por tais disposições. Na linguagem exata de algumas de nossas mais antigas instituiçōes totais, começa uma série de rebaixamentos, degradaçōes, humilhaçōes e profanaçōes do seu eu. O seu eu é sistematicamente, embora muitas vezes não intencionalmente, mortificado. Começa a passar por algumas mudanças em sua carreira moral, uma carreira composta pelas progressivas mudanças que ocorrem nas crenças que têm a seu respeito e a respeito dos outros que são significativos para ele" (Goffman, 1974:24).

La 'comunità terapeutica', p.259. 
o doente, fechado no espaço augusto da sua individualidade perdida, oprimido pelos limites impostos pela doença, é forçado, pelo poder institucionalizante da reclusão, a objetivar-se nas regras próprias que o determinam, em um processo de redução e de restrição de si que, originariamente sobreposto à doença, não é sempre reversível. ${ }^{106}$

É aqui que podemos encontrar as bases mais primitivas do projeto que se delineia em torno da noção de desinstitucionalização, a qual será uma das linhas condutoras mais fundamentais do projeto basagliano.

Tais conceitos são o ponto de partida do projeto de desmontagem prático-teórica do manicômio de Gorizia, que se volta para dois principais aspectos, e que diz respeito à luta contra a 'institucionalização do ambiente externo' e à luta contra a 'institucionalização completa do corpo hospitalar' (institucionalização do médico, dos enfermeiros, do doente). Com a luta contra a institucionalização do ambiente externo inicia-se o processo de distanciamento de Jones e Tosquelles. Em primeiro lugar, porque, e a partir de então, aspira-se a uma transformação no âmbito da sociedade, na forma com que esta lida com a loucura, e não apenas e meramente a uma luta para a transformação interna do manicômio. Em segundo lugar, porque se entende que as reformas eminentemente asilares, como é o caso da comunidade terapêutica e da psicoterapia institucional, não problematizam sua função institucional precípua, na medida em que não problematizam a relação dentro-fora. Isto é, impõe-se a necessidade de

inventar novas estratégias que (...) possam fluidificar as relações dentrofora da instituição, abolir o automatismo e a violência da internação forçada, criar novos níveis de troca e de relações, não tanto em condições de humanizar a instituição, mas de suplantá-la e substituí-la por uma organização alternativa. ${ }^{107}$

A comunidade terapêutica é criticada por pretender tornar-se uma técnica com fim em si própria", que nada mais faz do que encobrir,

por intermédio de uma nova ideologia, as contradições sociais que tinha tentado tornar explícitas. Neste caso as velhas instituições manicomiais, definiveis como instituições da violência, podem facilmente traduzir-se em

\footnotetext{
106 La distruzione dell'ospedale psichiatrico, p.250.

107 Vocação terapêutica e luta de classes, p.38.
} 
instituiçōes da tolerância nas quais os termos das relações, implícitos na realidade manicomial, sejam transformados radicalmente sem que nelas seja destruída a relação mundo interno e externo. ${ }^{108}$

Em outras palavras, a transformação da atitude, de violência para tolerância, tal como operada na comunidade terapêutica, não significa uma transformação dialética do processo dentro-fora, do processo de inclusão-exclusão social do louco, isto é, de inserção da loucura no espaço social. A exclusão, embora sem as características violentas da psiquiatria asilar, continua a existir sob a égide da tolerância e da complacência.

A luta contra a institucionalização do corpo hospitalar reflete as influências de Gramsci e Sartre para a reflexão sobre o papel do técnico, da ciência e das instituições. As reflexões de Gramsci sobre os intelectuais e a organização da cultura contribuem para a organização da intervenção prática sobre o papel dos psiquiatras, dos técnicos da saúde e da psiquiatria como ideologia. Tomando-se por base Sartre, são desenvolvidas as discussões sobre a ideologia e a razão dialética, mas, sobretudo, sobre a função dos técnicos e dos intelectuais do saber prático. É nesse contexto que surge a discussão, mantida até os dias atuais no trabalho desenvolvido em Trieste, do mandato social da psiquiatria, isto é, da função que lhe é outorgada pela sociedade de administrar as populações desviantes.

Mas a luta contra a institucionalização interna é também uma ação prática contra a 'carreira moral' produzida pela 'institucionalização total': "para o homem imóvel, sem um futuro, um objetivo, um projeto, uma espera, uma esperança em torno da qual se voltar (...) o melhor é a reconquista da própria liberdade..."109

A desinstitucionalização, portanto, deve se realizar em dois níveis simultâneos, um teórico e outro político. Tais níveis estão referidos às duas faces da realidade da doença e do estar-doente: a de uma problemática psicopatológica (dialética e não ideológica) e a de uma problemática de exclusão, de estigmatização social, das quais nasce a hipótese de ação prático-teórica, que passa a orientar os últimos momentos do trabalho em Gorizia, assim como o início do trabalho em Trieste, cuja base é a 'invenção' de novas estruturas assistenciais e terapêuticas.

Com um perfil dessa natureza, a desinstitucionalização torna-se um processo que deve ser levado a cabo não apenas no hospital psiquiátrico - e também porque a instituição psiquiátrica não é entendida tão-somente como o manicômio -, mas no 
conjunto de saberes e práticas operadas sob o título de psiquiatria. Um exemplo desse processo de desinstitucionalização é a desconstrução dos conceitos de desvio, normalidade-anormalidade, desajustamento e personalidade psicopática, que contêm não apenas uma análise epistemológica, mas uma crítica ao lidar social e político com os mesmos.

Algumas dessas questões são permanentemente retomadas em sucessivos trabalhos, os quais contribuem para a trajetória da ação prática na transformação das instituições psiquiátricas de Trieste. Dentre tais questões, destacam-se:

- a análise crítica dos conceitos e da intervenção tecnocientífica sobre os desviantes, psicopatas, desajustados e as minorias;

- a análise crítica do 'chegar a um consenso', técnica utilizada para resolver os conflitos sociais muito adotada nas experiências de comunidade terapêutica, considerada pela 'nova psiquiatria' como o principal recurso democrático para a gestão institucional. No entendimento de Basaglia, contrariamente, não é mais que a técnica para obter a subordinação e o consentimento dos internos ao poder institucional; ${ }^{110}$

- a análise crítica da transposição de modelos constituídos em determinado contexto histórico, político e cultural que, transferidos para outro contexto que não requer as mesmas necessidades e estratégias, termina por impor novas ideologias de controle e normatividade. Essa transposição, denominada "ideologia de recâmbio ou de substituição", ${ }^{111}$ ocorre quando as novas técnicas e saberes produzidos em uma realidade diversa são acriticamente transportados para outra realidade e tomados como verdade;

- a análise crítica da função das multi e interdisciplinaridades como tecnologias capilares de controle. São questões retomadas e aprofundadas mais especificamente nos prefácios de Ideologia e pratica della psichiatria sociale, de Maxwell Jones (1982:105-125), ${ }^{112}$ I/ comportamento in pubblico, de Goffman (1982:147-154), ${ }^{113}$ e Lo psicanalismo, de Castel (1882:349-335), ${ }^{114}$ e nos artigos La malattia e il suo doppio (proposte critiche sul

Lettera da New York: il malato artificiale, escrito em 1969 (1982:103).

Esse conceito foi elaborado em discussōes com Gianni Scalia. A esse respeito, ver La maggioranza deviante, p.157.

112 Escrito em 1970, em colaboraçăo com Franca Basaglia.

113 Escrito em 1971, em colaboração com Franca Basaglia.

Escrito em 1978, em colaboração com Franca Basaglia.
} 
problema delle devianze) (1982:126-146), ${ }^{115}$ Lettera da New York - il malato artificiale (1982:96-104), ${ }^{116}$ La maggioranza deviante (1982:155-184), ${ }^{117}$ Riabilitazione e controllo sociale (1982:199-208), ${ }^{118}$ e em Follia/delirio (1982:411-444). ${ }^{119}$

Em La maggioranza deviante, a noção de ideologia de recâmbio insere a questão da produção social de comportamentos desviantes nos países de capitalismo avançado, com a conseqüente exportação para outros países com situação diversa. Ideologia de recâmbio pode ser assim definida:

No âmbito das ciências humanas normalmente enfrentam-se problemas teórico-científicos que não nascem diretamente da realidade em que se vive, mas que são importados como problemas típicos de outras culturas (de níveis diversificados de desenvolvimento), transferidos para um terreno onde se individualizam os sinais da sua presença em condição de um reconhecimento crítico preciso. ${ }^{120}$

Ainda nesse ensaio, Basaglia disseca as várias formas de produção do desvio, apoiando-se em Goffman, Parsons, Artaud, Lewis, Cooper, Fromm, utilizando exemplos práticos de várias minorias em muitas realidades nacionais, tecendo uma profunda crítica aos sistemas terapêuticos voltados para o 'tratamento' do desvio. Este é entendido pela cultura psiquiátrica como anormalidade originária, estrutural, da qual se funda a 'ideologia da diversidade' como a intensificação raḍical das diferenças entre os opostos, entre saúde e doença, entre norma e desvio, ideologia esta que sanciona a inferioridade do outro por meio da afirmação da própria superioridade. O capitalismo avançado produz uma série de novas normas e, conseqüentemente, de novos desvios que, patologizados pelos saberes científicos, constituem novo tipo de 'duplo'.

Enfim, a psiquiatria coloca o seu saber à disposição para dar consistência e legitimar novas categorias de patologias, de desvios e de condutas anormais. Esse processo, conforme demonstra Basaglia no decorrer de sua análise, tem muito mais a ver com a função social e ideológica da psiquiatria que com uma possível verdade dos fenômenos. Nas sociedades complexas isso tem ocorrido de tal forma que, afirma Basaglia, dentro dessa mesma ótica a maioria da sociedade seria desviante.

Escrito em 1970, em colaboraçăo com Franca Basaglia.

Escrito em 1969.

Escrito em 1971, em colaboraçâo com Franca Basaglia.

Escrito em 1971.

Escrito em 1979, em colaboração com Franca Basaglia.

La maggioranza deviante, p.155.
} 
Um outro aspecto da desinstitucionalização está na crítica à idéia de uma resposta exclusivamente técnica para o tratamento dos problemas mentais, ou melhor, a crítica à idéia, por si só ideológica, de que o 'problema mental' seja exclusivamente psiquiátrico. Nesse sentido há uma absoluta ruptura, não apenas para com a psiquiatria, mas para com a psicanálise. É nessa linha, de recusa da 'solução técnica', que Basaglia desenvolve reflexões sobre a comunidade terapêutica, a psicoterapia institucional, a psiquiatria preventiva e a psicanálise.

Em Le istituzioni della violenza e le istituzioni della tolleranza, ${ }^{121}$ com base na constatação do crescente prestígio das experiências psiquiátricas ditas não-asilares, Basaglia argúi sobre o porquê da necessidade de a instituição psiquiátrica se modernizar no sentido da liberalização. Em outras palavras, por que e como as instituiçōes da violência transmutam-se em instituições de tolerância? Se a comunidade terapêutica, por exemplo, nasce de uma tentativa de rejeição da psiquiatria tradicional enquanto realidade institucional, isto é, enquanto realidade manicomial, torna-se, por assim dizer, um instrumento de explicitação das contradições entre lugar de elaboração teórica e terreno de trabalho prático. Contudo, a partir do que se percebe de seu desenvolvimento, a comunidade terapêutica passa a ser proposta como novo modelo teórico de uma nova realidade institucional, em que a violência do antigo manicômio é substituída pela atitude da tolerância. Vale dizer que, como projeto de um novo modelo teórico, a comunidade terapêutica pretende se tornar uma 'técnica com fim em si própria', que nada mais faz do que encobrir,

por intermédio de uma nova ideologia, as contradições sociais que tinha tentado tornar explícitas. Neste caso, as velhas instituiçōes manicomiais, definiveis como instituições da violência, podem facilmente traduzir-se em instituições da tolerância nas quais os termos das relações, implícitos na realidade manicomial, sejam transformados radicalmente sem que nelas seja destruída a relação mundo interno e externo. ${ }^{122}$

Dito de outro modo, a transformação da atitude, de violência para tolerância, tal como operada pela 'nova psiquiatria', não significa transformação dialética do processo de inclusão/exclusão social do louco, da inserção da loucura no espaço social. A exclusão, embora sem as características violentas da psiquiatria asilar, continua a existir sob a égide da tolerância e da complacência. A loucura e o sofrimento psíquico, para Basaglia, 
não são condições a serem nem violentadas, nem simplesmente toleradas; precisam, ao contrário, serem em parte aceitas pela sociedade, e em parte verdadeiramente tratadas enquanto tal.

Mas eis que surge um paradoxo. Para a psiquiatria, a doença mental é determinada ainda, e predominantemente, pelo conceito de periculosidade que justifica, para além do 'isolamento' terapêutico de Pinel, a natureza violenta, coercitiva e destrutiva da instituição asilar. Embora não se saiba praticamente nada sobre a gênese da doença mental, seja no sentido da psiquiatria, seja no da sociologia, a passagem da instituição da violência para a instituição da tolerância representa uma contradição: a periculosidade e as demais características da natureza perversa da doença mental, que sobre ela autorizam a violência, continuam sendo mantidas no esquema psiquiátrico; tais características não estão em discussão. Deve-se perguntar: como tais características são suportadas em uma instituição liberalizada? Ou é absolutamente ideológica a premissa de tais características?

Por tal paradoxo a pretensa neutralidade da ciência psiquiátrica é desmascarada, no terreno prático, por essas novas instituições psiquiátricas, que tornam flagrante a ideologia científica que encobre a realidade manicomial. Evidenciam-se, assim, as contradições entre o plano da elaboração teórica e o da ação prática sobre o objeto da sua análise "vale dizer, a contradição entre a psiquiatria enquanto ciência abstrata e a psiquiatria enquanto ciência aplicada". ${ }^{123}$

A 'nova psiquiatria', como instituição da tolerância, torna-se apenas um novo momento de uma mesma psiquiatria, que vislumbra nova solução técnica específica para o problema da enfermidade mental. Se a violência é rechaçada, e em seu lugar é adotada a tolerância, tal substituição não é suficiente para resolver o problema da enfermidade mental; talvez seja mesmo, e simplesmente, apenas uma solução social e ideológica. Isso, porque:

violência e tolerância são ainda as duas faces do mesmo mecanismo repressivo e não o momento dialético de uma situação dinâmica (...) Violência e tolerância são os dois pólos sobre os quais o nosso sistema se funda, e um assume significado no ser o oposto a-dialético do outro. ${ }^{124}$

Portanto, se a relação entre loucura e exclusão não é dialetizada, a tolerância torna-se mera atualização do mecanismo de exclusão na sociedade moderna.

123 Ibid., p.81.

124 Ibid., p.84. 
A originalidade antiinstitucionalista da comunidade terapêutica, isto é, a rejeição da violência e a humanização dos espaços terapêuticos, é evanescente no momento em que esta faz da sua terapeuticidade um procedimento de "ortopedia social". ${ }^{125}$

Para Basaglia, a manutenção, na comunidade terapêutica e nas demais 'novas psiquiatrias', dos princípios básicos do velho alienismo, é resultado da ausência ou da perda de uma crítica sistemática quanto à mistificação ou à neutralidade da ciência e quanto ao papel e à função social do técnico. A possibilidade concreta de transformação continua sendo, portanto, o princípio de "problematizar e dialetizar a doença" enquanto entendida como "negatividade sem projeto". ${ }^{126}$

Em 1969, Basaglia é convidado, como professor-visitante, de um Community Mental Health Center e do Maimonides Hospital do Brooklin, quando conhece de perto o Programa Kennedy de psiquiatria comunitária. Defronta-se, assim, com nova oportunidade de perceber que as transformações em psiquiatria não podem ser objeto exclusivo de princípios técnicos, da mesma forma que não podem ser exclusivas de um determinado campo de saber e intervenção social.

Em Lettera da New York, Basaglia constata a ambigüidade desse sistema:

Aqui - sob uma mesma lei que as informa - atuam contemporaneamente as instituições da violência, com o seu significado explicitamente excludente, discriminante e destrutivo, e as instituições da tolerância que, por intermédio de um novo conceito da psiquiatria social e comunitária e a interdisciplinaridade, procuram resolver tecnicamente os conflitos sociais. ${ }^{127}$

Mais adiante, observa que: "a técnica comunitária, embora elaborada como resposta institucional à realidade manicomial, vem assumida como nova técnica psiquiátrica em sentido específico". ${ }^{128}$

Dessa forma, constata que essas novas instituições não existem para tratar as pessoas, mas, paradoxalmente, por meio da prevenção, para produzir uma nova categoria de doentes (os emotional patients), daí o sugestivo título 'o doente artificial', embora não se pudesse dizer (eis porque se tem colocado a doença entre parênteses) que os doentes descritos pela psiquiatria fossem verdadeiramente 'naturais'. O que se

Ibid., p.82-83. A idéia das "ciências humanas ortopédicas" provém do documento dos estudantes da Sorbone durante o movimento pela reforma da Universidade. Ibid., p.85. Observa-se, aqui, uma analogia com Foucault em História da Loucura: "loucura: ausência de obra". 
observa é uma atuação da psiquiatria no sentido de englobar no campo da medicina mental, com maior eficácia e eficiência que o higienismo moral, um conjunto de comportamentos socialmente acusados. Quanto a isso, a prevenção serve para dilatar o campo da 'doença', tanto quanto não serve para curá-la.

Esse alargamento do campo da doença evidencia uma função de controle dos distúrbios sociais por parte das instituições. A 'nova psiquiatria' funda, assim, o que Basaglia denomina de "capilaridade multidisciplinar", que consiste na criação de uma rede tal de controle técnico-social nos países de alto nível tecnológico, que é muito mais penetrante e sutil do que o que ocorre com a psiquiatria tradicional, ou mesmo com as psiquiatrias reformadas, que tornam a barreira entre norma e desvio sempre mais frágil e acusatória. Essa 'nova psiquiatria' tem um endereço social, na qual pesa a competência do controle técnico sobre as questões sociais, configurando-se então na "instituição tolerante, que é a outra face da instituição da violência, conforme proposto anteriormente".

Assim, se por um lado está a crítica à dominação exclusiva do saber psiquiátrico sobre a enfermidade mental, por outro está a crítica à multi e à interdisciplinaridade constituídas enquanto 'nova psiquiatria', isto é, enquanto um conjunto de saberes institucionais que organiza 'os problemas mentais' e sociais em múltiplos e diversos critérios médicos, sociológicos, antropológicos, disciplinares, jurídicos e normativos. A interdisciplinaridade, que viria compor um quadro mais completo de saberes em torno de um objeto de conhecimento, termina por construir novos objetos que, em última instância, servem para criar novos significados para o desvio e para a atitude desviante.

Por essa e outras razões, o procedimento de colocar a doença mental entre parênteses não diz respeito apenas ao trabalho no interior do manicômio. É um processo a um só tempo provisório e permanente. Provisório no sentido de que deve ser realizado com o objetivo de possibilitar emergir o sujeito, seus desejos e sentimentos, obscurecidos pelo conceito de doença mental, e permanente enquanto princípio prático-teórico, que coloca em discussão o saber psiquiátrico em todas as suas dimensões; o colocar entre parênteses é o a priori da desinstitucionalização.

Ao romper com a psiquiatria, faz-se importante escolha:

ficar ancorados ao doente, como resultado de uma realidade que não se pode deixar de questionar. Por isso limitamo-nos a contínuas verificações e superações que, de maneira muito superficial, são interpretadas como signos de ceticismo ou de incoerência relativamente à nossa ação. ${ }^{129}$ 
Desse modo, a pergunta 'o que é a psiquiatria?' pode ser respondida da seguinte forma:

(...) qualquer vocação terapêutica, seja na ênfase colocada na instituição, seja no investimento do social e do território, condena a psiquiatria à sua presunção original: aquela de querer, todavia sem jamais conseguir, expelir, da sua ordem depurada, a carga de miséria e de pobreza que Ihe é constantemente destinada. Esta carga não representa a sua herança ruim, o seu anacronismo, mas é a sua contradição e sua condenação, o seu objeto social. ${ }^{130}$

Com uma natureza dessa ordem, a instituição psiquiátrica, apesar de submetida a um processo de negação/superação, estará sendo sempre reinstitucionalizada. Basaglia entende não ser possível uma real desinstitucionalização, que implicaria visão de uma sociedade sem normas e sem instituições, na qual o poder ou inexistisse ou não teria a capacidade de capturar as diferenças, desvios e contradições.

Está-se, pois, diante de um problema insolúvel. Por um lado, está-se exercitando ou atualizando a velha psiquiatria: toda e qualquer iniciativa pode estar inscrita no mesmo mandato social, de controle, disciplina e segregação. Por outro, não se cogita abandonar os enfermos à própria sorte - já que muitos entendem a desinstitucionalização como desassistência ou como extinção das instituiçōes psiquiátricas.

O reconhecimento desse paradoxo, no entanto, constitui importante tomada de consciência:

(...) uma vez acionado o processo de transformação institucional, damonos conta de quanto é contraditória a existência de uma instituição que nega a própria institucionalidade no seio de nosso sistema social, e cuja dinâmica tende a absorver qualquer movimento que poderia alterar o equilíbrio geral. (...) nossa situação não tem outra saída senão continuar sendo contraditória: 'a instituição é concomitantemente negada e gerida; a doença é simultaneamente posta entre parênteses e curada; a ação terapêutica é ao mesmo tempo refutada e executada'. ${ }^{131}$

Eis porque, para Basaglia, o aspecto terapêutico do trabalho está em "viver dialeticamente as contradições do real". ${ }^{132}$ Mas o que isto significa? Por um lado, a recusa sistemática a uma solução técnica para o 'problema mental' enquanto doença,

\footnotetext{
10 Vocação terapêutica e luta de classes, p.37-38.

131 A instituição negada, p.315-316.

132 L'istituzione negata, p.491.
} 
ao mesmo tempo em que procura se aproximar da experiência concreta do doente, da sua experiência de sofrimento com e em relação à realidade, em uma busca, também sistemática, de invenção de novos tipos de pesquisa e novas estruturas terapêuticas.

Em Potere ed istituzionalizzazione, ${ }^{133}$ é melhor desenvolvida a estratégia de encontrar um novo tipo de relação - de cunho contratual - entre internos, técnicos e sociedade, no qual a função da psiquiatria e a situação dos enfermos sejam questões de responsabilidade comum, e não apenas de uma ciência abstrata e suas instituições de violência e tolerância concretas.

Assim, 'inventar' um novo modo de organizar aquilo que, paradoxalmente, não pode ser organizado, tem como princípio a idéia de que é preciso buscar formas de tratamento que não devam, necessariamente, institucionalizar-se em regras e ordens codificadas. Esse é um desafio extremamente difícil, cujo pressuposto é o rompimento com o modelo teórico da psiquiatria clássica. Dito de outra maneira, diante da necessidade de organização de uma psiquiatria que não tenha o mesmo projeto de até então e, mais complexo ainda, diante da impossibilidade de concretizar essa organização, deve-se assumir a estratégia de formular um esboço de sistema de referimento que deve ser sistematicamente destruído e transcendido para, assim, tornar-se possível construir/desconstruindo um novo tipo de relação entre doentes, técnicos e sociedade. ${ }^{134}$

Dessa forma é construída a idéia de uma relação baseada no contrato, que a psiquiatria dizia ser impossível estabelecer com o enfermo, mas que a prática desinstitucionalizante de Gorizia vem demonstrar a possibilidade. A relação de contrato implica a possibilidade de "inventar novas estratégias de mediação", ${ }^{135}$ que vão de estratégias médicas ou psicológicas a estratégias culturais, sociais e políticas. Para tal propósito é preciso, no agir-prático, superar a ambigüidade da psiquiatria entre a delegação da terapia e a da ordem pública, que continuam a existir nas novas psiquiatrias, $\mathrm{e}$ que operam a passagem de instituições da violência para instituições da tolerância.

\footnotetext{
133 Escrito em 1965, em colaboração com BASAGLIA, Franca O. (1981:283-293).

134 Un problema di psichiatria istituzionale, p.328.

135 Il circuito del controllo: dal manicomio al decentramento psichiatrico, escrito em 1977, em colaboração com os operadores de Trieste (BASAGLIA, Franco \& GianichedDA, 1982:405).
} 
A desinstitucionalização torna-se, portanto, um processo, a um só tempo, de desconstrução dos saberes e práticas psiquiátricas - expresso sobretudo nos princípios do colocar entre parênteses a doença mental, o que permite a identificação e a desmontagem do duplo da doença mental, e no trabalho com o sujeito concreto, encortinado pelo conceito da doença-, a de invenção prático-teórica de novas formas de lidar, não mais com a doença, mas com o sujeito doente.

\section{A cidade: $o$ reencontro com a loucura}

II Circuito del Controllo, uma das últimas contribuiçōes de Basaglia, apresenta algumas análises dos resultados que começam a ser colhidos após muitos anos de prática desinstitucionalizante, e algumas perspectivas quanto aos próximos passos:

No que diz respeito à experiência de Trieste, as dificuldades em aprender, no interior do processo de transformações, os novos conhecimentos que andavam emergindo e, enfim, a dificuldade em comunicar o significado da nossa prática foram, na realidade, também um produto desta mesma prática (...). Por estas razões, somente 'depois', nos seus efeitos de retorno, nas mutações produzidas, era possível compreender (...) o significado de quanto estava acontecendo. Por isto, somente 'depois' era possivel entrever o passo sucessivo, a partir de quanto se tinha modificado, ou restava a ser atacado de resistências e lógicas institucionais. Por isto era difícil então 'compreender' e 'fazer-se compreender'. (...) Por estas razōes, hoje, que o projeto político inicial se coloca como realidade concreta, resta muito mais a memória dos significados que dos fatos. É impossível contar as coisas que aconteceram, já que hoje a história de Trieste é sempre menos uma história de uma instituição e sempre mais a história de muitas vidas (..). Por estas razōes, se devêssemos fazer uma história do trabalho destes anos, não poderíamos fechá-la em um modelo abstrato de técnicas de transformaçāo, mas deveríamos mais que tudo reconstruir a história das transformações dos diferentes processos reais, dos diferentes percursos internos, através dos quais foram transformados, com o espaço institucional que vinha sendo transformado, todos aqueles que gravitavam na área das instituições. ${ }^{136}$ 
A instituição psiquiátrica, como as demais instituiçōes, funcionam bem, na medida em que são capazes de dar respostas rápidas, funcionais e objetivas aos problemas que se lhes apresentam. É essa racionalidade que está sendo negada e superada por uma idéia do 'depois', do a posteriori, isto é, de um futuro que não está dado, mas que está sendo construído por experimentações prático-teóricas no cotidiano da instituição. O 'depois', tal como entendido aqui, implica recusa a uma resposta definitiva, pois há sempre uma realidade que está além do que se sabe e se conhece. Significa, ainda, a possibilidade de invenção de novas realidades e instituições. Por tal motivo, Basaglia afirma: "tratamos, assim, de não encapsular contradições com respostas pré-constituídas, mas de fazer agir, expandir e generalizar, aprofundando todos os significados. Este foi o sentido da destruição do manicômio (...)". ${ }^{137}$

Desde os primeiros passos acreditava-se que a simples "abertura do hospital psiquiátrico" não bastava para "abater a espessura dos muros". Era preciso "inventar novas estratégias...", num a posteriori onde estivesse dialetizada a relação dentro-foranão apenas dentro-fora do asilo, mas do saber psiquiátrico.

É esse o propósito do processo de desinstitucionalização levado a cabo em Trieste. Os internos vão recebendo alta do hospital psiquiátrico e, quando não têm estrutura familiar de apoio, tornam-se ou 'hóspedes' - no sentido de que passam a habitar em espaços do ex-hospital, não mais como internos -, ou passam a habitar em casas e apartamentos no meio da cidade.

À medida que o manicômio vai sendo desativado, vão também sendo construídas novas estruturas assistenciais, como os centros de saúde mental territoriais, nos quais todas as funções básicas de um serviço assistencial psiquiátrico podem ser cumpridas, até mesmo a internação em período de crise. Surgem as cooperativas de trabalho que, abrindo um precedente até então inexistente na história, criam possibilidades de 'trabalho real' para os pacientes, que rompe com a idéia do 'trabalho terapêutico', tal como proposto pela ergoterapia. ${ }^{138}$

\footnotetext{
137 Ibid, p.402.

138 Vários internos que faziam a limpeza do hospital se organizam em uma cooperativa e passam a negociar a sua contratação para cumprir tal tarefa. A administração municipal rejeita a proposta, os membros da cooperativa entram em greve e a administração é obrigada a reconhecer que não tinha mais pessoal próprio para a limpeza; assim, a cooperativa é contratada. Muitas outras cooperativas vão sendo constituídas posteriormente, chegando a cobrir cerca de 30 áreas de serviços e/ ou produção, o que leva o Estado a promulgar legislação específica para o que passa a ser denominado de cooperativas sociais, e depois, em 1991, de empresas sociais, configurando nova possibilidade no campo do trabalho das instituiçōes sociais. Para maior conhecimento sobre as cooperativas e sobre a noção de empresas sociais, ver De Leonardis, MaURı \& Rotelu (1994).
} 
O espaço do ex-hospital psiquiátrico, o mesmo espaço que fora destinado à exclusão dos doentes mentais, é mantido com o objetivo de abrigar essas iniciativas. O espaço da objetivação torna-se espaço de produção de novas subjetividades, de sociabilidade, de produção de novos sujeitos de direito e de vida.

O propósito de Basaglia, ao colocar a doença mental entre parênteses, era o de permitir que a pessoa que sofria pudesse florescer por trás do manto da institucionalização. Era preciso abandonar, ao menos estrategicamente, a preocupação com a doença para fazer emergir o âmago da pessoa que padecia da doença e do processo de institucionalização. Era necessário dar-lhe as condições para subjetivação, para a expressão de seus desejos, seus projetos, sua história. Dell'Acqua (1978), em um dos mais belos exemplos da história do processo triestino - como previa Basaglia -, não faz uma história de leis, normas, atos jurídicos, mas a história de muitas vidas, de muitas biografias que estavam achatadas na instituiçăo asilar, e que passam a tornar-se pessoas após o trabalho de desinstitucionalização. Pessoas diferentes, diversas em suas possibilidades, mas efetivamente pessoas.

A transformação operada por Franco Basaglia abre um campo de relacionamento, com a loucura, diverso daquele gerido pela psiquiatria moderna, que, no manicômio ou fora dele, objetivava o sujeito e propunha uma gestão absoluta de sua vida mediante relação de tutela. Para Basaglia, o louco, expropriado de seus direitos (inclusive o direito a um real tratamento), de sua família e do convívio com a sociedade (estas as palavras de ordem do 'isolamento' de Pinel), deve ter na cidade o espaço real de sua reabilitação, ou melhor, de sua habilitação social, ou, melhor ainda, os "processos de validação social dos sujeitos". ${ }^{139}$ Quando se discutia sobre as melhores formas e lugares para a reabilitação do enfermo mental, Basaglia dizia: "são os espaços da cidade". ${ }^{140}$

... tudo bem arejado, com o ar azul dessa linda enseada de Botafogo que nos consola em sua imarcescível beleza, quando a olhamos levemente enrugada pelo terreal, através das grades do manicômio, quando amanhecemos lembrando que não sabemos sonhar mais... ${ }^{141}$

\footnotetext{
19 Vocaçāo terapêutica e luta de classes, p.43.

tง II circuito del controllo, p.401.

141 LiMA BarReto (1993:27).
} 


\section{O dispositivo da desinstitucionalização}

Como antecipado na Apresentação, pretende-se refletir sobre as contribuições de Basaglia à luz da recente produção sobre a concepção epistemológica da complexidade, tomado-se como base a suposiçāo de que a ciência possa ser pensada como processo construtivista. Tais questōes, tanto pela sua natureza quanto pelas referências culturais que as orientam, apresentam-se como pedestal para as mesmas questões que vêm contribuindo para esse campo da filosofia das ciências que se conhece como complexidade e construtivismo. Uma delas é a reflexão sobre a própria ciência, que, com Basaglia, é desenvolvida em termos da natureza do saber psiquiátrico: seja em uma reflexão interna - isto é, no contexto da estrutura mesma deste saber, como coerência quanto à produção e construção dos conceitos -, seja como crítica externa, elaborada com base nos estudos humanísticos.

Ao levantar tais questões, decorrentes da recomplexificação dos saberes sobre a loucura, as contribuições surgidas a partir de Basaglia podem trazer importantes aspectos para o 'desafio da complexidade', tendo em vista que comportam inovações de método e de mérito, relevantes no contexto da teoria da ciência e do conhecimento (De Leonardis, 1987).

Um desses aspectos pode ser entendido no contexto do "primeiro uso da complexidade", tal como apresentado por Stengers (1989:171-172), ou seja, no desafio de resgatar a singularidade da operação que o conceito oculta, no momento em que em uma situação prática, em um novo encontro empírico impõe-se novo questionamento do conceito e atualiza uma dimensão de interrogação prática. É um encontro empírico dessa natureza que ocorre quando Basaglia se depara com a prática real da psiquiatria no Hospital de Gorizia, e passa a refletir sobre esse conhecimento na perspectiva do saber-fazer que, em última instância, é o fiel da balança dos saberes. Sob essa ótica, a psiquiatria, falida nas suas pretensões terapêuticas e libertadoras, reporta imediatamente à questão do poder. Para Basaglia, esse encontro deixa claro a necessidade de renunciar ao mandato da custódia e da tutela, que se escondem sob o manto da terapia.

Fundamentando-se na constatação da origem de classe operária e indigente da grande maioria dos internos de Gorizia, Basaglia coloca em discussão alguns dos aspectos que vão marcar sua obra prático-teórica: a relação entre a psiquiatria e a justiça, a função social e política dos técnicos e a pretensa neutralidade da ciência. Mas Basaglia nãe se contenta em 'criticar' a psiquiatria; quer encontrar uma forma de realizar uma 
outra psiquiatria que atenda às demandas das pessoas que sofrem de problemas dessa ordem, sem cair na tentação de encontrar a verdadeira explicação ou o tratamento definitivo das enfermidades mentais.

Nesse contato direto com um espaço manicomial, Basaglia pode perceber a realidade prático-discursiva da psiquiatria, e negá-la como ciência. Aqui surgem o princípio do colocar entre parênteses a doença mental e a noção do duplo, como formas práticas e epistemológicas de questionar o saber psiquiátrico e de abrir novas perspectivas para o trabalho no interior da instituição. Tais iniciativas não se apresentam com o intuito de encontrar novas verdades, mas, ao contrário, fundam-se na realidade e em suas contradições, "sem pretender construir um modelo que confirme e codifique as próprias hipóteses". ${ }^{142}$ Não se pretende encontrar novas explicações, a exemplo do que ocorre com a psiquiatria e com as ciências modernas, que produzem suas próprias testemunhas fidedignas (ibid., p.147). O louco, objetivado enquanto doente, no interior ou fora do manicômio, é também, e a um só tempo, produto e testemunha fidedigna da psiquiatria. Dessa forma, a negação da ciência psiquiátrica como ideologia inscreve o saber-fazer sobre a loucura e o processo saúde-enfermidade mental em um campo eminentemente ético, que resgata a dimensão das relações entre os homens, que problematiza a função social e política das tecnociências e dos técnicos, que devolve à loucura a possibilidade de uma dimensão plural. Além do mais, o psiquiatra e os técnicos da psiquiatria, enquanto socialmente reconhecidos como portadores de um saber sobre a loucura e os seres humanos, têm função ética singular ao renunciarem ao mandato social de exclusão, segregação e medicalização do sofrimento humano e das formas sociais de produção da anormalidade.

Os mitos da neutralidade, do distanciamento crítico e da autonomia da tecnociência são colocados em discussão no questionamento das relações entre ciência e poder. Como nos faz pensar Stengers (ibid., p.145-146):

As ciências dão a impressão de se desenvolverem de maneira autônoma em relação ao 'contexto' social, econômico, político. Nós, que fazemos parte do 'contexto', podemos certamente criticá-las, e até mesmo tentar entravar sua história, mas não intervir nessa história: somente os cientistas têm o poder de definir o que é científico.

142 A instituição negada, p.9-10. 
Para além da desconstrução do conceito de doença, Basaglia opera a desconstrução das técnicas e dos técnicos. Vale lembrar que, dentre os pontos fundamentais tomados no início da transformação em Gorizia, estão o questionamento da neutralidade e de produção da verdade das ciências, e o papel e a função do técnico na constituição da hegemonia (Slavich, 1989), ou seja, pôr em cena e problematizar a posição daquele que coloca as questões nas ciências, que se constitui no "segundo uso da complexidade", no entender de Stengers (1989:162-171).

Cumpre ressaltar que as contribuições de Basaglia são reconhecidas por muitos autores. Para Castel (1987:48), que a Franco Basaglia dedicou A Gestão dos Riscos:

se o movimento italiano parece ter ido mais longe no sentido de uma transformação revolucionária da prática psiquiátrica é, sem dúvida, porque ele ultrapassou o compromisso do hospitalar e do extra-hospitalar, o que o levou, ao mesmo tempo, a tomar ainda mais distância em relação ao profissionalismo médico.

Em outra ocasiāo, Castel (1978b:172), ainda em referência ao trabalho de Basaglia, entende que:

a 'negação' da instituição, a despeito de seu voluntarismo, leva mais a sério a realidade sociológica das estruturas asilares que as tentativas 'tecnocientíficas' para sublimá-las através de sua humanização, porque redescobre, em sua origem, a objetividade das relações de força que determina igualmente, nos demais domínios da vida social, o destino dos sujeitos sociais.

Para Fleming (1976:102-103), a experiência de Basaglia trata fundamentalmente de "negar o mandato social do psiquiatra, recusando toda e qualquer terapêutica que visasse atenuar as reações do excluído em relação àquele que exclui".

Para essa autora, a desmontagem do aparelho psiquiátrico operada por Basaglia não busca, em qualquer das hipóteses, renovar ou aperfeiçoar o sistema hospitalar, como é o caso das experiências reformadoras anteriores.

No entanto, Birman (1982:240) considera:

é muito importante a maneira pela qual Basaglia encaminhou suas démarches para a ruptura com o quadro asilar (...). A questāo estaria exatamente em se ficar neste sistema normativo e em se acreditar que o problema se restringiria a uma nova tecnologia da cura. (...) Apenas com isso seria possivel constituir um saber sobre a loucura, obstaculizado desta forma. (...) Com efeito, não cabe apenas pensar a relação com a loucura em 
termos de cura, pois isso seria continuar no mesmo campo ideológico tradicional que a identificou com a doença mental, mas procurar transformar a relação da sociedade ocidental com a loucura, que está cristalizada no asilo e na exclusão social, já que constituem elementos fundamentais de controle da marginalidade social e de suas implicaçōes políticas. Aqui, portanto, o conceito de doença mental está claramente em questão, o que não estava anteriormente. Cabe, inclusive, desinstitucionalizar a doença mental para apreendê-la de uma outra forma, e conferir a ela um outro destino social.

Ainda para Birman, a experiência de Basaglia em Gorizia se constitui expectativa mais radical que a da antipsiquiatria, voltando-se para o questionamento das formas asilares de institucionalização da doença mental (idem). Mais adiante, em referência à comunidade terapêutica nos moldes postulados por Maxwell Jones, este autor afirma (ibid., p.240-241):

Basaglia chega mesmo a postular que, para a constituição de um saber psiquiátrico efetivo sobre a doença mental, seria preciso romper com esta experiência de exclusão (...). Basaglia, inclusive, nos últimos anos de sua reflexão, voltou-se para pensar as práticas sociais das técnicas do saber prático numa legítima linha gramsciana, interrogando o lugar dos intelectuais na constituição da hegemonia. Evidentemente, estava, com isso, interessado em pensar o lugar da psiquiatria no estabelecimento desta hegemonia.

Essas observações, assim como a de muitos outros autores, são baseadas sobretudo no período goriziano ou, mais especificamente ainda, no livro A Instituição Negada, enquanto a produção posterior, especialmente a do período triestino, no qual se inclui a dos autores pós-basaglianos, é praticamente desconhecida ou talvez não mereceu a atenção que, se procura demonstrar, deveria merecer.

A ruptura com o princípio da exclusão abre um campo de possibilidades que permite reinscrever a experiência da sociedade para com o louco e a loucura. No entanto, essa ruptura não é um processo, nem prática nem teoricamente simples. Basaglia atenta para o fato de que, em Gorizia, "estão perfeitamente conscientes do risco que estamos correndo: ser esmagados por uma estrutura social baseada na norma por ela própria estabelecida e fora da qual se submete às sanções previstas pelo sistema" ${ }^{143}$

143 Le istituzione della violenza, escrito em 1968, como parte de L'istituzione negata (BASAGLIA, Franco, 1981:504). 
É evidente que a negação não afasta a possibilidade, concreta e insofismável, de reinstitucionalizar o doente e os conceitos que sobre ele são produzidos. ${ }^{144}$

Para Rotelli (1990:90-91):

negação da instituição, bem mais que o desmantelamento do manicômio foi e é a desmontagem desta causalidade linear e a reconstrução de uma concatenação de possibilidade-probabilidade: como toda ciência moderna nos ensina diante de objetos complexos. O projeto de desinstitucionalização coincidia com a reconstrução da complexidade do objeto que as antigas instituições haviam simplificado (e não foi por acaso que tiveram que usar de violência para consegui-lo).

A renúncia ao mandato terapêutico - simultaneamente um mandato de tutela, controle, segregação, tolerância, manutenção e ampliação do território psiquiátricomoderno - é a renúncia ao objetivo normativo do absolutismo racionalista. ${ }^{145} \mathrm{~A}$ negação, enquanto renúncia à vocação terapêutica no interior do manicômio, tem valor mais que simbólico, porque esse é o 'lugar' da violência explícita, mas também porque é no manicômio que, historicamente, a psiquiatria constrói seu mandato social e científico. Em resumo, o manicômio é o a priori concreto da psiquiatria, o que faz com que este seja um lugar prático e simbólico de eleição para o processo efetivo de desinstitucionalização, como o 'lugar' de nascimento e de desenvolvimento das condições históricas de possibilidade da psiquiatria.

O processo de desinstitucionalização implica "reconstrução da complexidade" do fenômeno loucura, que significa a superação das antigas instituições, com a ruptura do seu paradigma fundante, isto é, a ruptura da relação mecânica causa-efeito na análise da constituição da loucura (idem).

As estratégias de negação/superação da instituição psiquiátrica e, posteriormente, de invenção de um saber-fazer complexo, podem ser consideradas como constitu-

\footnotetext{
$144 \quad$ A instituição negada, p.315-316.

$145 \mathrm{Ou}$, como diria o barbeiro de Itaguaí, "o despotismo científico do alienista". O Alienista, p.40.
} 
intes de "ruptura"146 no campo psiquiátrico. A instituição negada surge da constatação da função real da psiquiatria como instrumento tecnocientífico de poder, com a conseqüente negação do valor exclusivo que ela pretende reservar ao seu saber sobre a loucura. A estratégia da destruição da instituição manicomial é uma ruptura não apenas para com a psiquiatria, mas para com todas as suas reformas. Ou ainda, poder-se-ia falar em metamorfose na ciência psiquiátrica, uma vez que esse processo adota prática de saber e de aplicação do saber que determina uma situação teórica completamente diferente, isto é, renova a concepção das relaçōes dos homens com a natureza e a ciência como prática cultural (Prigogine \& Stengers, 1984:1).

Essa ruptura dá origem a novo "dispositivo", 147 tanto em relação à psiquiatria tradicional - o dispositivo da alienação -, quanto em relação às psiquiatrias reformadas - o dispositivo da saúde mental,$-{ }^{148}$ que poderia, provisoriamente, ser denominado de dispositivo da desinstitucionalização. A escolha desse termo para caracterizar o novo dispositivo implica assumir que a desinstitucionalização não é um processo que dispensa instituições, como poderia ser entendido pela leitura do termo ao pé da letra.

Ou como atenta Venturini (1990:3):

146 Quanto ao conceito de ruptura: "Não acreditar que a ruptura seja uma espécie de grande deriva geral a que estariam submetidas, ao mesmo tempo, todas as formaçōes discursivas: a ruptura não é um tempo morto e indiferenciado que se intercalaria - não mais que um instante - entre duas fases manifestas; não é o lapso sem duração que separaria duas épocas e desdobraria, de um lado e de outro de uma falha, dois tempos heterogêneos; é sempre entre positividades definidas, uma descontinuidade especificada por um certo número de transformaçōes distintas. De modo que a análise dos cones arqueológicos tem por propósito estabelecer, entre tantas modificações diversas, analogias e diferenças, hierarquias, complementaridades, coincidências e afastamentos: em suma, descrever a dispersão das próprias descontinuidades". E mais adiante: "Da mesma forma, a ruptura não é, para a arqueologia, a finalidade de suas análises, o limite que assinala de longe, sem poder determiná-la nem dar-lhe uma especificidade: a ruptura é o nome dado às transformaçōes que se referem ao regime geral de uma ou várias formaçōes discursivas" (Foucault, 1972:212-214).

Quanto ao conceito de dispositivo, utiliza-se aqui a definição empregada por Foucault em Microfísica do Poder, na interpretação ipsis litteris de Vera Portocarrero: "Estamos considerando que o dispositivo demarca um conjunto decididamente heterogêneo que engloba discursos, instituiçōes, organizaçōes arquitetônicas, decisões regulamentares, leis, medidas administrativas, enunciados científicos, proposiçōes filosóficas, morais, filantrópicas. O dispositivo é a rede que se pode estabelecer entre estes elementos. Segundo Foucault, ele é de natureza essencialmente estratégica, supōe uma certa intervenção racional e organizada, estando, portanto, sempre inscrito em um jogo de poder, e estando, no entanto, sempre ligado a uma ou a configuraçōes de saber que dele nascem mas que igualmente o condicionam; 'É isto o dispositivo: estratégias de relaçōes de força, sustentando tipos de saber e sendo sustentadas por ele'" (cf. Foucault, 1982:244-247 apud PORTOCARRERO, 1990:11).

148 Ambas as denominações, 'dispositivo da alienação' e 'dispositivo da saúde mental', foram propostas por Portocarrero (1990:11). 
precisamos ter a consciência dos riscos ideológicos e da necessidade de se constituir as instituições da desinstitucionalização. Instituições destinadas a negar-se e reinventar-se continuamente, no jogo dialético entre consciência e falsa consciência.

É importante, uma vez mais, frisar que a escolha do termo deve-se à concepção que dele tem sido feita na tradição basagliana, que ultrapassa as concepções de desospitalização, abolição e de reformas administrativas, para reportar ao sentido da desconstrução do saber psiquiátrico.

A crítica ao conceito de doença mental torna-se objeto prático e teórico da desinstitucionalização. Nesse novo contexto, o objeto não está mais em equilíbrio, mas está, por definição, em estado de não-equilíbrio: a existência-sofrimento de um corpo em relação ao corpo social: "Esta é a base da instituição inventada (e nunca dada)" (Rotelli, 1990:90-91).

Se a doença é colocada entre parênteses, o olhar deixa de ser exclusivamente técnico, exclusivamente clínico. Então, é o doente, é a pessoa o objetivo do trabalho, e não a doença. Desse modo, a ênfase não é mais colocada no "processo de 'cura', mas no processo de 'invenção de saúde' e de 'reprodução social do paciente'”" (ibid., p.30).

A desinstitucionalização, nesse contexto, faz com que se veja que o problema da doença não é uma questão exclusivamente científica a encontrar explicação e solução na ciência, mas é também um problema técnico, normativo, social e existencial. Assim, a instituição inventada torna-se o conjunto de possibilidades de produção de vida e de reprodução social que não são apenas técnicas, mas sociais, políticas e existenciais.

A psiquiatria, ao ocupar-se da doença, não encontra o sujeito doente, mas um amontoado de sinais e sintomas; não encontra uma biografia, mas uma história pregressa; não encontra um projeto de vida, mas um prognóstico. ${ }^{149} \mathrm{~A}$ noção do duplo da doença mental reporta a questões de ordem prática de como, no interior do trabalho institucional, ou, genericamente, do trabalho terapêutico, torna-se possível agir de forma absolutamente diversa daquela operada pela psiquiatria, cuidando dos sujeitos concretos em sua existência-sofrimento, e não de suas doenças em abstrato.

149 "Não assim o ilustre Simão Bacamarte; frio como um diagnóstico, sem desengonçar por um instante a rigidez científica, estendeu os braços à dona, que caiu neles, e desmaiou". O Alienista, p.35. 
O primeiro passo da desinstitucionalização consiste em desconstruir o paradigma problema-solução, ou seja, a idéia da doença que precisa de cura, em torno da qual se legitima o 'isolamento', a medicalização, a tutela e a desqualificação do sujeito. Este, deixa de ser uma pessoa para tornar-se um doente, no qual toda a sua história de vida passa a ser a história de uma doença. O segundo passo da desinstitucionalização é o envolver e mobilizar, nesse processo, estes mesmos sujeitos enquanto atores sociais, enquanto protagonistas de suas histórias (De Leonardis, 1987:251-254).

Enfim, a desinstitucionalização é um complexo processo, a um só tempo prático e teórico que, decompondo o saber e o olhar clínico, caminha no sentido de aceitar o desafio da complexidade dos múltiplos planos de existência (Rotelli, 1990:98), inventando novas possibilidades de inscrição dos sujeitos no corpo social.

Quanto à questão dos resultados, o conceito de desinstitucionalização é, em si mesmo, um conceito de transição numa "fase de transição" (Santos, 1987). Nega e desconstrói - por um lado -, inventa e cria - por outro. O que se inventa e se cria é o novo, é o "depois" - como insiste Basaglia -, que não sabemos exatamente o que é, mas que está sendo construído. Não existe, portanto, uma teoria do novo: "a ciência que se dissesse produtora de uma teoria do novo conteria praticamente uma contradição nos termos" (Stengers, 1989:172).

Uma coisa é certa: o novo, o "depois", a realidade que se está construindo e inventando não deve ser exclusividade da ciência, como pretendia o projeto da modernidade. No entanto, esse projeto não parte do pressuposto de que a ciência está além do bem e do mal, ou que os técnicos são homens de ciência, e só de ciência, alheios ao "contexto" social. ${ }^{150}$

Costuma-se ouvir dizer que Basaglia era um empirista, um operador sem referência teórica. Os autores da psiquiatria moderna e contemporânea insistem nessa crítica, pois consideram que ele não utiliza, como marco teórico de suas críticas e projetos de transformação, o que seria o saber psiquiátrico. De fato, Basaglia não se perde em discussões psicopatológicas sobre os diagnósticos mais corretos, os procedimentos mais precisos de análise e anamnese, ou sobre a teoria etiológica mais defini-

150 "Homem de ciência, e só de ciência, nada o consternava fora da ciência; e se alguma cousa o preocupava naquela ocasião, se ele deixava correr pela multidão um olhar inquieto e policial, não era outra cousa mais do que a idéia de que algum demente podia achar-se ali misturado com a gente de juízo". O Alienista, p.26. 
tiva. Pode-se considerar que ele não tinha um projeto, por assim dizer, exclusivamente teórico: sua meta era trabalhar sobre a prática psiquiátrica, nela realizando uma profunda transformação de cunho prático, sobretudo nos fatos, menos que nas palavras.

Basaglia tinha uma quase-obsessão em provar que era possível uma outra prática psiquiátrica sem, contudo, abrir mão da teoria. Mas a teoria que ele vai construir para sua transformação vai-se apoiar em outros campos do saber que não aquele per se psiquiátrico, e sim filosófico e epistemológico. Sua concepção mesma em relação aos saberes é a que estes 'caminham' junto com as práticas, construindo-se mutuamente: são faces de uma mesma moeda.

Basaglia pretendia gerar não apenas saberes teóricos, mas cultura. Queria produzir novas práticas e políticas culturais na psiquiatria e na sociedade, no lidar com a loucura e a doença mental. Trabalhou, talvez, com uma visão excessivamente humanística da noção de 'sujeito', assim como com uma visão de 'saber' que, possivelmente pouco complexa, adotasse, ingenuamente, perspectiva de liberação absoluta da ideologia.

Com as questōes de seu tempo, Basaglia introduziu mudanças em sua época, mas, certamente, abriu perspectivas para o futuro. 


\section{Capítulo 4}

\section{A título de prosseguimento}

\section{Psiquiatrismo e formulação de interesses}

Escondida sob o manto da cientificidade, a psiquiatria é um instrumento tecnocientífico de poder, uma vez que delimita e constrói espaços sociais, posições, verdades e erros. Mas, para além do fenômeno da doença, e para além da questão da psiquiatria como campo per se de saber, colocam-se outras questões, que dizem respeito à organização de interesses que se dá em torno da doença e da psiquiatria, as quais devem ser levadas em consideração no momento em que se fala e se almeja uma reforma psiquiátrica.

A experiência da institucionalização modifica tanto o devir do louco quanto a forma do lidar e do representar social quanto à loucura. Essa modificação social dá-se não só para o louco que é submetido à experiência da institucionalização, mas para a loucura, enquanto fenômeno social e cultural. Enfim, o objeto torna-se mais uma vez modificado.

Mas as modificações simbólicas, na forma como a sociedade pensa determinado objeto natural e cultural, não são decorrentes, apenas, de certas demandas de ordem econômica, filosófica ou social, tomadas em seu sentido mais amplo de estrutura e superestrutura. São também delimitadas por interesses específicos que surgem a partir da construção ou modificação do objeto. Em analogia e por extensão a Castel,, ${ }^{151}$ poderíase denominar tais interesses de 'psiquiatrismo', assim entendido como a interrogação "da relação da psiquiatria com seus 'usos' sociais, sua inserção num contexto histórico" (Castel, 1978c:4), que produz "determinados efeitos específicos".

Desse modo, para além da questão da relação do conhecimento com o seu objeto, mesmo que supostamente isolados em um laboratório impenetrável de influências outras, impōem-se os valores sociais, morais e históricos dos saberes e de seus usos aí produzidos. Mas tal impenetrabilidade não ocorre, e isto conduz a uma redefinição

151 Para CAstel (1978c:3), psicanalismo é "a sombra projetada pela psicanálise, o que ela obscurece e o que a ela própria permanece opaco, no interior como no exterior do seu campo". 
da significação de conjunto da psiquiatria. Esse aspecto, das influências sociais, morais e históricas nos saberes, é radicalizado na psiquiatria, na medida em que, ela mesma, assim como o seu objeto - a doença-anormalidade mental - situam-se em uma "zona limítrofe" (Berlinguer, 1991) ou de fronteira, em que se torna ainda mais difícil, senão impossível, estabelecer distinções claras entre os objetos que são decorrentes de uma experiência cultural e suas condições históricas de conhecimento.

Desde a transformação de Bicêtre em asilo de alienados existem asilos privados que, assim, produzem demandas e administram, sob interesses próprios, a loucura. ${ }^{152}$ A lei francesa de 30 de junho de 1838 - primeira legislação sobre assistência aos alienados - versa minuciosamente sobre a prestação de assistência psiquiátrica nos estabelecimentos privados (Castel, 1978c:305-316).

A assistência psiquiátrica privada, de caráter predominantemente manicomial, é hoje um dos principais obstáculos à reforma psiquiátrica, não apenas por cultivar a cultura manicomial, mas, em igual proporção, por resistir às mudanças que ferem seus interesses. É absolutamente impossível pensar em uma reforma psiquiátrica no contexto da desinstitucionalização, tal como se a tem definido aqui, no âmbito dos serviços privados. A 'indústria da loucura', como ficou conhecida, contribui desmesuradamente para que as 'doenças psiquiátricas' ocupem o segundo lugar das internações hospitalares, por ano, no Brasil.

Uma outra formulação de interesses relaciona-se à indústria de medicamentos, que investe pesadamente na produção de agentes farmacológicos a tal ponto que atualmente coloca-se como um dos principais problemas de saúde pública, isto é, o da oposição entre uma "política de saúde" e uma "política de consumo" (Bermudez, 1991). No entanto, traz à discussão um aspecto vital no debate sobre a bioética, qual seja, a dos limites da pesquisa e da intervenção técnica no comportamento humano (Amarante \& Schramm, 1993). O aumento do território psiquiátrico - da patologização dos comportamentos sociais - é acompanhado também por novas possibilidades de medicalização, a exemplo do que vem ocorrendo com a denominada doença do pânico ou fobia social.

A Universidade reivindica a democratização das instituições de ensino e pesquisa, de assistência e de cooperação técnica, a autonomia na pesquisa e na produção de conhecimentos. Pede, ainda, o fim do autoritarismo do Estado na definição e condução 
das linhas e prioridades de investigação, na utilização da ciência e suas instituições a serviço da segregação e da violência social. Paradoxalmente, coloca-se passiva e submissa, quando não conivente, com o mesmo papel exercido pela indústria farmacêutica nos congressos de psiquiatria, nas pesquisas, nas publicações 'científicas' da área. A mídia, articulada pela indústria farmacêutica e seus agentes sociais - a categoria psiquiátrica - operam a associação obrigatória e insubstituível entre tratamento e prescrição de medicamentos, procurando demonstrar a falência de outras modalidades de cuidados. Aqui, coloca-se ainda a questão da pesquisa, exacerbada nos países onde são raros os recursos para a investigação no campo social e sanitário. A Universidade não faz mais que acatar e reproduzir a bibliografia produzida pela/ou com o patrocínio da indústria farmacêutica. Saraceno (1993:164-165) atenta para a precária atitude crítica dos "receitantes" em relação à informação e aceitação passiva da informação, que atribui aos seguintes fatores:

- o poder econômico da indústria farmacêutica determina uma forte, abrangente e firme difusão de informações distorcidas;

- o poder econômico da indústria farmacêutica determina uma 'cumplicidade intelectual' de muitos líderes de opinião que produzem informações; - o poder econômico da indústria farmacêutica determina estratégias informativas simplificadas, seguras e apetitosas para os receitantes e, às vezes, para o paciente que receberá a prescrição;

- o poder cultural e o condicionamento econômico de muitas instituições privadas ou públicas de pesquisa farmacológica determinam uma cumplicidade na produção da pesquisa que, mesmo se formalmente correta do ponto de vista metodológico, é freqüentemente repetitiva, auto-reprodutiva e irrelevante para a saúde pública.

Contudo, as práticas que vão contra a qualificação efetiva do campo da saúde mental não se restringem à ação da indústria farmacêutica; podem ser estendidas à indústria de equipamentos e tecnologias, que têm tido notável crescimento com o advento das neurocirurgias - a exemplo das lobotomias, do eletroencefalograma e da eletroconvulsoterapia - e que, agora, incursionam pelo campo da engenharia genética.

Um outro aspecto diz respeito às corporaçōes profissionais. Os médicos franceses, já por ocasião do 'gesto de Pinel', denunciam a lutam contra o crescente privilégio que os alienistas, estes primeiros especialistas da medicina, vêm recebendo do sistema público de saúde. A interdisciplinaridade no campo da saúde mental fez proliferarem as profissões, especialidades, técnicas e terapias que, em suma, contribuem para aumen- 
tar o teclado de 'problemas emocionais' suscetíveis de intervenção técnica. As multidisciplinaridades, como atenta Basaglia, servem mais para aumentar o mercado e o território dos desvios e anormalidades que para contribuir para uma recomplexificação dos fenômenos em questão.

Evidente que todo esse conjunto de interesses, dentre outros, contribui para a manutenção de determinados procedimentos e desenvolvimentos que promovem mudanças culturais e sociais, por exemplo, no imperativo da 'hospitalização' ou da necessidade de consumir medicamentos, no fazer exames, no fazer terapias, ao que tudo se soma na construção das representações sociais quanto à natureza da loucura.

Entretanto, devemos buscar demarcar limites não apenas políticos, mas sobretudo éticos, de "até onde pode e deve ser tolerada" a pesquisa, nos seres humanos, sob a égide do lucro, do mercado, dos limites éticos; de até onde pode avançar o processo de medicalização, quanto à intervenção biológica no corpo não apenas individual, mas social, e não apenas social, mas na natureza da "humanitude", nas palavras de Albert Jacquard (1986).

Por tais razões, impõe-se a ampliação da analogia estabelecida com a noção de psiquiatrismo, com o objetivo de possibilitar a inclusão da formulação de interesses no campo da loucura, do sofrimento psíquico, do desvio e da psiquiatria como prática social, econômica e política, na medida em que tal disciplina ou, ao menos, muitos técnicos da 'saúde mental' insistem em dizer que fazem apenas ciência, só ciência, nada mais que ciência.

\section{Reforma psiquiátrica: a utopia antimanicomial e a ética da desinstitucionalização}

Como se pode atualmente reconhecer, o problema é construído pela solução que dele se tem. A simplificação da loucura enquanto objeto, como inicialmente operada por Pinel, tem como base a experiência empírica de Locke, para quem a sensação é suficiente para captar a realidade e formar conceitos que, se não a traduzem fielmente, ao menos dela se aproximam o suficiente. Com a percepção e a nominação do real, do modo como bem determina a História Natural, Pinel parte da idéia de que o conhecimento é esse conjunto de sensações do objeto decomposto em suas partes simples, e que basta recompor as simplicidades para reconstruir a complexidade do objeto. Dito 
de outra maneira, o conjunto de delírios, alucinações, enfim, de sinais e sintomas, expressam a loucura em sua essência. Embora procurando seguir o caminho inverso ao de Descartes, que "vai da idéia para as coisas" (Santos, 1987:14), o alienismo vai das coisas para a idéia, acreditando que esta pode, assim, superar a subjetividade do observador. Mesmo considerada a intermediação do observador, acredita-se, ainda, que este pode controlar até que ponto vai sua intervenção, e distanciando-se e evitando interferir com sua subjetividade permite-se conhecer o objeto em sua quase plenitude.

A psiquiatria, pretendendo-se uma ciência, a exemplo e tal qual pretende-se também a medicina calcada na anatomopatologia, promove a redução da complexidade do fenômeno a estruturas psicopatológicas concebidas sobretudo a partir da "percepção médica" (Foucault, 1978), ou seja, da percepção socioculturalmente determinada, que informa os primeiros momentos do saber psiquiátrico. De certo modo, ao construir as síndromes psicopatológicas, o faz baseada fundamentalmente nos aspectos ditos 'negativos' da estrutura mental (alienação, desrazão, incompreensibilidade, periculosidade, incapacidade e assim por diante), informada pelo tipo de percepção social que se tem da loucura. Enfim, a psiquiatria não consegue estabelecer diálogo com a loucura, senão para constatar a sua absoluta estupidez. ${ }^{153} \mathrm{~A}$ estupidez é, aqui, radicalizada, uma vez que a loucura significa não-natureza, ou natureza deturpada. Se o alienado não é senhor de si, não é sujeito, não é capaz de exercer sua liberdade, deve ser tutelado, dobrado e administrado, e nisso consiste o tratamento moral.

Estabelecendo outra analogia com Prigogine \& Stengers, como resultado da 'positivação' da natureza, dá-se que a razão, estranha à loucura, se apresenta como sua senhora, num processo de "desencantamento" que impossibilita um verdadeiro diálogo entre o saber e o objeto do saber. ${ }^{154}$ É dessa forma que, perdendo o mito, a fantasia, o encantamento, a loucura pode, ao mesmo tempo, ser enquadrada em regras gerais e

153 Estabelece-se, aqui, uma analogia com Pricocine \& Stencers, (1984:4), para quem “... o homem do século XVII não conseguiu se comunicar com a natureza senão para descobrir a terrificante estupidez de seu interlocutor".

154 "O mundo desencantado é, ao mesmo tempo, um mundo manejável. Se a ciência concebe o mundo como submetido a um esquema teórico universal que reduz suas diversas riquezas às melancólicas aplicações de leis gerais, ela se dá, da mesma forma, como instrumento de controle e de dominação. O homem, estranho ao mundo, se apresenta como senhor deste mundo" (PriGoGiNE \& Stencers, 1984:22). Com relação à noção de desencantamento do mundo, consultar também Weber (1982:165-166), para quem dizer que o mundo foi desencantado "significa principalmente, portanto, que não há forças misteriosas incalculáveis, mas que podemos, em princípio, dominar todas as coisas pelo cálculo. (...) já não precisamos recorrer aos meios mágicos para dominar ou implorar aos espíritos, como fazia o selvagem, para quem esses poderes misteriosos existiam (...)". 
em espaços de reclusão/modificação. Mesmo que o princípio dos revolucionários franceses fosse o reconhecimento da possibilidade de cura para a loucura, tal possibilidade era dada pelo 'isolamento', o qual significa tão-somente reclusão e violência.

Para Santos (1987:12-13), os principais traços do paradigma científico surgido a partir do século XVI e desenvolvido basicamente no domínio das ciências naturais, são: primeiro, a distinção por ele mesmo estabelecida com os conhecimentos não-científi$\cos -\mathrm{e}$, portanto, irracionais, em que o senso comum e os estudos humanísticos, dentre os quais os estudos históricos, filológicos, jurídicos, literários, filosóficos e teológicos; segundo, o seu caráter totalitário, "na medida em que nega o caráter racional de todas as formas de conhecimento que não se pautarem pelos seus princípios epistemológicos e pelas suas regras metodológicas".

Ao receber o estatuto científico de alienação mental, a loucura passa a ser submetida a um processo que a faz perder toda e qualquer expressão que não seja aquela da racionalidade médica. Essa positividade que afirma que a loucura não é nada além de uma doença - portanto, uma deficiência -, oferece à sociedade uma forma específica, por que não dizer restrita, no lidar com a loucura. Como doença mental, como verdade médica, o lidar social será marcado pelo saber psiquiátrico, que determinará 'o que fazer', 'como', 'quando e onde' com a pessoa do louco.

A psiquiatria desvaloriza, assim, os saberes sobre a loucura, pois não há saber verdadeiro que não provenha da ciência. Munido da utopia da neutralidade e do distanciamento, insuperáveis em sua globalidade, porém controláveis pela razão do sujeito do conhecimento, Pinel pôde propor o "isolamento" dos alienados, sem estabelecer a função social que este cumpre com a ordem que se instaura. ${ }^{155}$

O 'isolamento' - a imposição da reclusão - é o instrumento mais marcante da psiquiatria, e não o é por outra razão que não a função social que a acompanha desde o nascimento até os dias atuais. Da reforma das colônias, com seu princípio de 'ilusão da liberdade', passando pela psicoterapia institucional, com o revigoramento da 'casa de cura', às demais experiências reformadoras, o 'isolamento' permanece na base da prática psiquiátrica.

Se a operação de transformação da loucura em doença mental impõe, por si mesma, um determinado afastamento entre o 'objeto natural' e o 'objeto científico', as práticas culturais, sobredeterminadas por tal transformação, procedem a outra opera- 
ção que imprime novos valores culturais ao objeto do conhecimento. Ou seja, d verdade científica insere mudanças no modo cultural de lidar com o objeto, que, de uma parte, anula certas concepções anteriores à descoberta científica e, de outra, reinterpreta os valores dessa mesma descoberta a partir de suas próprias concepções anteriores à descoberta.

Assim feito, o objeto é transformado pela nova experiência social, que o devolve ao saber científico com as marcas da transformaşđu. Um nítido exemplo dessa operação é o princípio da reclusão dos loucos, imperativo jurídicu-legal da Grande Internação, que transmuta-se no princípio do isolamento, imperativo médico para a loucura, tornada doença mental, que torna-se ainda imperativo social de higienização e disciplinamento do espaço coletivo. Se a psiquiatria afirma que o alienado deve ser isolado, submetido a uma pedagogia moral e - mais que isso - sobre ele exerce, na prática, uma ação de violência, abandonando-o nu e imundo no pátio de um manicômio, é porque - pode-se concluir - é ele um ser perigoso, nefasto, incapaz, um nãoser. O 'estigma', socialmente construído, é radicalizado pela intervenção da psiquiatria, que afirma ser o alienado ainda mais deteriorado do que já percebido pela sociedade.

De Pinel a Kraepelin existe uma visível evolução nos conceitos psiquiátricos, como reivindicam os modernos tratados de psiquiatria. Debates sobre etiologias, nosologias, terapêuticas, contudo, não são suficientes para mudar o principal e miserável destino dos loucos: os asilos, a estigmatização e a invalidação social.

Incapaz de chegar à pretendida definição do que seja a alienação mental, a psiquiatria, no entanto, mantém sua posição originária de falar sobre a sociedade, as relações humanas, a natureza humana, e muito pouco ou quase nada sobre os sujeitos concretos que adoecem. Se a alienação pode ser efeito de um distúrbio das paixões, ou se o desvio pode ser efeito da causa degenerescência, a psiquiatria pretende dar conta, isoladamente, de um complexo mundo de relaçōes e fatores relacionados à natureza humana. A ausência de lesão física não a intimida quanto a oferecer compreensão psiquiátrica, portanto patológica, deste ou daquele tipo de comportamento, deste ou daquele devir, desta ou daquela forma de se relacionar com o mundo. O mundo da psiquiatria é o mundo das doenças, a doença implica solução médica. A cultura, a sociedade e as crenças servem à psiquiatria não como saberes e formas de vida, mas somente como meio no qual se constituem doenças e no qual estas se proliferam.

E não é apenas o louco manicomializado que tem destino miserável. A categoria 'louco', 'doido', 'maluco' é negativamente estigmatizada e, nesse processo, a psiquiatria tem muita responsabilidade. Ao definir o estatuto jurídico da doença mental (os 
loucos de todo gênero), ela legitima a condição de não-cidadão, de não-sujeito do doente. Internado ou não em um manicômio, o louco é despossuído de seus direitos, não apenas sociais, civis e políticos, mas de ser uma pessoa, de ter seus desejos e projetos.

Isso não é o bastante. A psiquiatria coloca seu saber pretensamente científico que, como se viu, consiste não mais que descrever e interpretar, à luz dos valores dominantes, aquilo que é socialmente bizarro, excêntrico e estranho - à disposição daqueles mesmos valores, para ampliar o conceito de doença. Com essa ampliação, aumenta a possibilidade de estigmatização, de intervenção social sobre segmentos cada vez maiores, sobre a 'maioria desviante'.

Ora, o louco que se asila e tutela, o desviante que se tolera e normatiza não é uma pessoa apenas, mas uma 'classe de gente' que é colocada sob essa percepção, que é submetida a essa intervenção técnica, a essa invalidação social e a esses interesses privados.

O processo de reforma psiquiátrica deve remeter a toda ordem dessas questões, se se pretende romper com as práticas a as funções da psiquiatria moderna. Em certo sentido, deve, inicialmente, desmascarar a legitimidade científica da psiquiatria e das psiquiatrias reformadas. O ideal do bom manicômio, da 'casa de cura' - presente nos projetos da comunidade terapêutica e nos da psicoterapia institucional -, e o ideal da saúde mental - presente nas psiquiatrias de setor e na preventiva ou comunitária -, devem ser desmascarados, negados e combatidos como estratégias que visam à manutenção da violência institucional, da medicalização, da simplificação do fenômeno da experiência complexa do sofrimento em doença mental.

A utopia da sociedade sem manicômios reporta a uma importante inflexão, a um só tempo epistemológica e ética: é, simultaneamente, possível e impossível, mas já insere novo dado em um processo de invenção de outra realidade:

E por isto estas experiências de desinstitucionalização são agentes de mudança social, produtores daquela realidade - social, econômica, científica, cultural e institucional - caracterizada pela noção da ausência do manicômio. (De Leonardis, 1987:257)

O conceito de cidadania dos doentes mentais, implícito no discurso e na prática de Basaglia, se relaciona à ampliação dos direitos sociais, jurídicos e políticos dos mesmos. Mas não apenas isso, porque, de tal concepção, são muitos os que dela partilham. Melhor dizendo, não se trata de, com base na idéia de cidadania como valor universal, admitir sua extensão a todo o tecido social. Trata-se, sobretudo, de ampliar ou diversi- 
ficar, em um prático trabalho de desinstitucionalização, o próprio conceito de cidadania, no sentido de admitir a pluralidade de sujeitos, com suas diversidades e diferenças num mesmo patamar de sociabilidade. Trata-se, ainda, não de deixar o louco viver a sua loucura, porém de, em um novo contexto de cidadania, dar-Ihe o real direito ao cuidado. Não de ser excluído, violentado, discriminado, mas de receber ajuda em seu sofrimento, em sua positividade e em sua possibilidade de ser sujeito. Enfim, trata-se de trabalhar efetivamente para que ele seja um sujeito de desejos e projetos.

A desinstitucionalização é um processo ético porque, em suma, inscreve-se em uma dimensão contrária ao estigma, à exclusão, à violência. É manifestação ética, sobretudo, se exercitada quanto ao reconhecimento de novos sujeitos de direito, de novos direitos para os sujeitos, de novas possibilidades de subjetivação daqueles que seriam objetivados pelos saberes e práticas científicas, e inventa - prática e teoricamente - novas possibilidades de reprodução social desses mesmos sujeitos. 



\section{Anexo 1}

\section{Conselhos moraes para a conduta da vida}

Foge das pompas loucas da vaidade, Das glórias vãs o animo retira; Abraça os documentos da verdade, Abomina os erros da mentira;

Aborrece do engano a falsidade,

Não to deixes vencer do ódio, ou ira,

Nos faustos vãos do mundo nunca cuides,

Não desejes mais honras que virtudes.

Não descubras a falta que souberes, Aspira sempre as cousas superiores, Cuida primeiro em tudo que fizeres; Trata com teus iguaes, honra os maiores;

Dá com mão liberal tudo o que deres, Vai prevenido, onde quer que fores, Procede em tudo recto, e sem engano, Nada executes por respeito humano.

Busca para conselho o mais prudente, Supporta as afflicções sempre constante, De nenhum modo sejas mal dizente, Não te jactes com animo arrogante;

Nas práticas não sejas imprudente, Nunca digas palavras mal soante, Falla de todos bem, sem fazer damno, Ouve mal da lisonja o doce engano. 
Conserva da virtude a inteireza,

Não te deixes levar da vil cobiça,

Nada executes obrando com vileza,

Foge da formosura que enfeitiça;

Da tua alma não manches a pureza,

Por respeitos não faltes á justiça;

De teus rectos propositos não mudes,

Obrando bem, do que dirão não cuides.

Mostra-te sempre o mesmo em qualquer sorte,

Foge do damno, no perigo adverte,

Vence as adversidades sempre forte,

Deixa o amigo máo, que te perverte;

Prepara-te na vida para a morte,

Não dilates a emenda, que é perder-te;

Trata dos mais, de ti não te desculpes,

A todos na afflicção benigno ajudes.

Aceita quando errares a advertencia,

Foge quando acertares da jactancia;

Não uses mal dos bens tendo opulencia,

Mostra nos males ter igual constancia;

Preza-te da fiel correspondencia,

Teme de ter encargos na ganancia,

Mostra-te para todos mui urbano,

Usa sem fingimento um trato Ihano.

Sabe buscar um amigo verdadeiro,

Foge á toda a perversa companhia,

Em fazer bem procura ser primeiro,

Não sejas enfadoso na porfia;

Não te chegue a cobiça do dinheiro,

Domina as paixões com valentia,

Tira no damno alheio o desengano,

Vence do proprio amor o grande damno. 
Procura nos amigos a igualdade, Acautela-te sempre do inimigo, Ao miseravel trata com piedade, Vendo o alheio, evita o teu perigo; Se queres viver bem, trata a verdade, Foge á lisonja do fingido amigo, Nunca do que te importa te descuides, Nas sortes ambas o animo não mudes.

Não estragues com vicios a saude, Os olhos põe na larga Eternidade, Os augmentos procura da virtude, Vê que passa mui breve a longa idade; No que não podes busca quem te ajude, Nunca faças assento na maldade, Levanta-te do vicio em que tropeças, Podendo escusar a ninguem peças.

Se vires que vai bem passa adiante, Volta atrás se vais mal encaminhado,

Seja o fim ao principio semelhante, Acaba bem, se bem tens começado; Dá sempre mostras de animo constante, Porta-te nos perigos alentado, Não mostres nunca de fraqueza indicio, Arroja-te corn gloria ao precipicio.

Não sejas nas desgraças mal soffrido, Sabe sempre triumphar do adverso fado, Não desanimes vendo-te abatido, Não te presumas mais quando elevado; Vê, se o que queres tens bem merecido, Nas pretensões procede acautelado; 
Nada a que for injusto a ninguem peças,

Não ocupes lugar que não mereças.

A quem te fizer mal não faças damno,

Preza-te nas occasiões de generoso,

Dissimula os aggravos sempre humano,

Não sejas da vaidade ambicioso;

Aos humildes não traves soberano,

Agradece a quem deves primoroso,

Nunca de ingrato dês nem leve indicio,

Paga com outro maior o beneficio.

Sem maduro conselho nada faças,

O que for de segredo a ninguem digas,

Do teu arbitrio não te satisfaças,

A pretensão procura que consigas;

Na fama de ninguem nunca desfaças,

Nos erros começados não prossigas,

Não queiras premios ter que não mereças,

O fim olha das cousas que começas.

Trata de viver bem, que a morte é certa,

Olha que has de morrer e é breve a vida,

No mais ditoso bem feliz se acerta,

Tendo a alma de Virtudes prevenida;

Cuida naquela hora sempre incerta,

Vê bem não erres a última partida,

Foge ao perigo, evita o precipicio,

Louva o alheio bem, nota o teu vicio.

Mello Moraes, Physiologia das Paixões e Affecções, 1855. 


\section{Anexo 2}

\section{Franco Basaglia: pequena biografia de um ideal de vida}

Em Veneza, no ano de 1924, nasce Franco Basaglia. E nessa cidade, ainda estudante, milita na Resistência Italiana, quando é preso até o final da Segunda Grande Guerra. Terminada a guerra, Basaglia ingressa na Faculdade de Medicina de Padova e, após 12 anos de vida acadêmica, decide abandonar a Universidade para trabalhar no Hospital Psiquiátrico Provincial de Gorizia.

Os muitos meses de prisão fazem com que perceba as cruéis condições a que são submetidos os institucionalizados - o que, imediatamente, associa aos internos do hospital psiquiátrico - e apontam para um ideal de vida que vai perdurar até os seus últimos dias: a transformação radical das práticas e das instituições psiquiátricas.

Já em 1961, ano em que ingressa na Direção do Hospital de Gorizia, Franco Basaglia inicia as mudanças, melhorando as condições de hospedaria e cuidados técnicos para com os internos. Por sua marcante formação humanística e filosófica, mais precisamente no campo da fenomenologia e do existencialismo, procura abordar a doença mental no contexto da

relação do indivíduo com o seu corpo, sua maneira de vivê-lo, objetivá-lo e de ser fundamentalmente sujeito da experiência corporal. Prisioneiro da ótica positivista da qual ainda hoje a cultura médica é impregnada, o corpo resulta pura inércia e passividade. É preciso superar a nítida dicotomia alma e corpo, criando uma possibilidade de conquista de uma subjetividade para que este corpo possa apropriar-se, opor-se a sua sistemática objetivação realizada pelo método naturalístico. (Basaglia, Franca apud Barros, 1994:58)

Mas o contacto com a realidade institucional desvai essa possibilidade, levandoo a se perguntar: "Como fazer emergir o sujeito desta humanidade humilhada, destes corpos torturados, destas vidas interrompidas?" (idem).

As mudanças internas na instituição são assim levadas às últimas conseqüências, com a abolição completa dos métodos coercitivos e violentos, com o resgate dos direitos e da dignidade dos internos, mediante as ativas participações nas reuniōes e assem- 
bléias. Os primeiros pavilhões começam a ser abertos, mobilizando a comunidade local em prós e contras, mas, em última instância, devolvendo a discussão e a responsabilidade dos doentes e da instituição à sociedade, que havia subtraído de si essa questão.

Nos anos finais da década de 60, em meio ao clima revolucionário dos movimentos estudantil e operário que envolvem a Europa, o trabalho de Gorizia ganha repercussão em vários países. A discussão sobre a violência institucional, a segregação e o autoritarismo aproximam os operadores e os pacientes de Gorizia dos movimentos sociais mais significativos.

Em 1968, com base na constatação de que o hospital psiquiátrico não servia à terapêutica, mas ao controle social de determinados segmentos marginalizados, Franco Basaglia lidera a iniciativa de fechamento do hospital provincial. A equipe técnica encaminha à administração municipal uma reivindicação para que as atividades do hospital sejam definitivamente encerradas, o que é rejeitado pelo poder local. Como resultado, a equipe dá alta coletiva aos internos e se demite em massa.

O hospital termina por ter uma nova direção, que readmite muitos dos internos e o retrocesso torna-se visível. Entretanto, a repercussão da experiência de Gorizia mobiliza muitos técnicos em várias cidades italianas e, até mesmo alguns meses depois, na própria Gorizia, a experiência é retomada.

A repercussão dessa experiência significou também um importante convite e, em 1969, Franco Basaglia parte para os Estados Unidos da América como professor convidado em um Mental Health Center, tendo a possibilidade de conhecer de perto a famosa 'terceira revolução psiquiátrica': a psiquiatria comunitária.

Em 1970 Franco Basaglia retorna à Itália e, em Parma, inicia nova experiência, procurando "fragmentar o manicômio em inúmeros núcleos autônomos", recusada pela administração provincial (Basaglia, Franca O., 1993:47). Decide, assim, partir para Trieste, onde em 19 de agosto é nomeado diretor do Hospital Psiquiátrico Provincial, com 1.200 internos, dos quais cerca de 900 sob tutela judicial, onde elabora um programa de profundas transformaçōes. ${ }^{156}$

Em janeiro do ano seguinte consegue, da administração local, a concessão de subsídio em dinheiro para os pacientes em alta encarregarem-se dos próprios tratamentos. Em março desse mesmo ano é inaugurada a primeira cooperativa de trabalho de pacientes - a Cooperativa dos Trabalhadores Unidos-, dedicada a tarefas de limpeza, 
não apenas do próprio hospital, mas com contratos externos. Ainda nesse ano, em dezembro, é fechado o primeiro pavilhão, o P, cujas instalações serão destinadas, posteriormente, à sede administrativa e às oficinas e ateliês das cooperativas: o Laboratório P. A idéia desse Laboratório nasce na festa de natal de 1972, na casa de Basaglia, com o princípio de realizar um trabalho coletivo de caráter cultural no hospital de Trieste. Um grupo de pessoas presentes decide colocar-se à disposição desse trabalho coletivo; são pintores, escritores, animadores culturais, professores, diretores de teatro e cinema, fotógrafos, enfim, de variadas inserçōes no mundo cultural, que decidem oferecer suas experiências para o desenvolvimento de um trabalho cultural no hospital.

O ano de 1973 começa com uma importante inovação: o surgimento da categoria 'hóspede'. Esta é reservada aos internos que, por não terem justificativa psicopatológica para permanecerem internados, mas que não tendo também recursos próprios para uma subsistência autônoma, recebem alta médica. A administração lhes cede um quarto ou apartamento no espaço do hospital, em decorrência da dívida social do Estado para com essas pessoas. Sendo hóspedes podem entrar e sair, ter as chaves do cômodo, do armário; não estão mais sob tutela ou tratamento coercitivo. Além do espaço para morar, aos hóspedes são oferecidos subsídios em dinheiro para subsistência.

Após curto período de funcionamento do Laboratório P, o grupo decide promover uma grande atividade cultural que caracterizasse o trabalho de transformação levado a cabo no hospital. De alguns internos veio a idéia de homenagear um velho cavalo que trabalhava no espaço da instituição e que, agora, devido à idade, estava abandonado e com risco de ser morto pelo ônus que representava. Coincidência ou não, Marco (este era seu nome) significava, de certa forma, a condição de todos os segregados pela sociedade e, então, foi o tema escolhido para a atividade. Sobre uma estrutura metálica construiu-se um grande cavalo de papier machê, assim como o Cavalo de Tróia, o qual, pela primeira vez, acompanhou a saída em massa dos internos, técnicos e simpatizantes do movimento, pelo interior da cidade.

Marco Cavalo torna-se, assim, símbolo do processo de liberalização e de retorno à cidade, de todos aqueles cujo manicômio havia seqüestrado essa possibilidade.

Prossegue-se com o fechamento de mais pavilhões e, ainda, das oficinas de ergoterapia, que dão lugar a novas cooperativas de trabalho.

Malgrado a forte oposição e críticas a esse processo, a Organização Mundial da Saúde (OMS), ainda em 1973, credencia o Serviço Psiquiátrico de Trieste como referência para a pesquisa no âmbito da saúde mental. 
Em janeiro de 1975, é aberto o primeiro Centro de Saúde Mental, em Aurisina, com o objetivo de dar início à rede de serviços territoriais verdadeiramente substitutiva ao hospital psiquiátrico especializado. A partir daí são implantados os demais seis Centros. Estes, diferentemente de outros centros de saúde mental experimentados na Itália ou em outros países, passam a oferecer atenção integral, nas 24 horas do dia e 365 dias do ano, com acolhimento de crise, atendimento domiciliar e apoio social. Formam a base técnica e social territorializada para o programa de desinstitucionalização.

Em 1976, o Hospital Psiquiátrico de Trieste é oficialmente fechado, não aceitando mais novas internações. Toda a assistência passa a ser realizada a partir dos centros territoriais, das cooperativas, dos grupos-apartamento e do serviço de emergência do Hospital Geral.

Em 13 de maio de 1978, por todo o debate e repercussões provenientes do trabalho conduzido por Basaglia em Trieste, é aprovada a Lei n 180 - ou Lei da Reforma Psiquiátrica Italiana -, que fica popularmente conhecida como 'Lei Basaglia'.

Em novembro de 1979, Franco Basaglia deixa a direção do hospital em Trieste, sendo substituído por Franco Rotelli, e parte para a região do Lazio, cuja capital é Roma, para dar início à implantação da reforma.

Em agosto de 1980, aos 56 anos, morre na mesma cidade em que nasceu. 


\section{Referências bibliográficas}

Amarante, P. Psiquiatria social e colônias de alienados no Brasil (1830-1920), 1982. Dissertação de Mestrado, Rio de Janeiro: Instituto de Medicina Social/Universidade do Estado do Rio de Janeiro.

AmARANTE, P. A (ainda) atualidade da psiquiatria democrática italiana. Saúde em Debate, 29:77-80, 1990a.

Amarante, P. Dossiê sobre o Movimento dos Trabalhadores em Saúde Mental no Brasil. Relatório de Pesquisa, Rio de Janeiro: Nupes/Daps/Ensp/Fiocruz, 1990b.

Amarante, P. (Org.). Análise dos Determinantes e Estratégias das Políticas de Saúde Mental no Brasil: o projeto da reforma psiquiátrica (1970-1990). Relatório de pesquisa, Rio de Janeiro: Nupes/Daps/Ensp/Fiocruz, 1993.

Amarante, P. Prefácio: A tradição basagliana e a invenção de uma nova psiquiatria. In: Barros, D. D. Jardins de Abel: desconstrução do manicômio de Trieste. São Paulo: Lemos/Edusp, 1994a. p.17-20.

Amarante, P. Uma aventura no manicômio: a trajetória de Franco Basaglia. História, Ciências, Saúde - Manguinhos, 1(1):61-77, 1994b.

Amarante, P. (Org.). Psiquiatria Social e Reforma Psiquiátrica. Rio de Janeiro: Ed. Fiocruz, 1994c.

Amarante, P. (Coord.). Loucos pela Vida: a trajetória da reforma psiquiátrica no Brasil. Rio de Janeiro: Ensp/Fiocruz (Coleção Panorama), 1995. [2.ed. revista e ampliada - Rio de Janeiro: Ed. Fiocruz, 1998] 
Amarante, P. \& Schramm, F. R. Norma umana e biologia. In: Rodotà, S. (Org.) Questioni di Bioetica. Roma: Sagittari Laterza, 1993. p.386-396.

Artaud, A. O Teatro e seu Duplo. São Paulo: Max Limonad, 1987.

Bachelard, G. O Novo Espírito Científico. Rio de Janeiro: Tempo Brasileiro, 1985.

Barros, D. D. Jardins de Abel: desconstrução do manicômio de Trieste. São Paulo: Lemos/Edusp, 1994.

Basaglia, Franca O. (Org.). Basaglia Scritti I (1953-1968) - dalla psichiatria fenomenologica all'esperienza di Corizia). Torino: Einaudi, 1981.

BASAGLIA, Franca O. Introduzione generale ed esposizione riassuntiva dei vari grupi di lavori. In: BASAGLIA, Franca O. (Org.) Basaglia Scritti I. Torino: Einaudi, 1981. p.xix-xxiv.

BASAGliA, Franca O. Basaglia Scritti II (1964-1980) - dall'apertura del manicomio alla nuova legge sul'assistenza psichiatrica. Torino: Einaudi, 1982.

BASAGlia, Franca O. Mario Tommasini: vidas e feitos de um democrata radical. São Paulo: Hucitec, 1993.

Basaglia, Franco \& Basaglia, Franca O. (Orgs.). Los crimenes de la paz: investigacion sobre los intelectueles y los tecnicos como servidores de la opresion. México: Siglo XXI, 1977.

Basaglia, Franco \& Basaclia, Franca O. (Orgs.). Potere ed istituzionalizzazione (dalla vita istituzionale alla vita di comunità). In: BASACLIA, Franca O. (Org.) Basaglia Scritti I. Torino: Einaudi, 1981. p.283-293. 
Basaclia, Franco \& Basaclia, Franca O. (Orgs.). Un problema di psichiatria istituzionale - l'esclusione come categoria socio-psichiatrica. In: BASAGLIA, Franca O. (Org.) Basaglia Scritti II. Torino: Einaudi, 1981. p.309-328.

Basaglia, Franco \& Basaglia, Franca O. (Orgs.). Follia/delirio. In: Basaglia, Franca O. (Org.) Basaglia Scritti II. Torino: Einaudi, 1982. p.411-444.

Basaglia, Franco \& Basaglia, Franca O. (Orgs.). Introduzione a lo Psicanalismo. In: Basaglia, Franca O. (Org.) Basaglia Scritti II. Torino: Einaudi, 1982. p.349-353.

Basaglia, Franco \& Basaglia, Franca O. (Orgs.). Crimini di pace. In: Basaglia, Franca O. (Org.) Basaglia Scritti II. Torino: Einaudi, 1982. p.237-338.

Basaglia, Franco \& Basaclia, Franca O. (Orgs.). La maggioranza deviante. In: Basaglia, Franca O. (Org.) Basaglia Scritti II. Torino: Einaudi, 1982. p.155-184.

Basaglia, Franco \& Basaglia, Franca O. (Orgs.). La malattia e il suo doppio (proposte critiche sul problema delle devianze). In: Basaclia, Franca O. (Org.) Basaglia Scritti II. Torino: Einaudi, 1982. p.126-146.

Basaglia, Franco \& Basaglia, Franca O. (Orgs.). Prefazione a Ideologia e pratica della psichiatria sociale. In: BASACLIA, Franca O. (Org.) Basaglia Scritti II. Torino: Einaudi, 1982. p.105-125.

Basaglia, Franco \& Basaglia, Franca O. (Orgs.). Prefazione a II comportamento in pubblico. In: BaSAGliA, Franca O. (Org.) Basaglia Scritti II. Torino: Einaudi, 1982. p.147-154.

Basaglia, Franco \& Gallıo, G. Vocação terapêutica e luta de classes - para uma análise crítica do modelo italiano. In: Delgado, J. (Org.) A Loucura na Sala de Jantar. Santos: edição do autor, 1991. p.27-51. 
Basaglia, Franco \& Gianichedda, M. G. Legge e psichiatria - per un'analisi delle normative nel campo psichiatrico. In: BASAGLIA, Franca O. (Org.) Basaglia Scritti II. Torino: Einaudi, 1982. p.445-466.

Basaglia, Franco \& Gianichedda, M. G. et al. II circuito del controllo: dal manicomio al decentramento psichiatrico. In: BASAGLIA, Franca O. (Org.) Basaglia Scritti II. Torino: Einaudi, 1982. p.391-408.

Basaglia, Franco \& Tranchina, P. (Orgs.). Autobiografia di un Movimento (19611979) - dal manicomio alla riforma sanitaria. Arezzo: Amministrazione Provinciale di Arezzo, 1979.

BASAGLIA, Franco. A psiquiatria alternativa - contra o pessimismo da razão o otimismo da prática. Brasil Debate (São Paulo), 1979.

Basaglia, Franco. Corpo e istituzione (considerazioni antropologiche e psicopatologiche in tema di psichiatria istituzionale). In: BASAGLIA, Franca O. (Org.) Basaglia Scritti I. Torino: Einaudi, 1981. p.428-441.

Basaglia, Franco. Crisi istituzionale o crisi psichiatrica? In: Basaglia, Franca O. (Org.) Basaglia Scritti I. Torino: Einaudi, 1981. p.442 -454.

Basaglia, Franco. Dare un nome all'oppressione. In: Basaglia, Franca O. (Org.) Basaglia Scritti I. Torino: Einaudi, 1981. p.424 -427.

BASAGliA, Franco. Esclusione, programmazione a integrazione (appunti sulla realtà psichiatrica italiana). In: BASAGLIA, Franca O. (Org.) Basaglia Scritti I. Torino: Einaudi, 1981. p.410-423.

Basaglia, Franco. II problema dell'incidente. In: Basaglia, Franca O. (Org.) Basaglia Scritti I. Torino: Einaudi, 1981. p.506-511. 
Basaclia, Franco. II problema della gestione. In: Basaclia, Franca O. (Org.) Basaglia Scritti I. Torino: Einaudi, 1981. p.512-521.

BASAGLIA, Franco. L'ideologia del corpo come espressività nevrotica (le nevrosi neurasteniche). In: BASAGLIA, Franca O. (Org.) Basaglia Scritti I. Torino: Einaudi, 1981. p.342-375.

BASAGLIA, Franco. La comunità terapeutica come base di un servizio psichiatrico - realtà i prospettive. In: BASAGliA, Franca O. (Org.) Basaglia Scritti I. Torino: Einaudi, 1981. p. 259-282.

BASAGla, Franco. La distruzione dell'ospedale psichiatrico come luogo di istituzionalizzazione (mortificazione a libertà del'spazio 'chiuso' considerazioni sul sistema 'open door'). In: BASAGLIA, Franca O. (Org.) Basaglia Scritti I. Torino: Einaudi, 1981. p.249-258.

BASAGLIA, Franco. La libertà comunitaria come alternativa alla regressione istituzionale. In: BASACLIA, Franca O. (Org.) Basaglia Scritti I. Torino: Einaudi, 1981. p.394-409.

BASAGlia, Franco. La soluzione finale. In: Basagla, Franca O. (Org.) Basaglia Scritti I. Torino: Einaudi, 1981. p.455-464.

BASAGliA, Franco. Le istituzione della violenza. In: BASAGLIA, Franca O. (Org.) Basaglia Scritti I. Torino: Einaudi, 1981. p. 471-505.

BASAGLIA, Franco. Presentazione a Che cos'è la psichiatria? In: BASAGLIA, Franca O. (Org.) Basaglia Scritti I. Torino: Einaudi, 1981. p.384-393.

BasAGliA, Franco. Presentazione a L'Istituzione negata. In: Basaclia, Franca O. (Org.) Basaglia Scritti I. Torino: Einaudi, 1981. p. 468-470. 
Basaglia, Franco. Appunti di psichiatria istituzionale. In: BasaGlia, Franca O. (Org.) Basaglia Scritti II. Torino: Einaudi, 1982. p.43-72.

BASAGLIA, Franco. Conversazione à proposito della nuova legge 180. In: BASAGLIA, Franca O. (Org.) Basaglia Scritti II. Torino: Einaudi, 1982. p.473-485.

BASAGlia, Franco. Introduzione a Asyluns. In: BASAGLIA, Franca O. (Org.) Basaglia Scritti II. Torino: Einaudi, 1982. p.33-46.

BASAGLIA, Franco. Introduzione a Morire di classe. In: BASAGlia, Franca O. (Org.) Basaglia Scritti II. Torino: Einaudi, 1982. p73-79.

BASAGlia, Franco. L'utopia della realtà. In: Basaglia, Franca O. (Org.) Basaglia Scritti II. Torino: Einaudi, 1982. p.339-348.

BASAGLIA, Franco. La comunità terapeutica a le istituzioni psichiatriche. In: BASAGLIA, Franca O. (Org.) Basaglia Scritti II. Torino: Einaudi, 1982. p.3-13.

BASAGLIA, Franco. Lettera da New York - II malato artificiale. In: BaSAGLIA, Franca O. (Org.) Basaglia Scritti II. Torino: Einaudi, 1982. p.96-104.

Basaglia, Franco. Conferenze Brasiliane. Pistoia: Psichiatria Democratica, 1983.

BASAGlia, Franco (Org.). Que es la psiquiatria? Madrid: Guadarrama, 1977.

BASAGlia, Franco. et. al. A Instituição Negada - relato de um hospital psiquiátrico. Rio de Janeiro: Graal, 1985.

BASAGlia, Franco. et. al. Considerações sobre uma experiência comunitária. In: Amarante, P. (Org.) Psiquiatria Social e Reforma Psiquiátrica. Rio de Janeiro: Ed. Fiocruz, 1994. p.11-40. 
Bercherie, P. Os Fundamentos da Clínica - história e estrutura do saber psiquiátrico. Rio de Janeiro: Zahar, 1989.

Berlinguer, G. Questioni di vita - etica, scienza, salute. Torino: Einaudi, 1991.

Bermudez, J. A. Z. Saúde e Indústria Farmacêutica: rumos e desafios. Rio de Janeiro: Ensp/Fiocruz, 1991. (Mimeo.)

Beyssade, J. M. Descartes. In: Châtelet, F. (Org.) A Filosofia do Mundo Novo. v.3., Rio de Janeiro: Zahar, 1974. p.81-114.

Bezerra, B. Cidadania e loucura: um paradoxo? In: Bezerra, B. \& Amarante, P. (Orgs.) Psiquiatria sem Hospício: contribuições ao estudo da reforma psiquiátrica. Rio de Janeiro: Relume-Dumará, 1992. p.113-126.

Bezerra, B. De médico, de louco e de todo mundo um pouco: o campo psiquiátrico no Brasil nos anos oitenta. In: Guimaräes, R. \& Tavares, R. (Orgs.) Saúde e Sociedade no Brasil anos 80. Rio de Janeiro: RelumeDumará, 1994. p.171-191.

Birman, J. A Psiquiatria como Discurso da Moralidade. Rio de Janeiro: Graal, 1978.

BIRMAN, J. Psiquiatria e sociedade. Jornal Brasileiro de Psiquiatria, 31(4):237246, 1982.

Birman, J. A cidadania tresloucada. In: Bezerra, B. \& Amarante, P. (Orgs.) Psiquiatria sem hospício - contribuições ao estudo da reforma psiquiátrica. Rio de Janeiro: Relume-Dumará, 1992. p.71-90.

BIRMAN, J. \& COSTA, J. F. Organização de instituições para uma psiquiatria comunitária. In: Amarante, P. (Org.) Psiquiatria Social e Reforma Psiquiátrica. Rio de Janeiro: Ed. Fiocruz, 1994. p.41-72. 
Boltanskı, L. As Classes Sociais e o Corpo. Rio de Janeiro: Graal, 1979.

Brandāo, J. C. T. Os Alienados no Brasil. Rio de Janeiro: Imprensa Nacional, 1886.

Brown, B. S. Desinstitucionalization and comunity support systems - statement by the director, Estados Unidos, National Institute of Mental Health, 1975.

Burton, R. Institucional Neurosis. Bristol, 1959. (Mimeo.)

Caplan, G. Princípios de Psiquiatria Preventiva. Rio de Janeiro: Zahar, 1980.

CAstel, R. A Ordem Psiquiátrica - a idade de ouro do alienismo. Rio de Janeiro: Graal, 1978a.

CAStel, R. A instituição psiquiátrica em questão. In: Ficueıra, S. A. (Org.) Sociedade e Doença Mental. Rio de Janeiro: Campus, 1978b. p.149-193.

Castel, R. O Psicanalismo. Rio de Janeiro: Graal, 1978c.

CAstel, R. A Gestão dos Riscos - da antipsiquiatria à pós-psicanálise. Rio de Janeiro: Francisco Alves, 1987.

Ceruti, M. \& Bocchi, G. Disordine e Costruzione. Milano: Feltrinelli, 1981.

Ceruti, M. \& Bocchi, G. La sfida della complessità. Milano: Feltrinelli, 1985.

Cooper, D. Psiquiatria e Antipsiquiatria. São Paulo: Perspectiva, 1973.

CoOper, D. A Linguagem da Loucura. Lisboa: Presença, 1979.

Cooper, D.; Basaglia, Franco \& Castel, R. (Orgs.). Psiquiatria e Antipsiquiatria em Debate. Porto: Afrontamento, 1977. 
CORBIIIER, R. Hegel - textos escolhidos. Rio de Janeiro: Civilização Brasileira, 1981.

Costa, J. F. Saúde mental: produto da educação? Revista Saúde em Debate, 11:59-66, 1980.

Costa, J. F. História da Psiquiatria no Brasil - um corte ideológico. 4.ed. Rio de Janeiro: Xenon, 1989.

Davrdov, J. Il lavoro e la libertà. Torino: Einaudi, 1966. In: BASAGliA, Franco. Corpo e Istituzione (considerazioni antropologiche e psicopatologiche in tema di psichiatria istituzionale), 1967.

De Leonardis, O. Decostruzione, innovazione: strategie cognitive della deistituzionalizzazione. In: AAvv. La Pratica Terapeutica tra Modello Clinico e Riproduzione Sociale. Pistoia: Cooperativa Centro Documentazione Editrice, 1987. p.248-260.

De Leonardis, O. II Terzo Escluso - le istituzioni come vincoli e come ricorse. Milano: Feltrinelli, Milano, 1990.

De Leonardis, O; Mauri, D. \& Rotelli, F. L'impresa Sociale. Milano: Anabasi, 1994.

DelGado, J. (Org.). A Loucura na Sala de Jantar. Santos: edição do autor, 1991.

Delgado, P. Projeto de Lei nº 3.657. Brasília, Câmara dos Deputados, 1989. (Mimeo.)

Deul'Acqua, G. Non ho l'arma the Uccide il Leone - storie del manicomio di Trieste.Trieste: Cooperativa Editoriale Via Gambini, 1978. 
Dell'Acqua, G. Basaglia. Trieste: s.n., 1980. (Mimeo)

Dell'Acqua, G. Curso de Atenção à Saúde Mental no Território. Rio de Janeiro, 1992. (vídeo)

Derrida, J. Entrevista. In: Filosofias - entrevistas do Le Monde. São Paulo: Ática, 1990. p.71-82.

Desviat, M. La Reforma Psiquiátrica: los problemas de la desinstitucionalización, 1990. (Mimeo.)

Elster, J. Negazione Ativva e Negazione Passiva. In: Watzlawick, P. (Org.) La Realtà Inventata. Milano: Feltrinelli, 1988. p.153-196.

Falret, J. P. Du traitement général des aliénés. In: BiRman, J. A Psiquiatria como Discurso da Moralidade. Rio de Janeiro: Graal, 1978.

Feyerabend, P. Entrevista. In: Idéias Contemporâneas - entrevistas do Le Monde. São Paulo: Ática, 1989. p.26-32.

Fleming, M. Ideologias e Práticas Psiquiátricas. Porto: Afrontamento, 1976.

Foucault, M. A Arqueologia do Saber. Petrópolis: Vozes, 1972.

Foucault, M. O Nascimento da Clínica. Rio de Janeiro: Forense Universitária, 1977.

Foucault, M. História da Loucura na Idade Clássica. São Paulo: Perspectiva, 1978.

Foucault, M. Microfísica do Poder. Rio de Janeiro: Graal, 1979. 
Frank, M. Quest-ce que c'est le Néo-Structuralisme?. Paris: Les Editions du Cerf, 1989.

Galeano, E. O Livro dos Abraços. Porto Alegre: L\&PM, 1991.

Garsonet, M. La loi des aliénés: nécessité d'une réforme. In: CASTEL, R. A Ordem Psiquiátrica, 1978.

Genil-Perrin. Histoire de l'origine et de l'evolution de l'idée de Dégénérescence en Médecine Mentale. s.I.: s.n., 1913.

Goffman, E. Manicômios, Prisões e Conventos. São Paulo: Perspectiva, 1974.

Goffman, E. Estigma: notas sobre a manipulação da identidade deteriorada. Rio de Janeiro: Zahar, 1975.

Gramscl, A. Os Intelectuais e a Organização da Cultura. Rio de Janeiro: Civilização Brasileira, 1968.

Hecel. Propedêutica filosófica. In: Corbisier, R. Hegel - textos escolhidos, 1981.

Herward, H. \& Varigas, M. Uma Antipsiquiatria? São Paulo: Melhoramentos, 1977.

Italia. A Lei 180 de 13 de maio de 1978. In: Delgado, J. (Org.) A Loucura na Sala de Jantar. Santos: edição do autor, 1991. p.116-122.

JaCQUaRD, A. L'héritage de la Liberté. Paris: Seuil, 1986.

Japiassu, H. \& Marcondes, D. Dicionário Básico de Filosofia. 2.ed. Rio de Janeiro: Zahar, 1991.

JONEs, M. A Comunidade Terapêutica. Petrópolis: Vozes, 1968. 
Kaplan, H. \& Sadock, B. Compêndio de Psiquiatria Dinâmica. Porto Alegre: Artes Médicas, 1984.

KOUPERNIK, C. (Org.). Antipsiquiatria: senso ou contra-senso? Rio de Janeiro: Zahar, 1976.

LaING, R. \& Cooper, D. Razão e Violência. Petrópolis: Vozes, 1981.

Laing, R. \& Esterson, A. Sanidade, Loucura e a Família. Belo Horizonte: Interlivros, 1979.

LaING, R. Sobre Loucos e Sãos. São Paulo: Brasiliense, 1982.

LANCETTI, A. Prevenção, preservação e progresso em saúde mental. In: LANCETTI, A. (Org.) Saúdeloucura 1. São Paulo: Hucitec, 1989. p.75-89.

Leão, E. C. Para uma Crítica da Interdisciplinaridade. Rio de Janeiro: Ensp/ Fiocruz, 1991. (Mimeo.)

Leavelt, H. \& Clark, E. G. Medicina Preventiva. São Paulo: McGraw-Hill do Brasil, 1976.

Lima Barreto, A. H. Diário do Hospício. Rio de Janeiro: Biblioteca Carioca, 1993.

Loucon, M. Desinstitucionalização da assistência psiquiátrica: uma perspectiva crítica. Physis - Revista de Saúde Coletiva, 3(2):137-164, 1993.

Machado de Assis. O alienista. In:__. Papéis Avulsos. Rio de Janeiro - Belo Horizonte: Garnier, 1989. p.17-66.

Machado, R. Por uma genealogia do poder. In: Foucault, M. Microfísica do Poder. Rio de Janeiro: Graal, 1979. p.ix-xxv. 
MaChado, R. Ciência e saber - a trajetória da arqueologia de Foucault. Rio de Janeiro: Graal, 1981.

MaChado, R. et al. Danação da Norma - medicina social e constituição da psiquiatria no Brasil. Rio de Janeiro: Graal, 1978.

Maturana, H. \& Varela, F. Autopoesis and Cognition. Boston: Reidel D., 1980.

Maturana, H. \& Varela, F. O que se observa depende do observador. In: Thompson, W. I. (Org.) Gaia - uma teoria do conhecimento. São Paulo: Gaia, 1990. p.61-76.

Maurı, D. (Org.). La Libertà ê Terapeutica? - I'esperienza psichiatrica di Trieste. Milano: Feltrinelli, 1983.

Mello Moraes, A. F. Physiologia das Paixões e Afecções. Rio de Janeiro: Dous de Dezembro, 1855.

Meyer, L. Violência e complacência: em torno da antipsiquiatria. Debate e Crítica, 6:115-130, 1975.

Moreira, J. Assistência aos epiléticos - colônias para eles. Arquivos Brasileiros de Psiquiatria, Neurologia e Ciências Afins, 1(2):167-182, 1905.

Morgado, A. \& LimA, L. A. Desinstitucionalização: suas bases e a experiência internacional. Jornal Brasileiro de Psiquiatria, 43(1):19-28, 1994.

Morin, E. O Paradigma Perdido - a natureza humana. Lisboa: Europa-América, 1985.

Mosher, L. \& Burtı, L. Psichiatria Territoriale - principi e pratica. Milano: Feitrinelli, 1991. 
MURICY, K. As desventuras da razão. In: - A Razão Cética: Machado de Assis e as questões de seu tempo. Rio de Janeiro: Cia. das Letras, 1988. p.33-49.

NıcÁcıo, F. (Org.). Desinstitucionalização. São Paulo: Hucitec, 1990.

NıCÁCIO, F. Da instituição negada à instituição inventada. In: LANCETTI, A. (Org.) Saúdeloucura 1. São Paulo: Hucitec, 1989. p.91-108.

Nietzsche, F. Assim falou Zaratustra. In: Coleção Os Pensadores - Nietzche. Rio de Janeiro, Abril Cultural, 1978a. p.225-265.

NietzsChe, F. O andarilho (Dos Poemas, 1871-1888). In: Coleção Os Pensadores - Nietzche. Rio de Janeiro, Abril Cultural, 1978b. p.404.

Nobre de Melo, A. L. Introdução à Psiquiatria. Rio de Janeiro: Odeon, 1945. [Psiquiatria. Rio de Janeiro: Atheneu, 1970. v.1]

Oliveira, J. A. De Doenças e Estruturas, ou, da Medicina a uma Antropologia: a constituição e desconstituição da nosologia psiquiátrica entre Pinel e Lacan (uma contribuição psicanalítica à fundamentação teórica da 'reforma psiquiátrica'). Rio de Janeiro: Ensp/Fiocruz, 1994. (Mimeo.)

Ortega y Gasset, J. Em Torno a Galileu - esquema das crises. Petrópolis: Vozes, 1989.

Pelbart, P. P. Da Clausura do Fora ao Fora da Clausura - loucura e desrazão. São Paulo: Brasiliense, 1989.

Pipparelli, M. Geel nel Passato e nel Presente - la terapia in famiglia delle malattie mentali attraverso $i$ secoli. Bolonha: Pàtron Editore, 1980. 
Portocarrero, V. M. Juliano Moreira e a descontinuidade histórica da psiquiatria, 1980. Dissertação de Mestrado, Rio de Janeiro: Departamento de Filosofia, Pontifícia Universidade Católica.

Portocarrero, V. M. O dispositivo da saúde mental - uma metamorfose na psiquiatria brasileira, 1990. Tese de Doutorado, Rio de Janeiro: Instituto de Filosofia e Ciências Sociais, UFRJ.

Prigogine, I. \& Stencers, I. A Nova Aliança: metamorfose da ciência. Brasília: Ed. Universidade de Brasília, 1984.

PrIGOGINE, I. Entrevista. In: Idéias contemporâneas - entrevistas do Le Monde. São Paulo: Ática, 1989. p.51-59.

RıBEIRo, R. de C. A desinstitucionalização, Rotelli e a nossa realidade. Informação psiquiátrica, 12(3):119-120, 1993.

ROSEN, G. Locura y sociedad - sociologia histórica de la enfermedad mental. Madri: Alianza Universidad, 1974.

RotelL, F. A instituição inventada. In: NICÁCıO, F. (Org.) Desinstitucionalização. São Paulo: Hucitec, 1990. p.89-99.

RotelL, F. A lei.180 e a reforma psiquiátrica italiana. In: BezerRA, B. \& Amarante, P. (Orgs.) Psiquiatria sem Hospício - contribuições ao estudo da reforma psiquiátrica. Rio de Janeiro: Relume-Dumará, 1992. p.91-97.

RotelL, F. Superando o manicômio - o circuito psiquiátrico de Trieste. In: Amarante, P. (Org.) Psiquiatria Social e Reforma Psiquiátrica. Rio de Janeiro: Ed. Fiocruz, 1994. p.149-169. 
Rotelli, F. \& Amarante, P. Reformas psiquiátricas na Itália e no Brasil - aspectos históricos e metodológicos. In: Bezerra, B. \& Amarante, P. (Orgs.) Psiquiatria sem Hospício - contribuições ao estudo da reforma psiquiátrica. Rio de Janeiro: Relume-Dumará, 1992. p.41-55.

Roteluı, F. et al. Desinstitucionalização, uma outra via. In: NıCÁcıO, F. (Org.) Desinstitucionalização. São Paulo: Hucitec, 1990. p.17-59.

RoudinesCo, E. et al. Foucault - leituras da História da Loucura. Rio de Janeiro: Relume-Dumará, 1994.

Santos, B. de S. Um Discurso sobre as Ciências. Porto: Afrontamento, 1987.

Saraceno, B. Questões abertas em psicofarmacologia clínica. In: Russo, J. \& Ferreira, J. (Orgs) Duzentos Anos de Psiquiatria. Rio de Janeiro: UFRJ/ Relume-Dumará, 1993. p.163-180.

SCABIA, G. Marco Cavallo: una esperienza di animazione in un ospedale psichiatrico. Torino: Einaudi, 1976.

Schramm, F. R. Algumas Notas sobre a Complexidade. Rio de Janeiro: Ensp/ Fiocruz, 1991. (Mimeo.)

Schramm, F. R. \& Castiel, L. D. Processo saúde-doença e complexidade em epidemiologia. Cadernos de Saúde Pública, 8(4):379-390, 1992.

SCIACCA, M. F. História da Filosofia. São Paulo: Mestre Jou, 1968. v.3.

Serres, M. Entrevista. In: Filosofias - entrevistas do Le Monde. São Paulo: Ática, 1990a. p.179-189.

Serres, M. Hermes - uma filosofia das ciências. Rio de Janeiro: Graal, 1990b. 
Sheper-Hughes, N. \& Lovell, A. M. (Orgs.). Psychiatry inside out - selected writings of Franco Basaglia. New York: Columbia University Press, 1987.

SLAVICH, A. O papel da psiquiatria democrática no contexto da psiquiatria institucional italiana. Jornal Brasileiro de Psiquiatria, 38(1):23-26, 1989.

SONENREICH, C. Visão psiquiátrica das alterações mentais. In: D'INCAO, M. A. (Org.) Doença mental e sociedade - uma visão interdisciplinar. Rio de Janeiro: Graal, 1992. p.92-107.

SPINK, M. J. P. Saúde: um campo interdisciplinar? Revista de Terapia Ocupacional da USP, 3(1/2):17-23, 1992.

Stencers, I. Quem Tem Medo das Ciências - ciências e poderes. São Paulo: Siciliano, 1990.

SZAsz, T. A Fabricação da Loucura. Rio de Janeiro: Zahar, 1976.

Szasz, T. Ideologia e Doença Mental. Rio de Janeiro: Zahar, 1980a.

Szasz, T. O Mito da Doença Mental. Rio de Janeiro: Zahar, 1980b. [originalmente publicado em 1961]

Teixeira, S. F. (Org.). Reforma Sanitária: em busca de uma teoria. São Paulo: Cortez, 1989.

TENon, J. Mémoires sur les hôpitaux de Paris. In: CASTEL, R. A Ordem Psiquiátrica, 1978.

TESTA, M. O hospital - visão desde o leito do paciente. Saúde Mental Coletiva, I(1):46-54, 1992. 
VenturinI, E. Le Parole della deistituzionalizzazione. Spazio della Mente, 2(6):3-8, 1990.

Veras, R. \& SouzA, A. L. Prevenção primária em saúde mental - reflexões e outras críticas. Abertura, 0:3-6, 1977.

Veras, R.; Schechtman, A. \& Nogueira, A. L. Um estudo teórico do modelo de prevenção psiquiátrica. Jornal Brasileiro de Psiquiatria, 25(4), 1976.

Vertzman, J.; Cavalcanti, M. T. \& Serpa Júnior., O. Psicoterapia institucional: uma revisão. In: Bezerra, B. \& Amarante, P. (Orgs.) Psiquiatria sem Hospício contribuições ao estudo da reforma psiquiátrica. Rio de Janeiro: RelumeDumará, 1992. p.17-30.

Watzlawick, P. (Org.). La Realtà Inventata. Milano: Feltrinelli, 1988.

WeBer, M. A ciência como vocação. In: . Ensaios de Sociologia. Rio de Janeiro: Zahar, 1982. p.154-183. 
Formato: $16 \times 23 \mathrm{~cm}$

Tipologia: ZapfHumanist BT, AvantGarde BK BT e Castel T

Papel: Pólen Bold $70 \mathrm{~g} / \mathrm{m}^{2}$ (miolo)

Cartão Supremo $250 \mathrm{~g} / \mathrm{m}^{2}$ (capa)

Fotolitos: Laser vegetal (miolo)

Ace Digital Ltda. (capa)

Reimpressão e acabamento: Imprinta Express Gráfica e Editora Ltda,

Rio de Janeiro, outubro de 2010

Não encontrando nossos títulos em livrarias, contactar a EDITORA FIOCRUZ:

Av. Brasil, $4036-1^{2}$ andar - sala 112 - Manguinhos

$21040-361$ - Rio de Janeiro - RJ

Tel.: (21) 3882-9007/ Telefax: (21) 3882-9006

e-mail: editora@fiocruz.br

http//www.fiocruz.br/editora 
